In cooperation with the California State Water Resources Control Board

Ground-Water Quality Data in the North San Francisco Bay Hydrologic Provinces, California, 2004: Results from the California Ground-Water Ambient Monitoring and Assessment (GAMA) Program

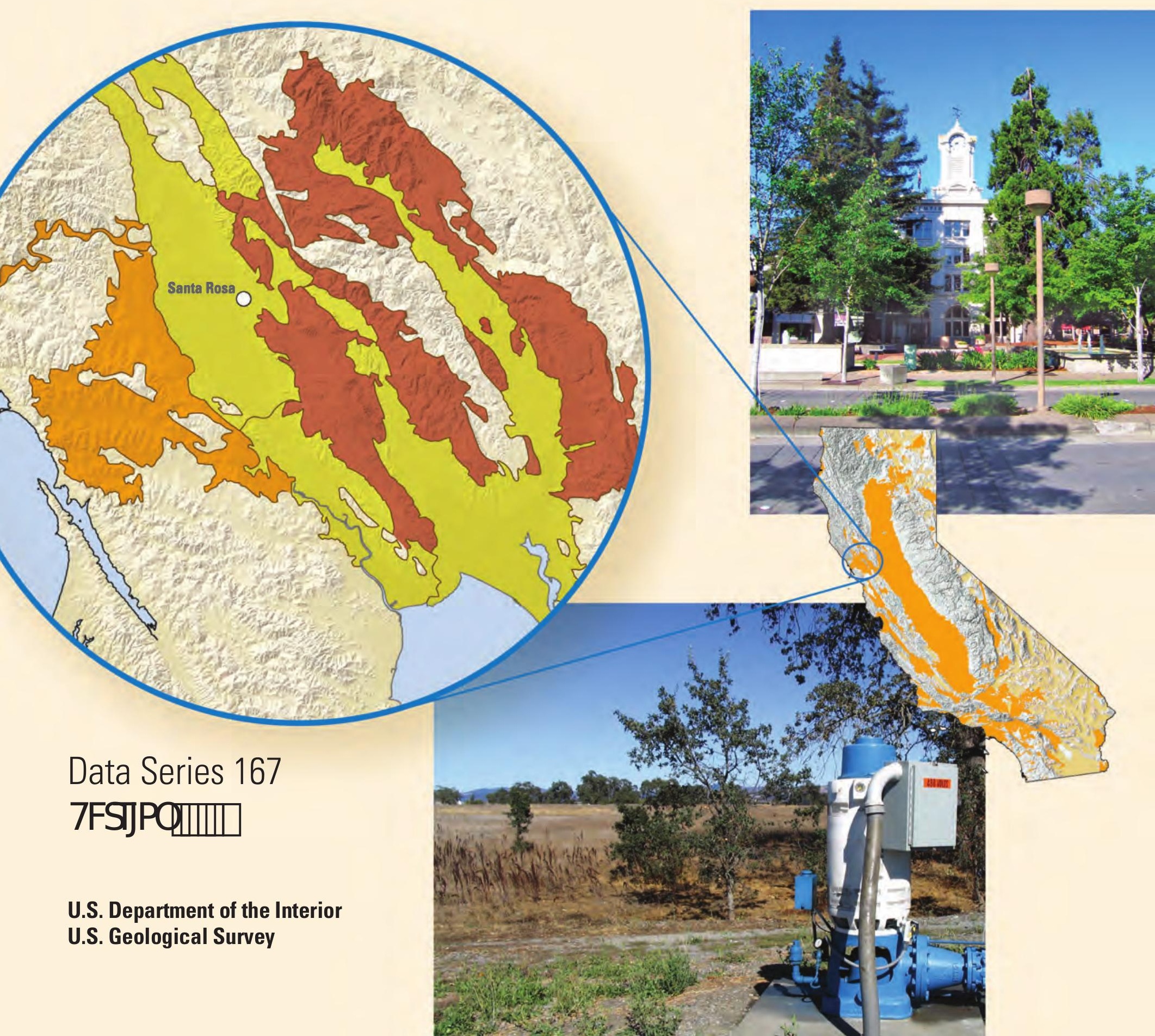




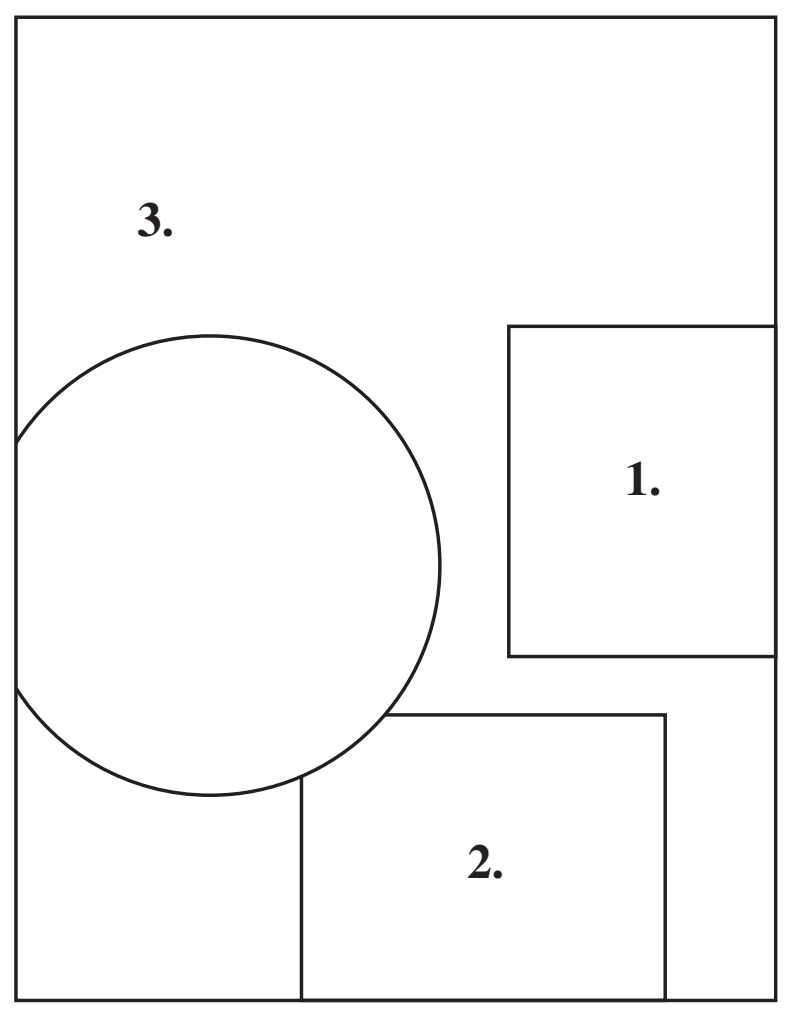

\section{Cover Credits:}

1. Photo of the Empire Building in Courthouse Square downtown Santa Rosa, California.

Photographer: Joseph Lang, Santa Rosa, California

2. Photo of a municipal supply well.

Sonoma County, California

Photographer: Tyler Johnson, USGS, California

3. Cover design and illustrations:

Laurel Rogers, San Diego, California 


\section{Ground-Water Quality Data in the North San Francisco Bay Hydrologic Provinces, California, 2004: Results from the California Ground-Water Ambient Monitoring and Assessment (GAMA) Program}

By Justin T. Kulongoski, Kenneth Belitz, and Barbara J. Dawson

In cooperation with the California State Water Resources Control Board

Data Series 167

7FSTPQIس⿴囗口 


\section{U.S. Department of the Interior \\ P. Lynn Scarlett, Acting Secretary}

\section{U.S. Geological Survey \\ P. Patrick Leahy, Acting Director}

U.S. Geological Survey, Reston, Virginia: 2006

Revised: 2011

For product and ordering information:

World Wide Web: http://www.usgs.gov/pubprod

Telephone: 1-888-ASK-USGS

For more information on the USGS--the Federal source for science about the Earth, its natural and living resources, natural hazards, and the environment:

World Wide Web: http://www.usgs.gov

Telephone: 1-888-ASK-USGS

Any use of trade, product, or firm names is for descriptive purposes only and does not imply endorsement by the U.S. Government.

Although this report is in the public domain, permission must be secured from the individual copyright owners to reproduce any copyrighted materials contained within this report.

Suggested citation:

Kulongoski, J.T., Belitz, Kenneth, and Dawson, B.J., 2006, Ground-water quality data in the North San Francisco Bay hydrologic provinces, California, 2004: Results from the California Ground-Water Ambient Monitoring and Assessment (GAMA) Program: U.S. Geological Survey Data Series Report 167, 100 p. 


\section{Contents}

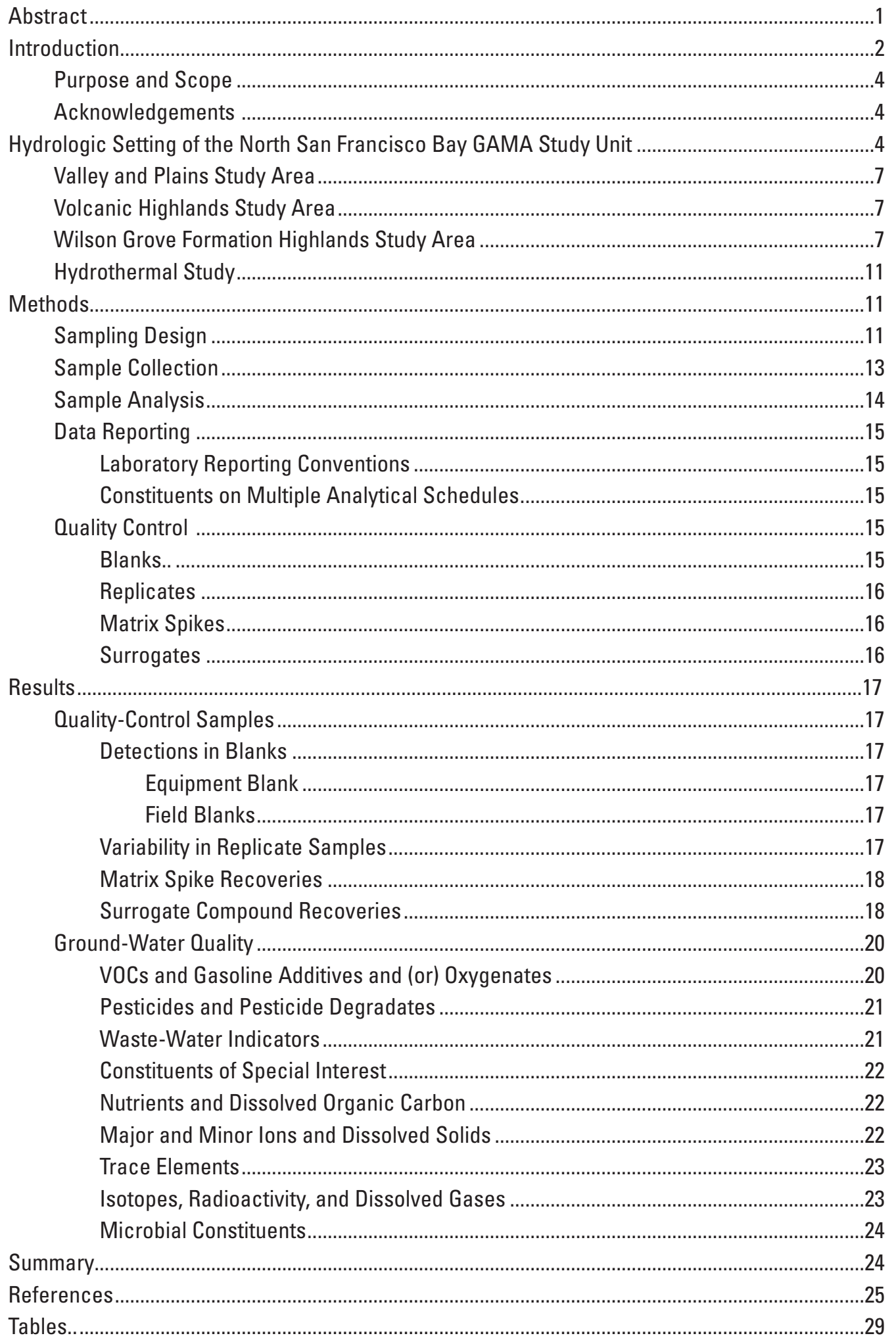




\section{Figures}

Figure 1. Map showing the 10 hydrologic provinces considered for the California GAMA study, with the North San Francisco Bay study unit outlined.

Figure 2. Maps showing the North San Francisco Bay GAMA study unit, locations of study areas, major cities, rivers, ground-water basins and subbasins, target wells, and 10-square-mile randomized sampling grid cells.

Figure 3. Map showing the Valley and Plains study area with the locations of the randomized public-supply wells and flow-path wells sampled for the North San Francisco Bay GAMA study, California.

Figure 4. Map showing the Volcanic Highlands study area randomized sampling grid cells and locations of the randomized public-supply wells sampled for the North San Francisco Bay GAMA study, California.

Figure 5. Map showing the Wilson Grove Formation Highlands study area, the randomized sampling grid cells, and the locations of the randomized public-supply wells and flow path well sampled for the North San Francisco Bay GAMA study, California.

Figure 6. Map showing the hydrothermal study wells and spring sampled for the North San Francisco Bay GAMA study, California.

\section{Tables}

Table 1. Identification, sampling and construction information for wells sampled for the North San Francisco Bay Ground-Water Ambient Monitoring and Assessment (GAMA) study, California, August to November 2004.

Table 2A. Volatile organic compounds and gasoline additives and (or) oxygenates, primary use or source, Chemical Abstract Service (CAS) number, and laboratory reporting level (LRL) for the U.S. Geological Survey's National Water Quality Laboratory analytic schedule 2020.

Table 2B. Gasoline oxygenates and (or) gasoline oxygenate degradates, primary use or source, Chemical Abstract Service (CAS) number, and laboratory reporting level (LRL) for the U.S. Geological Survey's National Water Quality Laboratory analytical schedule.

Table 2C. Pesticides and pesticide degradates, primary use or source, Chemical Abstract Service (CAS) number, and laboratory reporting level (LRL) for the U.S. Geological Survey's National Water Quality Laboratory analytical schedule 2003

Table 2D. Pesticides, pesticide degradates and caffeine, primary use or source, Chemical Abstract Service (CAS) number, and laboratory reporting level (LRL) for the U.S. Geological Survey's National Water Quality Laboratory analytical schedule 2060.

Table 2E. Waste-water indicator constituents, primary use or source, Chemical Abstract Service (CAS) number, and laboratory reporting level (LRL) for the U.S. Geological Survey's National Water Quality Laboratory analytical schedule 1433 
Table 2F. Constituents of special interest: perchlorate, 1,2,3-tricholoropropane, and $\mathrm{N}$-nitrosodimethylamine (NDMA), Chemical Abstract Service (CAS) number, and minimum reporting level (MRL) for Montgomery Watson Harza Laboratory............42

Table 2G. Nutrients and dissolved organic carbon, Chemical Abstract Service (CAS) number, and laboratory reporting level (LRL) for the U.S. Geological Survey's National Water Quality Laboratory analytical schedule 2755 and laboratory code 2613.

Table 2H. Major and minor ions and trace elements, Chemical Abstract Service (CAS) number, and laboratory reporting level (LRL) for the U.S. Geological Survey's National Water Quality Laboratory analytical schedule 1948.

Table 2I. Iron, arsenic and chromium speciation, Chemical Abstract Service (CAS) number, and method detection limit (MDL) for the U.S. Geological Survey's National Research Program Laboratory, Boulder, Colorado...

Table 2J. Isotopic and radioactive constituents, Chemical Abstract Service (CAS) number, reporting level type, reporting level and (or) uncertainty, and reporting units for the U.S. Geological Survey's National Water Quality Laboratory, Stable Isotope and Tritium Laboratory, Menlo Park, California', Stable Isotope Laboratory, Reston, Virginia ${ }^{2}$, and the contract laboratories Eberline Analytical Services ${ }^{3}$ and the University of Arizona, Accelerator Mass Spectrometry Laboratory ${ }^{4}$.

Table 2K. Tritium and dissolved gases, Chemical Abstract Service (CAS) number, method uncertainty (MU) and reporting units for Lawrence Livermore National Laboratory.

Table 2L. Microbial constiuents, primary use and source, and method detection limit (MDL) for the U.S. Geological Survey's Ohio Microbiology Laboratory parameter codes $90901,90900,99335$ and 99332

Table 3. Classes of chemical and microbial constituents and water-quality indicators collected for the expanded, basic-plus, basic, and hydrothermal sampling schedules for the North San Francisco Bay Ground-Water Ambient Monitoring and Assessment (GAMA) study, California, August to November, 2004.

Table 4. Constituents analyzed in ground-water samples collected for the North San Francisco Bay Ground-Water Ambient Monitoring and Assessment (GAMA) study, that appear on multiple analytical schedules, primary constituent classification, analytical schedules constituent appears on, and preferred analytical schedule

Table 5. Quality-control summary for volatile organic compounds and gasoline additives and (or) oxygenates, pesticides and (or) pesticide degradates, waste-water indicators, major and minor ions, trace elements, and nutrients and dissolved organic carbon, detected in equipment blanks, field blanks and ground-water samples collected for the North San Francisco Bay Ground-Water Ambient Monitoring and Assessment (GAMA) study, California, August to November 2004

Table 6A. Quality-control summary of replicate volatile organic compound (VOC) and gasoline additives and (or) oxygenates, pesticides and (or) pesticide degradates, waste-water indicators, and samples for constituents of special interest with relative standard deviations greater than zero, collected for the North San Francisco Bay Ground-Water Ambient Monitoring and Assessment (GAMA) study, Calfiornia, August to November 2004 
Table 6B. Quality-control summary of replicate nutrient and dissolved organic carbon samples collected for the North San Francisco Bay Ground-Water Ambient Monitoring and Assessment (GAMA) study, California, August to November 2004.

Table 6C. Quality-control summary of replicate major and minor ion samples collected for the North San Francisco Bay Ground-Water Ambient Monitoring and Assessment (GAMA) study, California, August to November 2004.

Table 6D. Quality-control summary of replicate trace-element samples collected for the North San Francisco Bay Ground-Water Ambient Monitoring and Assessment (GAMA) study, California, August to November 2004. .51

Table 6E. Quality-control summary of replicate isotope and radioactivity samples collected for the North San Francisco Bay Ground-Water Ambient Monitoring and Assessment (GAMA) study, California, August to November 2004.

Table 7A. Quality-control summary of volatile organic compounds (VOCs), gasoline additives and oxygenates, NDMA and 1,2,3-trichloropropane matrix spike recoveries in samples collected for the North San Francisco Bay GroundWater Ambient Monitoring and Assessment (GAMA) study, California, August to November 2004.

Table 7B. Quality-control summary of matrix pesticide spike recoveries in samples collected for the North San Francisco Bay Ground-Water Ambient Monitoring and Assessment (GAMA) study, California, August to November 2004.

Table 7C. Quality-control summary of matrix waste-water indicators spike recoveries in samples collected for the North San Francisco Bay Ground-Water Ambient Monitoring and Assessment (GAMA) study, California, August to November 2004.

Table 8. Summary of surrogate recoveries for ground-water and quality-control analyses of volatile organic compounds, gasoline additives and (or) oxygenates, pesticides and (or) pesticide degradates, waste-water indicators, and constituents of special interest in samples collected for the North San Francisco Ground-Water Ambient Monitoring and Assessment (GAMA) study, California, August to November 2004

Table 9. Water-quality indicators determined in the field for the North San Francisco Bay Ground-Water Ambient Monitoring and Assessment (GAMA) study, California, August to November 2004.

Table 10A. Results of analyses for volatile organic compounds (VOCs) and gasoline additives and (or) oxygenates in ground-water samples collected in the Valley and Plains study area of the North San Francisco Bay Ground-Water Ambient Monitoring and Assessment (GAMA) study, California, August to November 2004

Table 10B. Results of analyses for volatile organic compounds (VOCs) and gasoline additives and (or) oxygenates in ground-water samples collected in the Volcanic Highlands study area of the North San Francisco Bay GroundWater Ambient Monitoring and Assessment (GAMA) study, California, August to November 2004

Table 10C. Results of analyses for volatile organic compounds (VOCs) and gasoline additives and (or) oxygenates in ground-water samples collected in the Wilson Grove Formation Highlands study area of the North San Francisco Bay Ground-Water Ambient Monitoring and Assessment (GAMA) study, California, August to November 2004 
Table 11A. Pesticides and (or) pesticide degredates detected in ground-water samples collected in the Valley and Plains study area of the North San Francisco Bay Ground-Water Ambient Monitoring and Assessment (GAMA) study, California, August to November 2004.

Table 11B. Pesticides and (or) pesticide degredates detected in ground-water samples collected in the Volcanic Highlands study area of the North San Francisco Bay Ground-Water Ambient Monitoring and Assessment (GAMA) study, California, August to November 2004

Table 11C. Pesticides and (or) pesticide degradates detected in ground-water samples collected in the Wilson Grove Formation Highlands study area of the North San Francisco Bay Ground-Water Ambient Monitoring and Assessment (GAMA) study, California, August to November 2004 ...

Table 12A. Waste-water indicators measured in ground-water samples collected in the Valley and Plains study area of the North San Francisco Bay GroundWater Ambient Monitoring and Assessment (GAMA) study, California, August to November 2004.

Table 12B Waste-water indicators measured in ground-water samples collected in the Volcanic Highlands study area of the North San Francisco Bay Ground- Water Ambient Monitoring and Assessment (GAMA) study, California, August to November 2004

Table 12C. Waste-water indicators measured in ground-water samples collected in the Wilson Grove Formation Highlands study area of the North San Francisco Bay Ground-Water Ambient Monitoring and Assessment (GAMA) study, California, August to November 2004.

Table 13. Results of analyses for the constituents of special interest: perchlorate, trichloropropane (1,2,3-TCP), N-nitrosodimethylamine (NDMA) in groundwater samples collected for the North San Francisco Bay Ground-Water Ambient Monitoring and Assessment (GAMA) study, California, August to November 2004

Table 14. Nutrients and dissolved organic carbon in ground-water samples collected for the North San Francisco Bay Ground-Water Ambient Monitoring and Assessment (GAMA) study, California, August to November 2004

Table 15. Major and minor ions and dissolved solids in ground-water samples collected for the North San Francisco Bay Ground-Water Ambient Monitoring and Assessment (GAMA) study, California, August to November 2004.

Table 16. Trace elements in ground-water samples collected for the North San Francisco

Bay Ground-Water Ambient Monitoring and Assessment (GAMA) study, California, August to November 2004.

Table 17. Inorganic arsenic and iron-speciation results measured at the U.S. Geological Survey National Research Program in ground-water samples collected for the North San Francisco Bay Ground-Water Ambient Monitoring and Assessment (GAMA) study, California, August to November 2004 ...

Table 18. Chromium-speciation results measured by the U.S. Geological Survey National Research Progam for ground-water samples collected for the North San Francisco Bay Ground-Water Ambient Monitoring and Assessment (GAMA) study, California, August to November 2004

Table 19. Isotopes and radioactivity measured in ground-water samples collected for the North San Francisco Bay Ground-Water Ambient Monitoring and Assessment (GAMA) study, California, August to November 2004. 
Table 20. Tritium and noble gas results, analyzed at the Lawrence Livermore National Laboratory for samples collected for the North San Francisco Bay GroundWater Ambient Monitoring and Assessment (GAMA) study, California, August to November 2004.

Table 21. Concentrations of the dissolved gases: carbon dioxide, nitrogen, argon, oxygen, and methane analyzed at Lawrence Livermore National Laboratory in samples collected for the North San Francisco Bay Ground-Water Ambient Monitoring and Assessment (GAMA) study, California, August to November 2004 ......

Table 22. Microbial analyses of ground-water samples collected for the North San Francisco Bay Ground-Water Ambient Monitoring and Assessment (GAMA) study, California, August to November 2004.

\section{Conversion Factors, Abbreviations, and Acronyms}

\begin{tabular}{|c|c|c|}
\hline Multiply & By & To obtain \\
\hline \multicolumn{3}{|c|}{ Length } \\
\hline inch (in.) & 2.54 & centimeter $(\mathrm{cm})$ \\
\hline foot $(\mathrm{ft})$ & 0.3048 & meter $(\mathrm{m})$ \\
\hline mile (mi) & 1.609 & kilometer $(\mathrm{km})$ \\
\hline \multicolumn{3}{|c|}{ Area } \\
\hline square mile $\left(\mathrm{mi}^{2}\right)$ & 259.0 & hectare (ha) \\
\hline square mile $\left(\mathrm{mi}^{2}\right)$ & 2.590 & square kilometer $\left(\mathrm{km}^{2}\right)$ \\
\hline
\end{tabular}

\begin{tabular}{lcl}
\hline \multicolumn{1}{c}{ Multiply } & By & \multicolumn{1}{c}{ To obtain } \\
\hline & Length & \\
\hline kilometer $(\mathrm{km})$ & 0.6214 & mile $(\mathrm{mi})$ \\
\hline square kilometer $\left(\mathrm{km}^{2}\right)$ & Area & \\
square kilometer $\left(\mathrm{km}^{2}\right)$ & 247.1 & acre \\
& 0.3861 & square mile $\left(\mathrm{mi}^{2}\right)$ \\
\hline liter $(\mathrm{L})$ & Volume & \\
liter $(\mathrm{L})$ & 33.82 & ounce, fluid $(\mathrm{fl} . \mathrm{oz})$ \\
liter $(\mathrm{L})$ & 0.2642 & gallon $(\mathrm{gal})$ \\
\hline & 61.02 & cubic inch (in $\left.{ }^{3}\right)$ \\
\hline millimeter $(\mathrm{mm})$ of mercury at $60^{\circ} \mathrm{F}$ & Pressure & \\
(in Hg) & 0.1333 & kilopascal $(\mathrm{kPa})$ \\
\hline & & \\
\hline picocurie per liter $(\mathrm{pCi} / \mathrm{L})$ & Radioactivity & \\
\hline
\end{tabular}


Temperature in degrees Fahrenheit $\left({ }^{\circ} \mathrm{F}\right)$ may be converted to degrees Celsius $\left({ }^{\circ} \mathrm{C}\right)$ as follows:

${ }^{\circ} \mathrm{C}=\left({ }^{\circ} \mathrm{F}-32\right) / 1.8$

Specific conductance is given in microsiemens per centimeter at 25 degrees Celsius $(\mu \mathrm{S} / \mathrm{cm}$ at $\left.25^{\circ} \mathrm{C}\right)$.

Concentrations of chemical constituents in water are given either in milligrams per liter (mg/L) or micrograms per liter $(\mu \mathrm{g} / \mathrm{L})$

\section{Abbreviations and Acronyms}

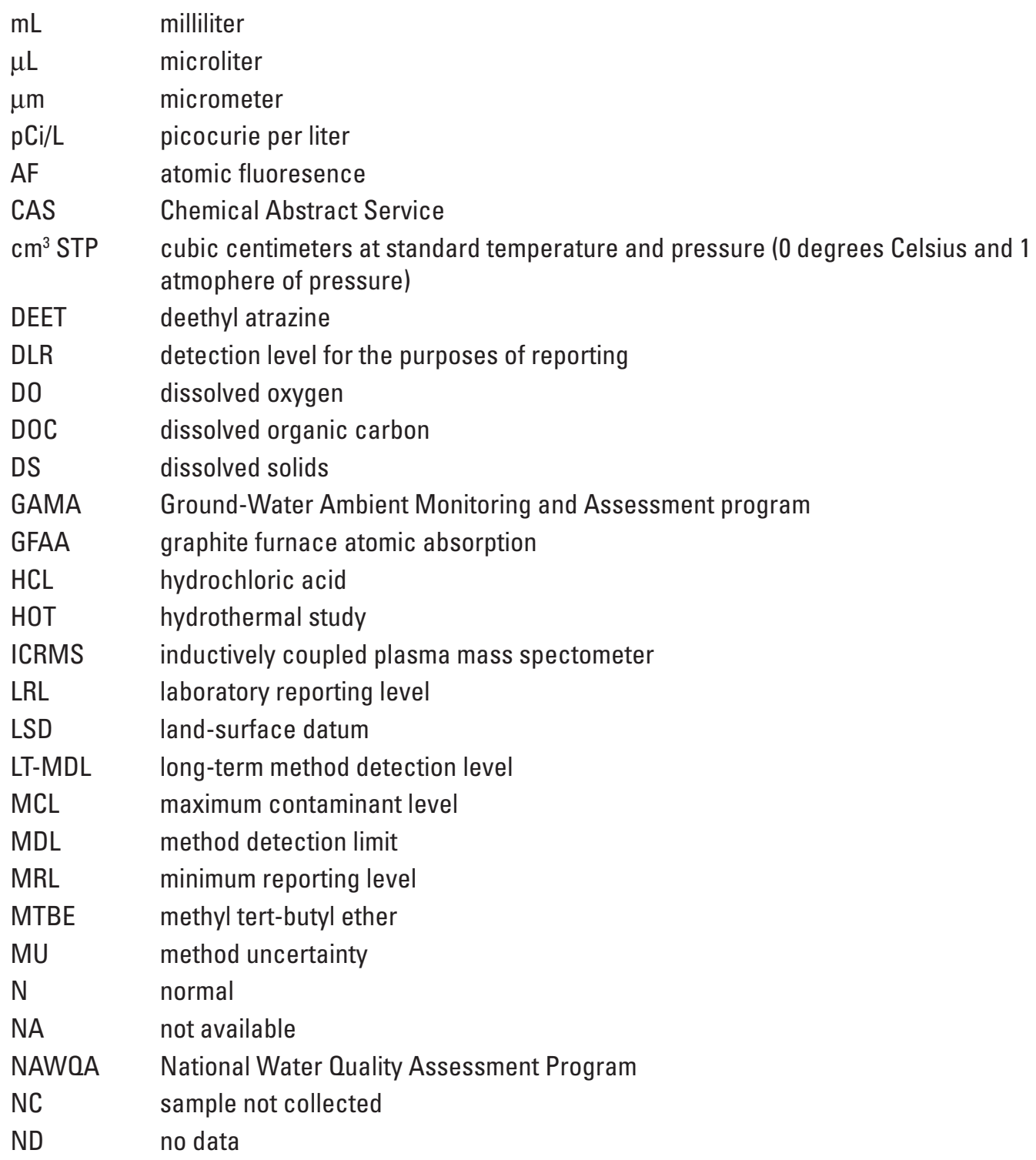




$\begin{array}{ll}\text { NDMA } & \text { N-nitrosodimethylamine } \\ \text { NL } & \text { notification level } \\ \text { NRP } & \text { National Research Program } \\ \text { NSF } & \text { North San Francisco Bay } \\ \text { NSFHOT } & \text { North San Francisco Bay Study Unit, hydrothermal study } \\ \text { NSFVOL } & \text { North San Francisco Bay Study Unit, Volcanic Highlands study area } \\ \text { NSFVP } & \text { North San Francisco Bay Study Unit, Valley and Plains study area } \\ \text { NSFVPFP } & \text { North San Francisco Bay Study Unit, Valley and Plains flow-path well } \\ \text { NSFWG } & \text { North San Francisco Bay Study Unit, Wilson Grove Formation Highlands } \\ & \text { study area } \\ \text { NSFWGFP } & \text { North San Francisco Bay Study Unit, Wilson Grove Formation Highlands } \\ & \text { flow-path well } \\ \text { NWIS } & \text { National Water Information System } \\ \text { PCE } & \text { tetrachloroethylene } \\ \text { OC } & \text { quality control } \\ \text { RSD } & \text { relative standard deviation } \\ \text { SC } & \text { specific conductance } \\ \text { SSMDC } & \text { sample specific minimum detectable concentration } \\ \text { SMCL } & \text { secondary maximum contaminant level } \\ \text { TCA } & 1,1,1,- \text { trichloroethane } \\ \text { TCE } & \text { trichloroethylene } \\ \text { TCP } & \text { trichloropropane } \\ \text { THM } & \text { trihalomethane } \\ \text { UCMR } & \text { unregulated chemical for which monitoring is required } \\ \text { VP } & \text { Valley and Plains study area } \\ \text { VOC } & \text { volatile organic compound } \\ \text { VOL } & \text { Volcanic Highlands study area } \\ \text { WG } & \text { Wilson Grove Formation Highlands study area } \\ \end{array}$

\section{Organizations}

DHS California Department of Health Services

LLNL Lawrence Livermore National Laboratory

NWOL National Water Quality Laboratory

USEPA U.S. Environmental Protection Agency

USGS U.S. Geological Survey 


\title{
Ground-Water Quality Data in the North San Francisco Bay Hydrologic Provinces, California, 2004: Results from the California Ground-Water Ambient Monitoring and Assessment (GAMA) Program
}

\author{
By Justin T. Kulongoski, Kenneth Belitz, and Barbara J. Dawson
}

\section{Abstract}

Ground-water quality in the $\sim 1,000$ square-mile $\left(\mathrm{mi}^{2}\right)$ North San Francisco Bay study unit was investigated from August to November, 2004, as part of the California Groundwater Ambient Monitoring and Assessment (GAMA) program. Samples were collected from 89 public-supply wells, 7 hydrothermal wells, and 1 hydrothermal spring in Napa, Sonoma and Marin Counties. Eighty-four of the public-supply wells sampled were selected to provide a spatially distributed, randomized monitoring network for statistical calculations and constituent detection frequency. The study was designed to provide a spatially-unbiased assessment of raw ground-water quality within the study unit, as well as a statistically-consistent basis for comparing the water quality of different study units.

Ground-water samples were analyzed for major and minor ions, trace elements, nutrients, volatile organic compounds, pesticides and pesticide degradates, waste-water indicators, dissolved methane, nitrogen, carbon dioxide and noble gases (in collaboration with Lawrence Livermore National Laboratory). Naturally occurring isotopes (tritium, carbon-14, oxygen-18, deuterium and helium-4) also were measured in the samples to help identify the source and age of the ground water. Results show that no anthropogenic constituents were detected at concentrations higher than those levels set for regulatory purposes, and relatively few naturally-occurring constituents were detected at concentrations greater than regulatory levels.
In this study, 21 of the 88 volatile organic compounds (VOCs) and gasoline additives and (or) oxygenates investigated were detected in ground-water samples, however, detected concentrations were one-half to one-forty-thousandth the maximum contaminant levels (MCL). Thirty-two percent of the randomized wells sampled had at least a single detection of a VOC or gasoline additive and (or) oxygenate. The most frequently detected compounds were chloroform, found in 12 of the 84 randomized wells; carbon disulfide, found in 8 of the 84 randomized wells; and toluene, found in 4 of the 84 randomized wells. Trihalomethanes were the most frequently detected class of VOCs.

Nine of the 122 pesticides and (or) pesticide degradates investigated were detected in ground-water samples, however, concentrations were one-seventieth to one-eight-hundredth the MCLs. Seventeen percent of the randomized wells sampled had at least a single detection of pesticide and pesticide degradate. Herbicides were the most frequently detected class of pesticides. The most frequently detected compound was simazine, found in 8 of the 84 of the randomized wells. Chlordiamino-s-triazine and deisopropyl atrazine were both found in 2 of the 84 randomized wells sampled.

Thirteen out of 63 compounds that may be indicative of the prescence of waste-water were detected in ground-water samples. Twenty-six percent of the randomized wells sampled for waste-water indicators had at least one detection. Isophorone was the most frequently detected in 6 of the 84 randomized wells. Bisphenol-A, caffeine, and indole each were detected in 3 of the 84 randomized wells. 
Major and minor ions and dissolved solids (DS) samples were collected at 33 public-supply wells; 3 samples had DS concentrations above the secondary maximum contaminant level (SMCL) of $500 \mathrm{mg} / \mathrm{L}$. Ground-water samples from 32 public-supply wells were analyzed for trace elements. Arsenic concentrations above the MCL of $10 \mu \mathrm{g} / \mathrm{L}$ were measured at 4 public-supply wells, boron concentrations above the detection level for the purpose of reporting (DLR) of $100 \mu \mathrm{g} / \mathrm{L}$ were measured at 19 wells. Iron concentrations above the SMCL of $300 \mu \mathrm{g} / \mathrm{L}$ were measured at 7 wells, a lead concentration above the California notification level (NL) of $15 \mu \mathrm{g} / \mathrm{L}$ at one well, and manganese concentrations above the SMCL of 50 $\mu \mathrm{g} / \mathrm{L}$ were measured at 17 wells. Vanadium concentrations above the DLR of $3 \mu \mathrm{g} / \mathrm{L}$ were measured at 9 public-supply wells; and chromium(VI) concentrations above the DLR of 1 $\mu \mathrm{g} / \mathrm{L}$ were measured at 48 public-supply wells.

Radon-222 was detected in all 21 ground-water samples collected, with activities ranging from 210 to 1,500 picocuries per liter $(\mathrm{pCi} / \mathrm{L})$. Fifteen radon samples were above the proposed MCL of $300 \mathrm{pCi} / \mathrm{L}$.

Microbial constituents were analyzed in 22 ground-water samples. Total coliform was detected in three wells. Counts ranged from 2 colonies per $100 \mathrm{~mL}$ to 20 colonies per $100 \mathrm{~mL}$. MCLs for microbial constituents are based on reoccurring detection, and will be monitored during future sampling.

\section{Introduction}

To assess the quality of ground water from publicsupply wells and establish a program for monitoring trends in ground-water quality, the U.S. Geological Survey (USGS) in collaboration with the State Water Board and Lawrence Livermore National Laboratory (LLNL), implemented a statewide ground-water-quality monitoring and assessment program (http://ca.water.usgs.gov/gama). The USGS developed a comprehensive approach for this effort (Belitz and others, 2003; http://water.usgs.gov/pubs/wri/wri034166/). The ground-water ambient monitoring and assessment (GAMA) program is a comprehensive assessment of statewide ground-water quality designed to help better understand and identify risks to ground-water resources. The assessment is based on groundwater samples collected at many locations across California in order to characterize their constituents and identify trends in ground-water quality. The results of these tests provide information for water agencies to address a variety of issues ranging in scale from local water supply to statewide resource management.
The GAMA program was developed in response to the Ground-Water Quality Monitoring Act of 2001 (CAL. WATER $\S \S 10780-10782.3$ ): a public mandate to assess and monitor the quality of ground water used as public supply by municipalities in California. The goal of the Ground-Water Quality Monitoring Act of 2001 is to improve statewide ground-water monitoring and facilitate the availability of information about ground-water quality to the public.

The three main objectives of GAMA are (1) status, to assess the current quality of the ground-water resource, (2) trends, to detect changes in ground-water quality and (3) understanding, to identify the natural and human factors affecting ground-water quality (Kulongoski and Belitz, 2004). This report will assess the quality of the ground-water resource, objective (1), while subsequent interpretive reports will address the trends and understanding listed in objectives (2) and (3).

The GAMA program is unique because the data collected during the study include analyses for chemical constituents that are not normally available; these data will be especially useful for providing an early indication of potential changes in water quality. Additionally, the GAMA program will analyze a broader suite of constituents, at detection limits that are lower than those currently required by the California Department of Health Services (DHS). An understanding of these factors is important for the long term management and protection of ground-water resources.

The range of hydrologic, geologic, and climatic conditions that exist in California must be considered in an unbiased assessment of ground-water quality (Belitz and others, 2003). To accomplish this, the state was partitioned into 10 hydrogeologic provinces that have relatively similar hydrologic, geologic, and climatic characteristics (fig. 1). Each of these hydrologic provinces contains ground-water basins, which are generally composed of relatively permeable, unconsolidated deposits of alluvial or volcanic origin (California Department of Water Resources, 2003). For the purpose of designing a state-wide ground-water assessment program, ground-water basins were prioritized (for sampling) based upon the number of public-supply wells in the basin (Belitz and others, 2003). Secondary consideration was given to municipal ground-water use, agricultural pumping, the number of leaking underground fuel tanks, and pesticide application within a basin. Similar adjacent ground-water basins were then combined and designated as GAMA study units. The North San Francisco Bay GAMA study unit contains 7 ground-water basins considered high priority based on the number of public-supply wells, location, agricultural use, and pesticide applications within each basin (Belitz and others, 2003). 


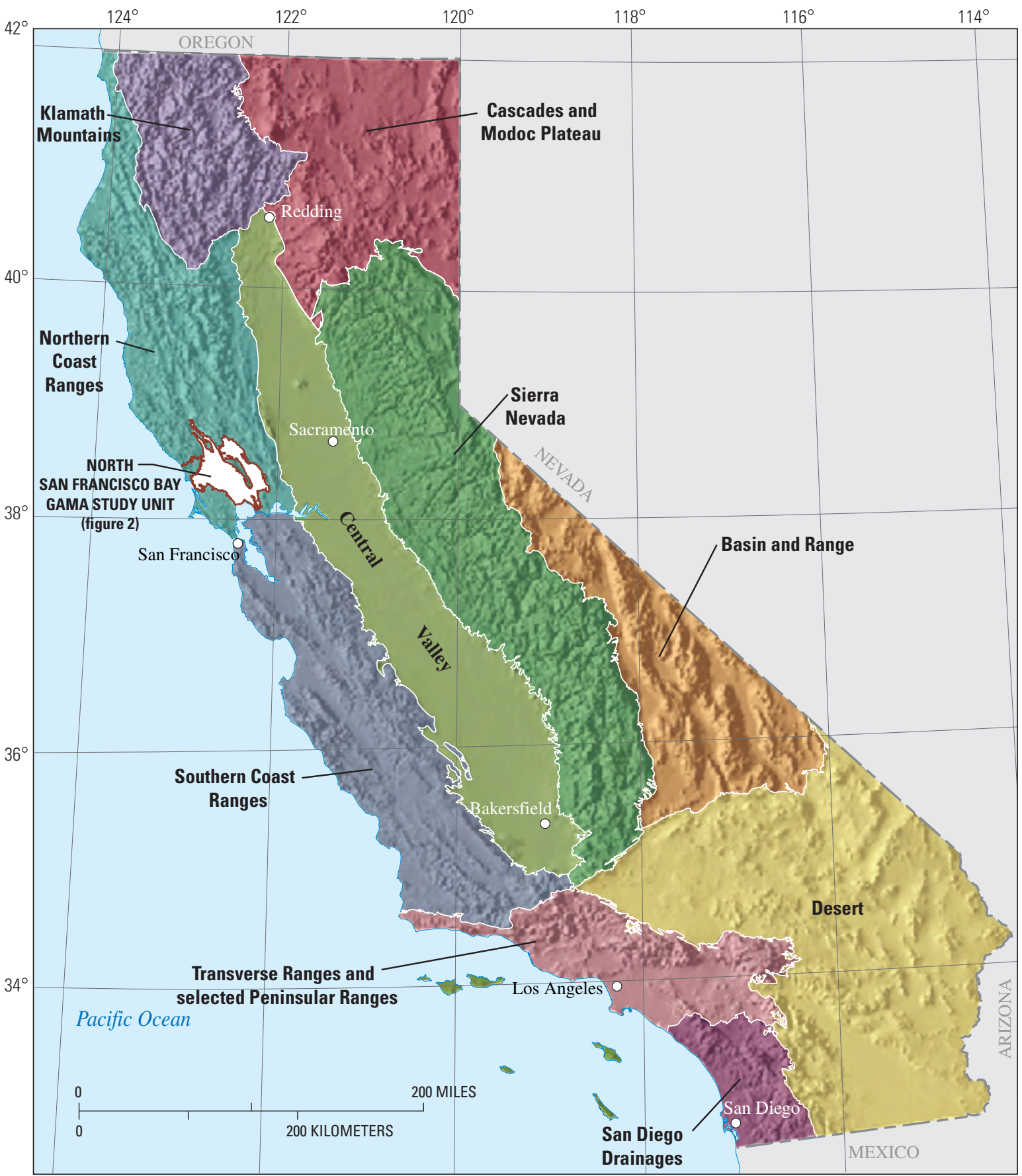

Base from U.S Geological Survey digital elevation data 1999, Albers Equal Area Projection

Figure 1. The 10 hydrologic provinces considered for the California GAMA study (Belitz and others, 2003), with the North San Francisco Bay study unit outlined. 


\section{Purpose and Scope}

The purpose of this report is to present the results of analyses for organic and inorganic constituents, microbial constituents, and general water-quality indicators from raw ground-water samples collected in the North San Francisco Bay GAMA study unit. Discussions of the factors that influence the distribution and occurrence of the compounds and microbial constituents detected in ground-water samples will be the subject of subsequent publications.

The concentrations of constituents detected in ground water sampled for this study were evaluated on the basis of state and federal drinking water regulatory standards, and constituents with concentrations greater than either primary (MCL), secondary maximum contaminant levels (SMCL), and California notification levels (NL) were identified. MCLs are established with regards to the protection of human health, whereas SMCLs are established with regards to the aesthetic qualities of drinking water such as taste, odor, and color. In addition, detections of constituents classified by DHS as "unregulated chemicals for which monitoring is required" (UCMR) were identified if concentrations in ground water were above the "detection level for the purposes of reporting" (DLR). The DLR is used for reporting constituents on the UCMR list because MCLs have not been established for these constituents. It is important to note that raw ground-water quality in this report does not indicate drinking-water quality because raw water commonly is treated or blended in order to improve water quality. In addition, an MCL violation is not determined from a single sample, but from a suite of samples with concentrations above the regulatory value. Also, ground water samples collected from hydrothermal wells and springs were excluded from regulatory water-quality discussions because these wells are not used for public drinking-water supply.

Detection frequencies were reported for the VOCs, pesticides and pesticide degradates, and waste-water indicators detected in at least one ground-water sample. Frequently detected constituents are useful in determining future trends in ground-water quality. Also presented in this report are the results and analysis of quality-control samples collected during the North San Francisco Bay GAMA study.

\section{Acknowledgements}

The authors thank the following cooperators for their support: California Water Boards, California Department of Health Services, California Department of Water Resources, and Lawrence Livermore National Laboratory.
We also thank the cooperating well owners and water purveyors for their generosity in allowing the USGS to collect samples from their wells. We thank Michael T. Wright for his assistance in organizing this report.

\section{Hydrologic Setting of the North San Francisco Bay GAMA Study Unit}

\author{
The North San Francisco Bay GAMA study unit
} (figs. 1,2) covers approximately $1,000 \mathrm{mi}^{2}$ in Napa, Sonoma and Marin Counties across Northern California. It lies within two hydrologic provinces, the San Francisco Bay and North Coast Hydrologic Provinces, as defined by the California Department of Water Resources (California Department of Water Resources, 2003). The NSF study unit includes 7 ground-water basins; the Napa-Sonoma Valley, Kenwood Valley, Alexander Valley, Santa Rosa Valley, Petaluma Valley, Wilson Grove Formation Highlands, Volcanic Highlands, and the Lower Russian River Valley (fig. 2A).

The climate in the North San Francisco Bay study unit is characterized by warm, dry summers and cool, moist winters. At the National Climate Data Center station in Sonoma, the average annual temperature is $59^{\circ} \mathrm{F}$, and the average annual precipitation is 30 inches (in.), occurring as rain during the winter and early spring. However, the distribution of precipitation across the study area is dependent upon the topography and the prevailing winds, with an increase in precipitation concomitant to an increase in altitude, and most of the rain arriving with southwesterly winds (Faye, 1973).

The study area ground-water basins are drained by several rivers and their principal tributaries including the NapaSonoma and Kenwood Valleys by the Napa River and Sonoma Creek, respectively; the Petaluma Valley by the Petaluma River; the Santa Rosa, Alexander, and Lower Russian River Valleys by the Laguna de Santa Rosa and Russian Rivers; the Wilson Grove Formation Highlands by the Americano, Stemple, and Salmon Creeks. The Volcanic Highlands are drained by tributaries of the Napa, Sonoma, and Petaluma Rivers (fig. 2A).

For the purpose of this study, the 7 ground-water basins were grouped into three study areas based primarily on geology. The relatively flat lying alluvial-filled basins were combined into the Valley and Plains study area, the Wilson Grove Formation Highlands was taken as a study area, and the Volcanic Highlands was identified as the third study area (fig. 2A). 


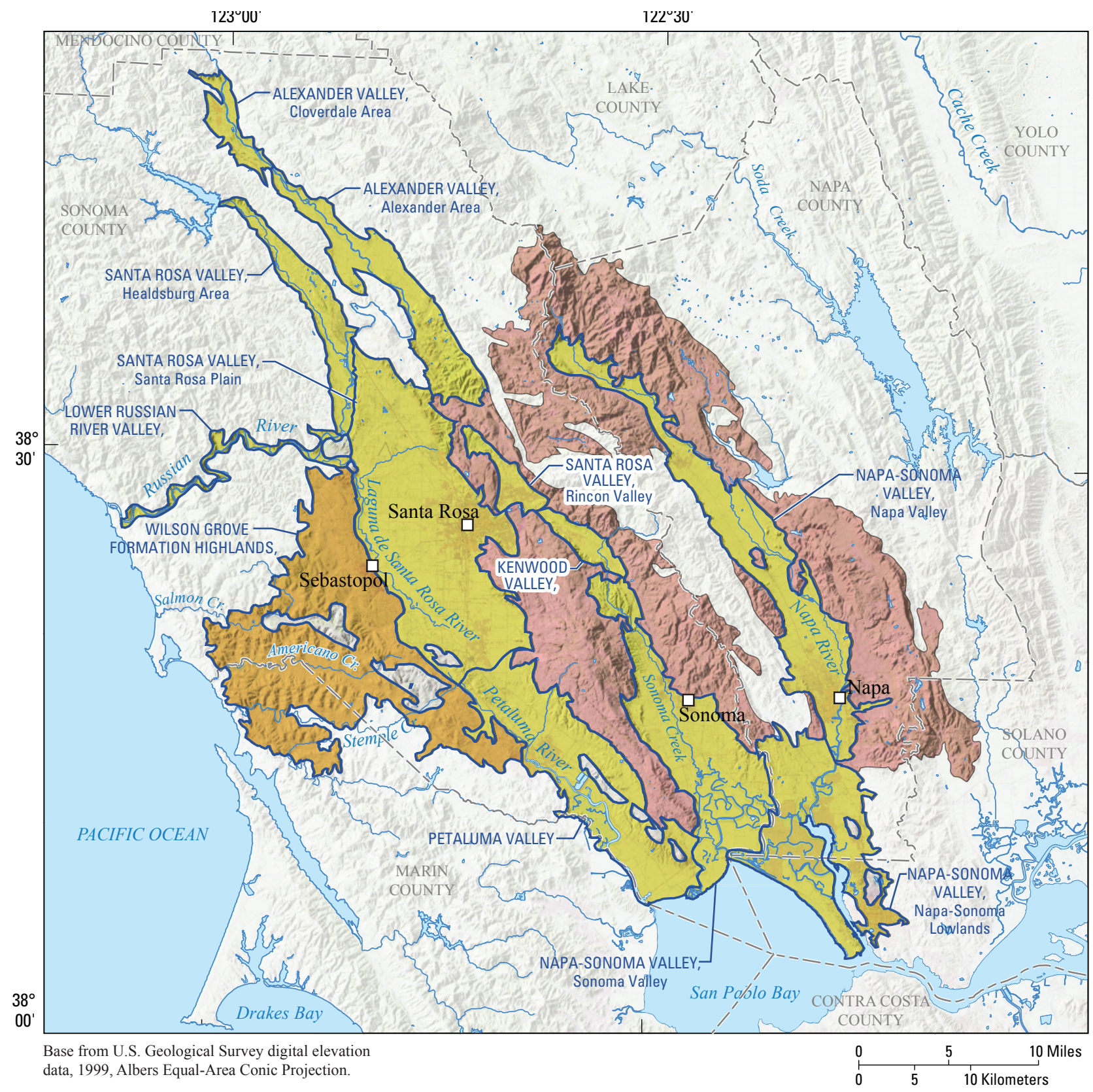

EXPLANATION

Study Areas
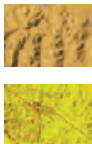

Valley and Plains

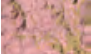

Volcanic Highlands
NAPA-SONOMA VALLEY, — Ground-water basin Sonoma Valley - Ground-water subbasin

Wilson Grove Formation Highlands<smiles>C1CCCCC1</smiles>

Ground-water basin boundary

Figure 2. $(A)$ the North San Francisco Bay GAMA study unit, locations of study areas, major cities, rivers, ground-water basins and subbasins and $(B)$ the North San Francisco Bay GAMA study unit, target wells, and 10-square-mile randomized sampling grid cells. 


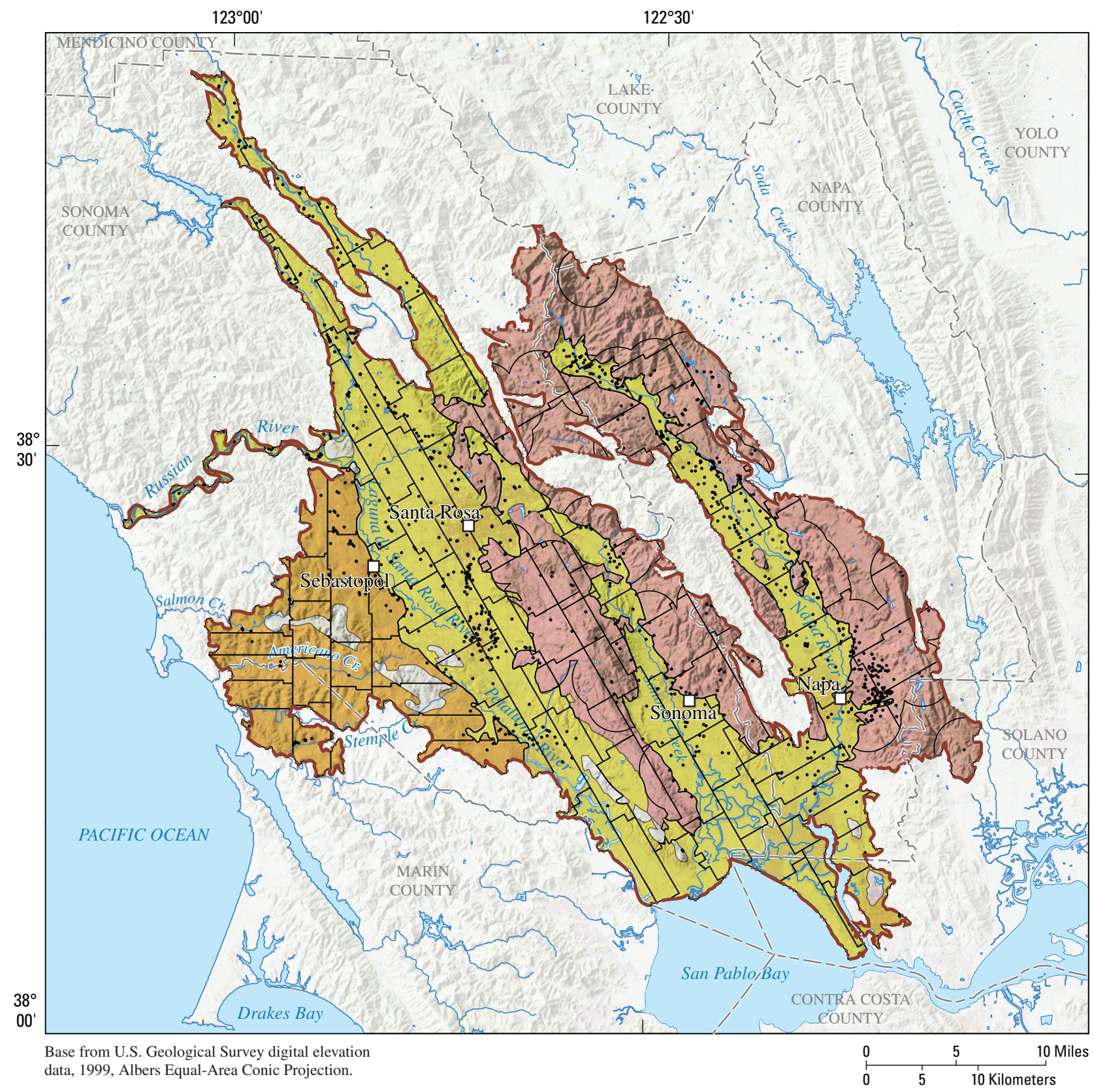

EXPLANATION

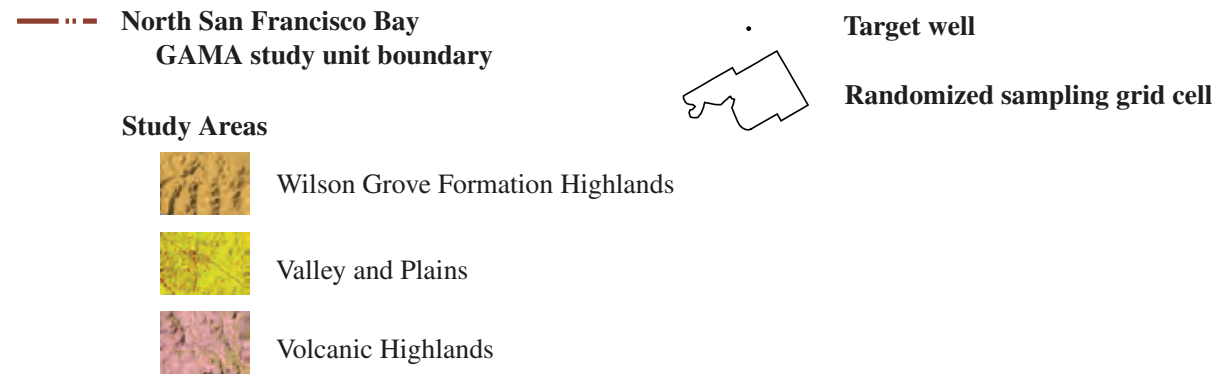

Figure 2.-Continued. 


\section{Valley and Plains Study Area}

The Valley and Plains study area (VP) extends from Alexander Valley in the north to the San Francisco Bay in the south, and includes most of the alluvial filled basins in the NSF Study Unit (fig. 3). These basins result from a series of northwest-trending structural depressions in the southern part of the Coast Ranges of northern California (Faye, 1973). Mountain ranges, from 1,000 to more than 4,000 ft in altitude, bound the VP study area to the north, northwest and east, and separate the Napa Valley, Sonoma Valley and the Santa Rosa Plain. The San Pablo Bay bounds the VP study area to the south, while the Wilson Grove Formation Highlands bounds the VP study area to the west.

The VP study area covers nearly $500 \mathrm{mi}^{2}$, and includes the Napa, Sonoma, Santa Rosa, Kenwood, Petaluma and Alexander Valleys, as well as the Napa-Sonoma lowlands to the south near San Pablo Bay (fig. 3). These valleys consist of a relatively thin cover of Quaternary alluvium overlying a thick section of Pliocene Volcanics, Cretaceous sedimentary rocks, Franciscan Formation metamorphics, and Jurassic serpentine and plutonic rocks (Faye, 1973).

In these valleys, the main water bearing unit is the alluvium that underlies and forms valley floors the thickness of which increases progressively from north to south and from the periphery of the valleys towards the rivers. In most valleys, the alluvium ranges in thickness from less than $10 \mathrm{ft}$ to more than $300 \mathrm{ft}$. Except for small localized areas of semiconfinement, water in the alluvium is unconfined and moves under a natural hydraulic gradient that conforms in a general way to the surface topography (Faye, 1973). Ground-water recharge to the alluvial aquifers occurs by stream-channel infiltration beneath the major rivers and their tributaries.

\section{Volcanic Highlands Study Area}

The Volcanic Highlands (VOL) study area (fig. 4) corresponds to hilly to mountainous areas of Pliocene volcanic deposits, which include lava flows, agglomerates, tuffs, and intercalated sediments of volcanic debris. These deposits, identified as the Sonoma Volcanics, have been subdivided in ascending order into the Mark West andesite, Sonoma tuff, and the St. Helena rhyolite (Osmont, 1905). These rocks have been folded, faulted, and eroded so that they now form a series of elongate ridges separating narrow alluvial valleys.
The VOL study area is approximately $390 \mathrm{mi}^{2}$ of discontinuous highlands that ring Napa Valley to the east, north, and northwest, and separate Santa Rosa Valley from Sonoma Valley, and Sonoma Valley from Napa Valley. For the purpose of this study, the VOL study area was defined as the area within about 2 mi of a public-supply well, completed in the volcanic formations.

Pumice tuff, tuff breccias, and redeposited stratified tuff form the most important water bearing units in the Sonoma Volcanics, and occur interspersed with the andesitic and basaltic flows that are largely impervious and act as confining beds, which restrict the movement of ground water (Cardwell, 1958). The thickness of the Sonoma Volcanics is not uniform. On the northeast side of Kenwood valley tuff and tuff breccias deposits are up to $1,200 \mathrm{ft}$ in thickness, overlying $800 \mathrm{ft}$ of basalt flows.

\section{Wilson Grove Formation Highlands Study Area}

The Wilson Grove Formation Highlands (WG) study area is a coastal area characterized by gently rolling hills, broad valleys, and rounded hilltops between Santa Rosa Valley and the Pacific Ocean (fig. 5). The WG study area corresponds to the Wilson Grove Formation Highlands ground-water basin (California Department of Water Resources, 2003) in Marin and Sonoma counties of California. The WG study area covers approximately $140 \mathrm{mi}^{2}$, and is bound to the north and south by rugged coastal mountains up to $1,000 \mathrm{ft}$ in altitude; to the west by the Pacific Ocean; and to the east by Santa Rosa Valley. The Wilson Grove Formation Highlands is named for the main geological unit underlying the area, the Wilson Grove Formation (Fox, 1983), and was previously described as the Merced Formation (Johnson, 1934). The marine deposits of the Wilson Grove Formation contain fine grained fossiliferous sandstones with lenses of conglomerate and sandy shale, and are underlain by Franciscan basement rock.

The Wilson Grove Formation represents the main waterbearing unit due to its extent, high porosity, and moderate transmissivity (Cardwell, 1958). The Wilson Grove Formation shallow-marine deposits, derived from the Franciscan group, range between 300 to $2000 \mathrm{ft}$ total thickness.

Mean annual precipitation in the study area, at Graton, California, is 42 in. with a mean annual temperature of $57^{\circ} \mathrm{F}$. The WG study area is drained by the Salmon, Americano, and Stemple Creeks (fig. 5). Sources of ground-water recharge include percolation of precipitation, and river and stream runoff. 


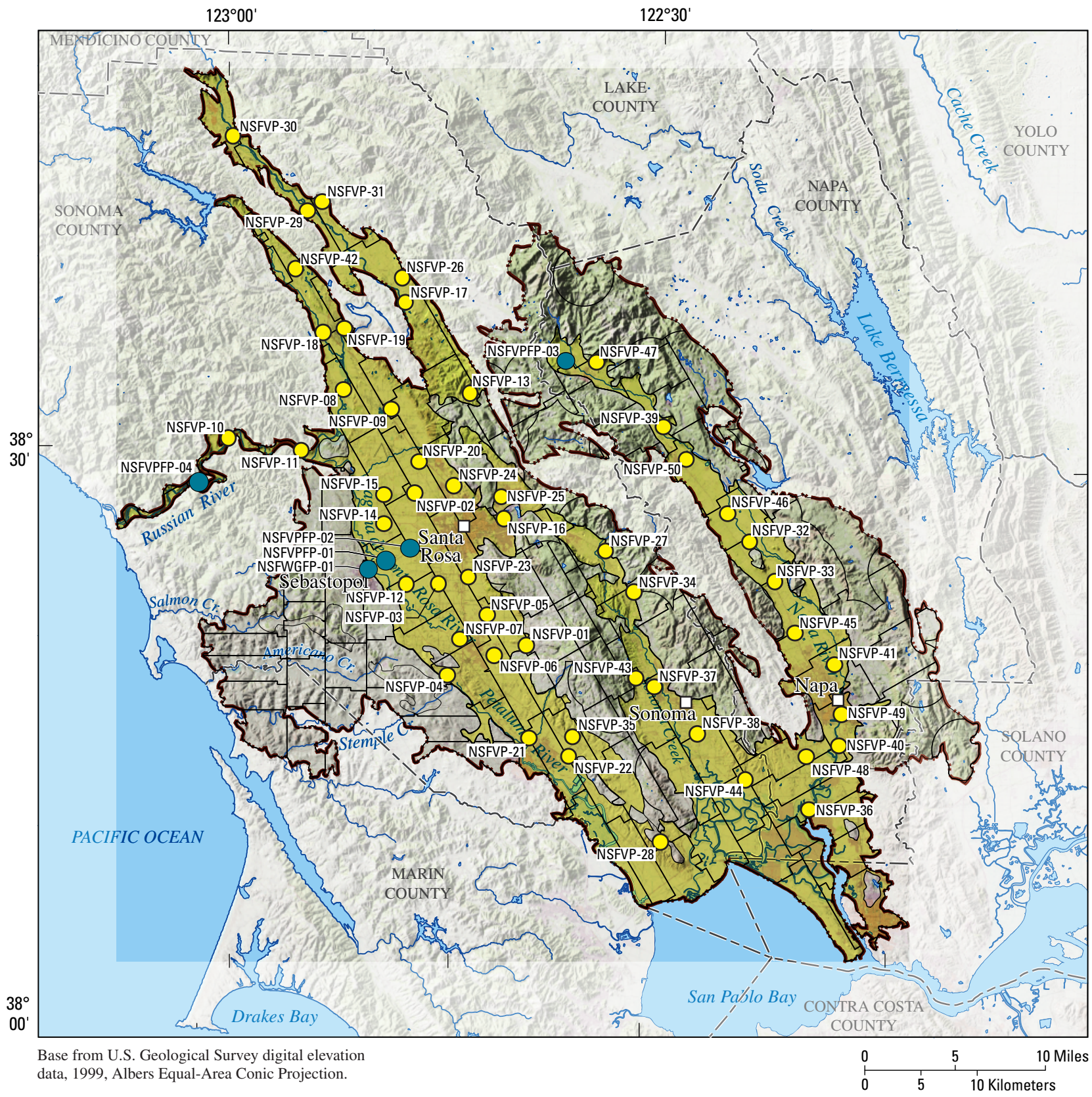

\section{EXPLANATION}

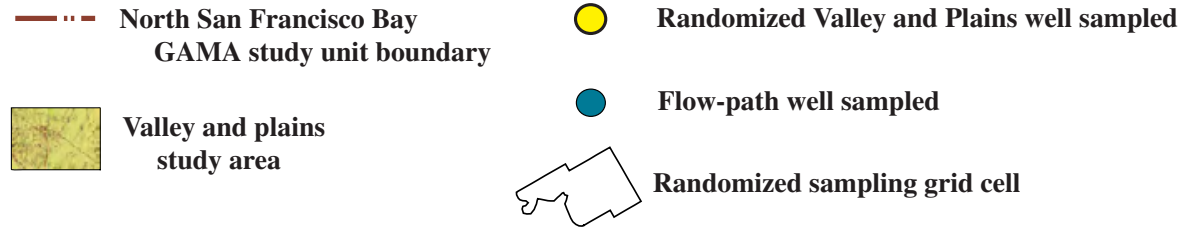

Figure 3. The Valley and Plains study area showing the locations of the randomized public-supply wells and flow-path wells sampled for the North San Francisco Bay GAMA study, California. 


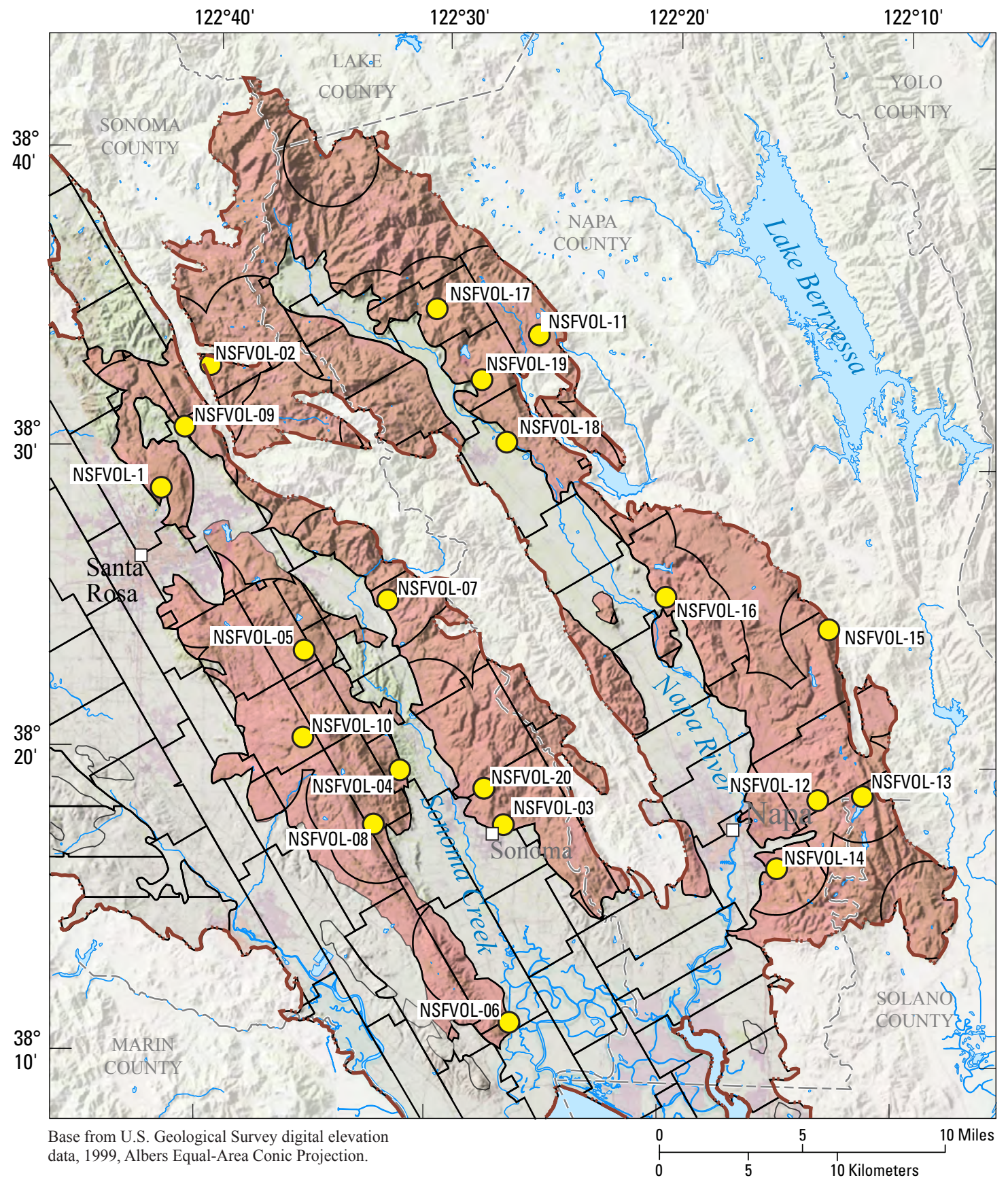

\section{EXPLANATION}

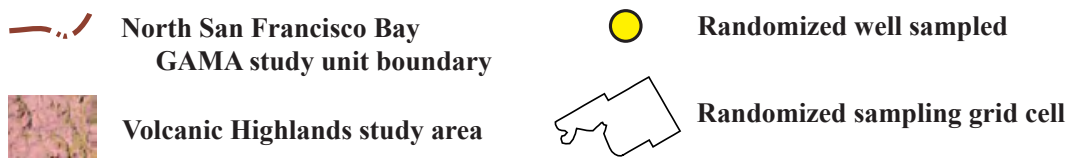

Figure 4. The Volcanic Highlands study area showing the randomized sampling grid cells and locations of the randomized public-supply wells sampled for the North San Francisco Bay GAMA study, California. 


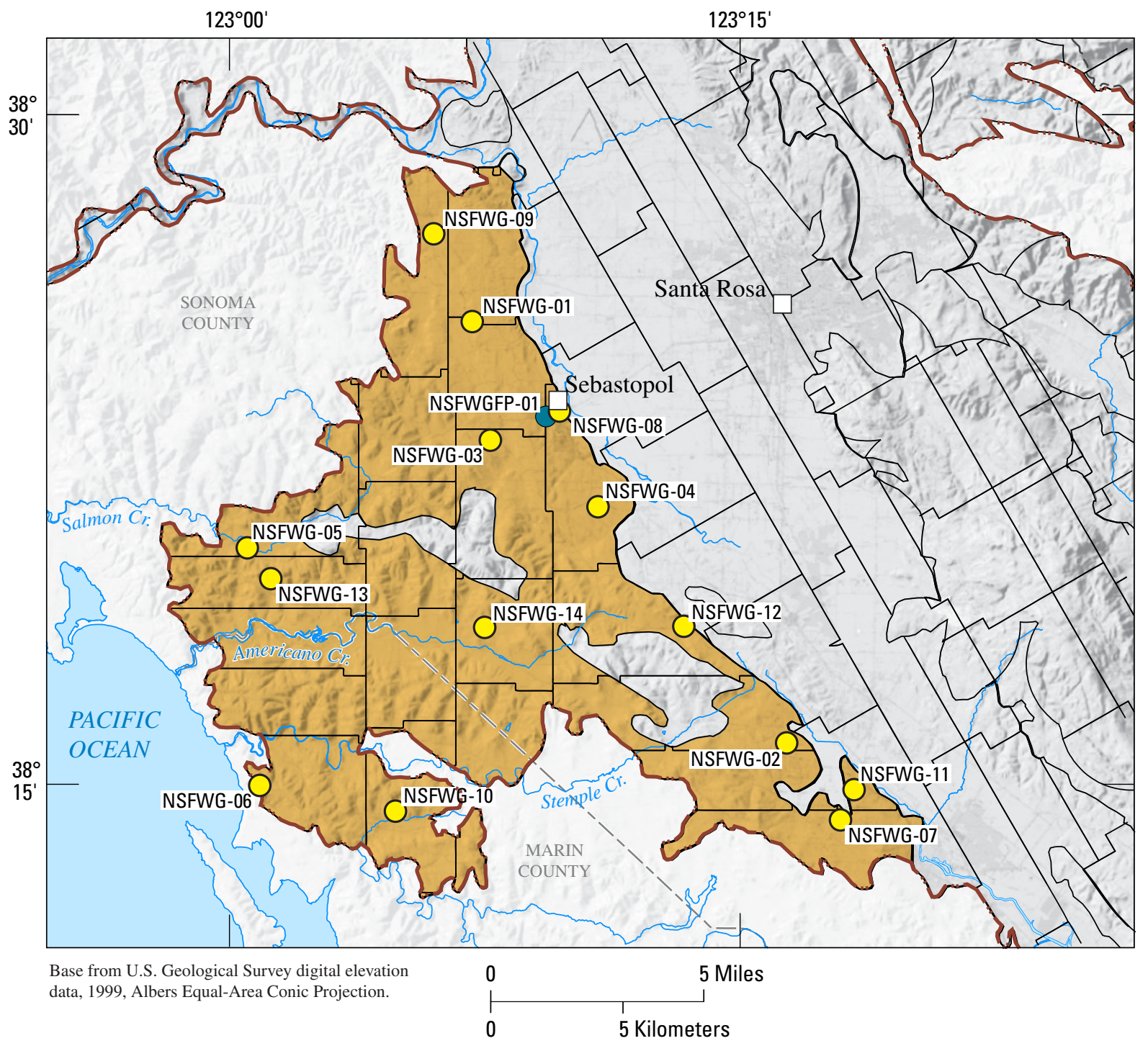

EXPLANATION

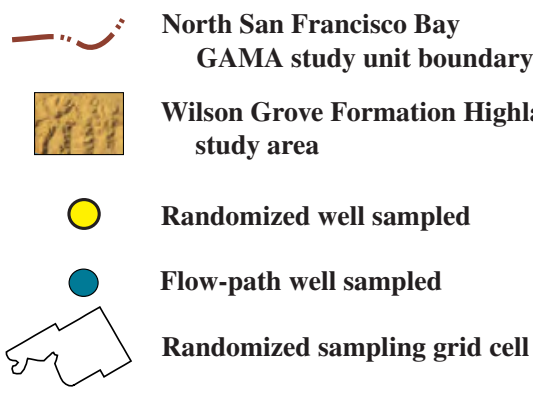

Figure 5. The Wilson Grove Formation Highlands study area, randomized sampling grid cells, and the locations of the randomized public-supply wells and flow path well sampled for the North San Francisco Bay GAMA study, California. 


\section{Hydrothermal Study}

The hydrothermal (HOT) study involved the characterization of 7 hydrothermal wells and 1 hydrothermal spring (fig. 6). Five hydrothermal wells were sampled in the northern Napa Valley near the city of Calistoga, 2 hydrothermal wells were sample in Sonoma Valley near Aqua Caliente, and 1 hydrothermal spring (NSFHOT-08) was sampled east of Saint Helena in hills composed of Cretaceous and Jurassic Franciscan complex rocks (Cardwell, 1958).

The wells and spring sampled for the hydrothermal study are used for mineral baths, not for drinking water supply. These wells are not included in the statistical treatment of the data as they are not public-supply drinking-water wells.

\section{Methods}

\section{Sampling Design}

The North San Francisco Bay study was designed to provide a spatially-unbiased assessment of ground-water quality within the study unit, as well as a statistically-consistent basis for comparing water quality in different study units. The results of this study will provide the data to assess the status, or current quality of the ground-water resource.

Ground-water basins identified by the Department of Water Resources (California Department of Water Resources, 2003) were used to define the study area boundaries (fig. 2), except in the case of the VOL study area (fig. 4). The boundary for the VOL study area was designated by the area within about $2 \mathrm{mi}$ of a public-supply well, completed in the volcanic formation. For a spatially unbiased and consistent assessment of ground-water quality (Scott, 1990), each of the study areas (not including the hydrothermal study) was subdivided into grid cells approximating $10 \mathrm{mi}^{2}$ (fig. $2 B$ ).

For this assessment, the VP study area was divided into 60 grid cells, the WG study area into 20 grid cells, and the VOL study area into 20 grid cells. If a grid cell contained more than one public-supply well, each well in that grid cell was randomly assigned a rank. In each grid cell with multiple wells, the highest ranked well was given priority for sampling. In this fashion, a public-supply well was selected in each cell to provide a spatially distributed, randomized monitoring network for each study area. Wells sampled as part of the gridcell network are hereafter referred to as randomized wells. An attempt was made to select one well per grid cell, however, some grid cells did not contain accessible wells. Wells from adjacent cells were selected to account for grid cells that had no active wells. Initial target wells (fig. $2 B$ ) were obtained from statewide databases maintained by the USGS and the California Department of Health Services.

Additional wells were sampled for focused studies specific to an area, including the source of high-salinity waters in the southern lowlands area, the contribution of hydrothermal water to the ground-water system in the Napa and Sonoma Valleys (hydrothermal study), and the source and movement of ground water in the Alexander, Napa, Sonoma, and Santa Rosa Valleys (flow paths) (figs. 3, 4, 6). Wells sampled as part of the focused studies were not included in the statistical characterization of water quality in the NSF study unit.

Randomized wells sampled as part of the NSF GAMA study unit were numbered with the following prefixes based on study area: The Valley and Plains study area (NSFVP), the Wilson Grove Formation Highlands study area (NSFWG), and the Volcanic Highlands study area (NSFVOL). Additional (non randomized) wells were sampled as part of the hydrothermal study (NSFHOT), and in the Valley and Plain and Wilson Grove study areas in order to ascertain ground-water quality along flow paths; these wells were given the designations NSFVPFP and NSFWGFP.

Table 1 provides the GAMA-id (alphanumeric identification number) for each well, along with the sampling schedule, time and data sampled and well-construction information. Ground-water samples were collected from 89 public-supply wells, 7 hydrothermal wells, and 1 hydrothermal spring from August to November 2004. Of the 89 public-supply wells sampled, 54 were in the Valley and Plains study area, 15 in the Wilson Grove Formation Highlands study area, and 20 in the Volcanic Highlands study area. Seven hydrothermal wells and 1 hydrothermal spring, which are used for recreational supply, were sampled for the hydrothermal study.

For this study, raw (untreated) ground-water samples were analyzed for 88 volatile organic compounds (VOCs), 122 pesticide and pesticide degradates, 63 waste-water indicators, 25 trace elements, 9 major and minor ions, 8 isotopic constituents, 5 noble gases, 5 nutrients, 3 constituents of special interest [N-nitrosodimethylamine (NDMA), trichlorpropane (TCP), and perchlorate], dissolved organic carbon (DOC), dissolved methane, oxygen, nitrogen and carbon dioxide, and the microbial constituents coliform and coliphage (tables $2 A-L$ ). General water-quality indicators that were determined in the field are dissolved oxygen (DO), $\mathrm{pH}$, specific conductance (SC), alkalinity, and temperature.

Results of analyses were tabulated as concentrations measured in the raw water samples. Concentrations of the constituents were compared to established maximum contaminant level (MCL), secondary maximum contaminant level (SMCL), California notification level (NL) and detection level for the purpose of reporting (DLR). 


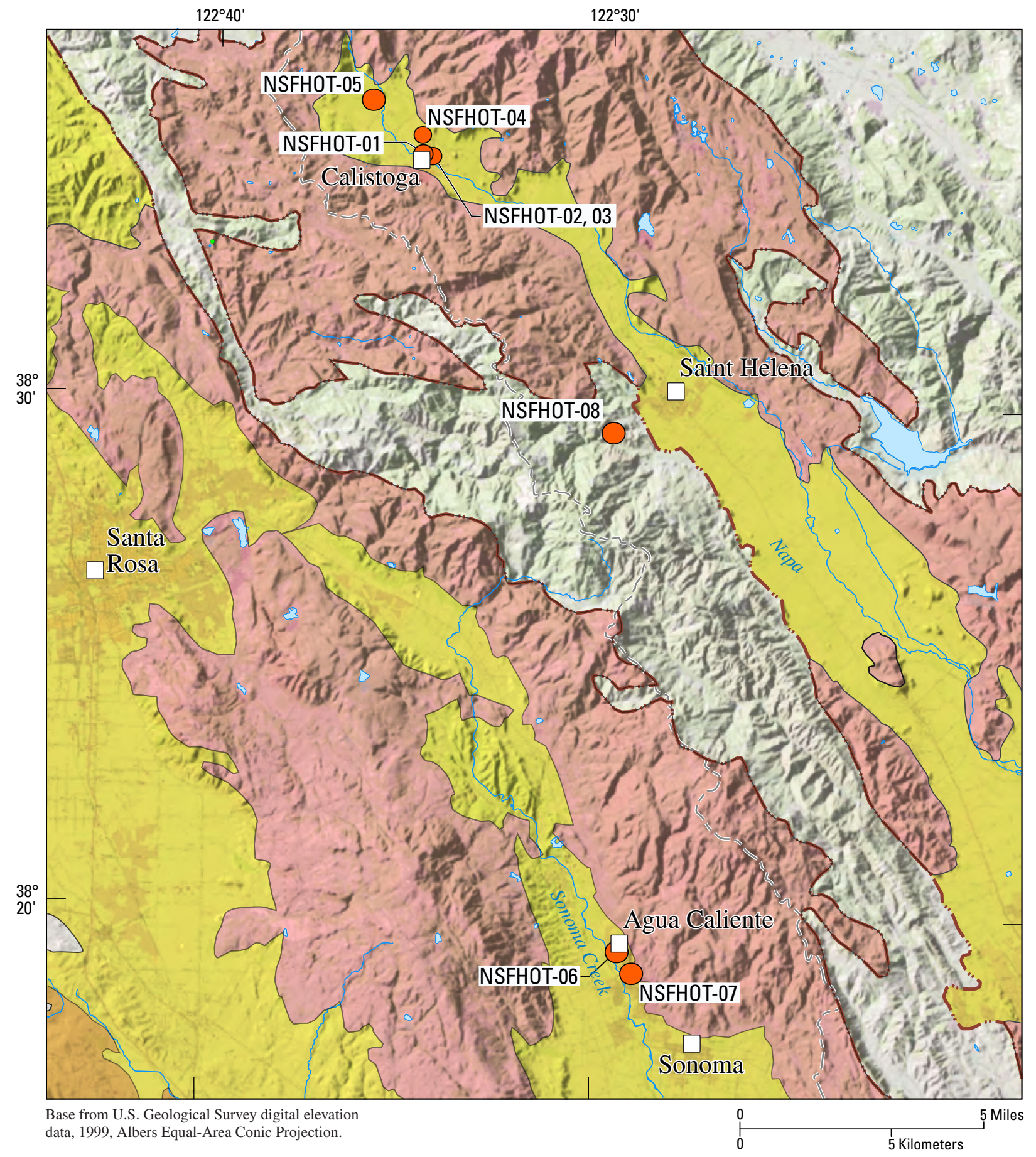

EXPLANATION

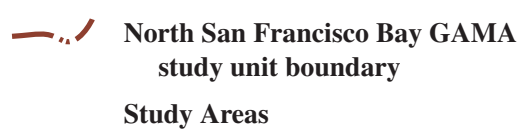

NSFHOT-05

Hydrothermal study well or spring sampled

Study Areas

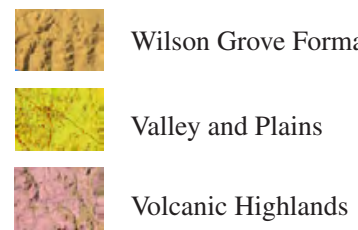

Figure 6. The hydrothermal study wells and spring sampled for the North San Francisco Bay GAMA study, California. 


\section{Sample Collection}

Eighty-nine public-supply wells were sampled in the Valley and Plains, Wilson Grove Formation Highlands, and Volcanic Highlands study areas, which comprise the NSF study unit. During the course of this study, target wells were sampled on either an expanded, basic, basic-plus, or hydrothermal schedule (table 3). The expanded schedule included analyses of 361 constituents and 19 additional water-quality indicators (tables $2 A-L$ ). The basic schedule included analyses for 302 constituents and 2 water-quality indicators, while the basic plus schedule added major and minor ions, trace elements, and dissolved gases to the basic schedule.

An attempt was made to sample wells that were located in areas of special interest, such as along flow paths (based on potentiometric surfaces), using the expanded schedule. In the NSF study unit, 25 percent of the ground-water wells were sampled on the expanded schedule, 12 percent were sampled on the basic-plus schedule, and 63 percent on the basic schedule. Wells along flow paths were sampled using the expanded or basic-plus schedules. Wells in the Napa Valley and the Napa-Sonoma Lowlands (fig. 3) were sampled using the basicplus schedule. Hydrothermal wells and springs were sampled using the hydrothermal schedule, which included dissolved gases, tritium, major and minor ions and chromium analyses.

Samples were collected using the USGS National Water Quality Assessment (NAWQA) program protocols (Koterba and others, 1995; U.S. Geological Survey, variously dated). These sampling protocols ensure that a representative sample of ground water was collected at each site and that the samples were collected and handled in a way that minimized the potential for airborne contamination of samples and (or) cross contamination between samples collected at wells. Additional details on sample collection may be found in the analytical methods references discussed in the Sample Analysis section.

Prior to sampling, each well was pumped continuously in order to purge at least three casing-volumes of water from the well. Samples were collected before filtration or chemical treatment, such as chlorination. If a chlorinating system was attached to the well, the chlorinator was shut off at least $24 \mathrm{hrs}$ prior to purging and sampling the well.

For ground-water sample collection, Teflon tubing was affixed to the hosebib or sampling port closest to the well head using stainless steel fittings. For the basic schedule, samples were collected at the well head using a 12-in. length of Teflon tubing.

For the expanded schedule, the samples were collected inside an enclosed chamber located inside a mobile laboratory and connected to the well head by a 10 to $50 \mathrm{ft}$ length of the Teflon tubing. Under the expanded schedule, ground water was pumped through a flow-through chamber fitted with a multi-probe meter that simultaneously measures the following water-quality indicators: $\mathrm{DO}$, temperature, $\mathrm{pH}$, turbidity, and specific conductivity (SC). Ground-water samples were collected when the temperature, $\mathrm{DO}$, and $\mathrm{pH}$ values being measured remained stable for 20 minutes.

Ground-water samples were filtered in the field using a $0.45-\mu \mathrm{m}$ capsule or disk filter. Polyethylene bottles were pre-rinsed using native water three times before sample collection. Some samples were preserved with acid, to a $\mathrm{pH}$ of 2 or less. Temperature sensitive samples were stored on ice prior to daily shipping to the various laboratories. The nontemperature sensitive samples for tritium, noble gases, stable isotopes, and carbon isotopes were shipped monthly, while radium isotopes, gross alpha/ beta, and radon-222 samples were shipped daily.

Volatile organic compounds (VOCs) and gasoline additives and (or) oxygenates (tables $2 A, 2 B$, at the back of this report) were collected in $40-\mathrm{mL}$ sample vials that were purged with three vial volumes of sample water before bottom filling to eliminate atmospheric contamination. Six normal (N) hydrochloric acid $(\mathrm{HCl})$ was added as a preservative to the VOC samples, but not to the gasoline additives and (or) oxygenate samples. Pesticides, pesticide degradation products (tables $2 C, 2 D$ ), waste-water indicators (table $2 E$ ), trichloropropane (1,2,3-TCP), and N-nitrosodimethylamine (NDMA) (table $2 F$ ) were collected in 1-L baked amber bottles; these samples were filtered at their respective laboratories prior to analysis. Perchlorate and nutrient samples each were filtered into 125 -mL polyethylene bottles (tables $2 F, 2 G$ ). DOC was collected at the well head after rinsing the sampling equipment using water from the sampling port that was filtered using a $50-\mathrm{mL}$ syringe and $0.45-\mu \mathrm{m}$ disk filter. The ground water sample then was filtered into a $125-\mathrm{mL}$ baked glass bottle and preserved with $4.5 \mathrm{~N}$ sulfuric acid (table $2 G$ ).

Ground-water samples for the analysis of major and minor ions, and trace elements were collected by filtering ground water into two $250-\mathrm{mL}$ polyethylene bottles, and then preserving one bottle with $7.5 \mathrm{~N}$ nitric acid (table $2 \mathrm{H}$ ). Arsenic and iron speciation samples were filtered into a $250-\mathrm{mL}$ polyethylene bottle that was covered with tape to prevent light exposure, and preserved with $6 \mathrm{~N} \mathrm{HCl}$ (table 2I).

Chromium, radon-222, tritium, and dissolved gases were collected from the hosebib at the well head, regardless of the sampling schedule (expanded, basic, or basic-plus). Chromium speciation samples were collected using a $10-\mathrm{mL}$ syringe with an attached $0.45-\mu \mathrm{m}$ disk filter. After the syringe was thoroughly rinsed and filled with ground water, $4 \mathrm{~mL}$ was forced through the disk filter, the next $2 \mathrm{~mL}$ of the ground water was slowly filtered into a small centrifuge vial for analysis of total chromium (table 2I). Hexavalent chromium, $\mathrm{Cr}(\mathrm{VI})$ was then collected by attaching a small cation exchange column to the syringe filter, and after conditioning the column with $2 \mathrm{~mL}$ of sample water, $2 \mathrm{~mL}$ was collected in a second centrifuge vial. Both vials were preserved with $10 \mu \mathrm{L}$ of $7.5 \mathrm{~N}$ nitric acid (Ball and McClesky, 2003). 
Tritium samples were collected at the well head by bottom filling two 1-L glass bottles with unfiltered ground water, after first rinsing the bottle with three volumes of water (table $2 J$ ). Stable isotopes of water were collected in $60-\mathrm{mL}$ clear glass bottles filled with unfiltered water, sealed with a conical cap, and secured with electrical tape to prevent leakage and evaporation (table 2J). Radium isotopes and gross alpha/ beta samples were collected and preserved in the same manner as major and minor ions, except 2 and 1-L aliquots of ground water were taken, respectively (table $2 \mathrm{~J}$ ). Mercury samples were collected by filtering ground water into a $250-\mathrm{mL}$ glass bottle and preserving with $6 \mathrm{~N} \mathrm{HCl}$. Carbon isotope samples were filtered and bottom filled into two $500-\mathrm{mL}$ baked glass containers that were first rinsed with three bottle volumes of ground water (table 2J). These samples had no headspace, and were sealed with a conical cap to avoid atmospheric contamination. Samples for alkalinity were collected by filtering ground water into a $500-\mathrm{mL}$ polyethylene bottle.

For the collection of radon-222, a stainless steel and Teflon valve assembly was attached to the sampling port at the well head. The valve was partially closed to create back pressure, and a $10-\mathrm{mL}$ sample was taken through a Teflon septum on the value assembly using a glass syringe affixed with a stainless steel needle. The sample was then injected into a $25-\mathrm{mL}$ vial partially filled with scintillation cocktail (mineral oil) and shaken. The vial was then placed in a cardboard tube in order to shield it from light during shipping (U.S. Geological Survey, variously dated).

Noble gases were collected in $3 / 8$ in. ID copper tubes using reinforced nylon tubing connected to the hosebib at the wellhead (table $2 K$ ). Ground water was flushed through the tubing to dislodge bubbles before flow was restricted with a back pressure valve. Clamps on either side of the copper tube were then tightened, trapping a sample of ground water for analyses of noble gases (Weiss, 1968). Dissolved gas $\left(\mathrm{CH}_{4}\right.$, $\mathrm{CO}_{2}, \mathrm{O}_{2}$, Ar, and $\mathrm{N}_{2}$ ) samples were collected in $40-\mathrm{mL}$, amber glass vials (USEPA VOA vials with screw-top septa). The vials were filled to the top with no headspace, and bubbles (atmospheric contamination) were carefully avoided. Samples were taken in triplicate.

Microbial constituents also were collected at the well head (table 2L). Prior to the collection of samples, the sampling port was sterilized using isopropyl alcohol, and ground water was run through the sampling port for at least three minutes to remove any traces of the sterilizing agent. Two sterilized $250-\mathrm{mL}$ bottles were then filled with ground water for coliform analyses (total and Escherichia coliform determinations), and one sterilized 3-liter carboy was filled for coliphage analyses (F specific and somatic coliphage determinations).

\section{Sample Analysis}

Nine laboratories performed chemical and microbial analyses for the NSF GAMA study. The following analytical methods were employed for the determination of organic and inorganic analytes by the USGS National Water-Quality Laboratory (NWQL): VOCs were measured by purge and trap capillary gas chromatography-mass spectrometry (Connor and others, 1998); gasoline additives and (or) oxygenates by heated purge and trap, gas chromatography-mass spectrometry (Rose and Sandstrom, 2003); pesticides by solid-phase extraction and chromatography-mass spectrometry (Furlong and others, 2001; Sandstrom, and others, 2001); waste-water indicators by polystyrene-divinylbenzene solid-phase extraction and capillary-column gas chromatography-mass spectrometry (Zaugg and others, 2002); major and minor ions, trace elements, and nutrients by inductively coupled plasma mass spectrometry (ICP-MS), graphite furnace atomic absorption (GFAA), atomic fluorescence (AF), and colorimitetry (Fishman and Friedman, 1989; Fishman, 1993; Garbarino, 1999; Garbarino and Damrau, 2001; and Patton and Kryskalla, 2003); DOC by UV-promoted persulfate oxidation and infrared spectrometry (Brenton and Arnett, 1993); radon-222 by liquid scintillation counting (American Society for Testing and Materials, 1998a,b); dissolved solids by weighing the sample residue on evaporation at $180^{\circ} \mathrm{C}$ (Fishman and Friedman, 1989).

The following methods were used for analyses of organic and inorganic constituents and microbial constituents by laboratories other than the NWQL: Perchlorate, NDMA, and 1,2,3-trichloropropane analysis by Montgomery Watson and Harza Laboratory using chromatography and mass spectrometry (U.S. Environmental Protection Agency, 1996; Hautman and others, 1999); stable isotopes of water by the USGS Reston Stable Isotope Laboratory using gaseous hydrogen and carbon dioxide-water equilibration (Coplen and others, 1991; Coplen, 1994); chromium, iron, and arsenic analysis by the USGS National Research Program (NRP) laboratory in Boulder, Colorado, using UV-VIS spectrophotometery and atomic absorption spectroscopy (To and others, 1998; Ball and McClesky, 2003; McCleskey and others, 2003); F-specific and somatic coliphage analysis by the USGS Ohio Microbiology Laboratory (U.S. Environmental Protection Agency, 2001); tritium analysis at the USGS NRP Laboratory, Menlo Park, California, using electrolytic enrichment-liquid scintillation method (Thatcher and others, 1977); tritium (helium-3 ingrowth method) and noble gases using accelerator mass spectrometry at LLNL (Clarke and others, 1976; Moran and others, 2002); dissolved gas ( $\mathrm{Ar}, \mathrm{CH}_{4}, \mathrm{CO}_{4}, \mathrm{~N}_{2}, \mathrm{O}_{2}$ ) analyses, also at LLNL, were carried out on a Membrane Inlet Mass Spectrometer (Kana and others, 1994); radium-226, radium-228, gross alpha and beta radioactivity analysis by Eberline Analytical Services using alpha activity counting method (U.S. Environmental Protection Agency, 1980); carbon isotopes analysis by the University of Arizona at the Accelerated Mass Spectrometry Laboratory (Donahue and others, 1990; Jull, and others, 2004); total and Escherichia coliform analyzed by USGS in the mobile lab by counting colonies (U.S. Environmental Protection Agency, 2002b). 
Ground-water samples for arsenic and iron were analyzed at two different laboratories; total concentrations were measured at the NWQL in Denver, Colorado, while speciation was measured at the USGS National Research Program (NRP) Lab in Boulder, Colorado. Cr also was analyzed in ground-water samples at the NRP laboratory. The NRP laboratory method determines chromium speciation, including analysis for hexavalent chromium, which is classified as an unregulated contaminant monitoring regulation (UCMR) compound.

Alkalinity and the concentrations of bicarbonate $\left(\mathrm{HCO}_{3}^{-}\right)$and carbonate $\left(\mathrm{CO}_{3}{ }^{2-}\right)$ were measured on filtered samples by gran titration method (U.S. Geological Survey, variously dated). Turbidity, $\mathrm{pH}, \mathrm{SC}$, and temperature were measured in the field with calibrated instruments. Total coliforms and Escherichia coliform (E. coli) were counted, following a 22-24 hour incubation time, under an ultraviolet light.

\section{Data Reporting}

\section{Laboratory Reporting Conventions}

The USGS NWQL uses the laboratory reporting level (LRL) as a threshold for reporting analytical results. The LRL is set to minimize the reporting of false negatives (not detecting a compound when it is actually present in a sample) to less than 1 percent (Childress and others, 1999). The LRL is set at two-times the long-term method detection level (LTMDL), which is the average (long term) MDL calculated from multiple analytical measurements $(>50)$. The method detection limit (MDL) is the minimum concentration of a substance that can be measured and reported with 99 percent confidence that the concentration is greater than zero (at MDL there is less than 1 percent chance of a false positive) (U.S. Environmental Protection Agency, 2002a).

Detections below the LRL are reported as estimated concentrations (designated with an "E" before the value in the tables and text). For information-rich methods (including the VOC method used in this study), detections below LT-MDL also are reported as E-values. E-values also result from detections outside the range of calibration standards, for detections that did not pass laboratory quality-control analyses, and for samples that were diluted prior to analysis.

Some compound concentrations in this study are reported using minimum reporting levels (MRLs) or method uncertainties. The MRL is the smallest measurable concentration of a constituents the may be reliably reported using a given analytical method (Timme, 1995). The method uncertainty generally indicates the precision of a particular analytical measurement; it gives a range of values wherein the true value will be found.

\section{Constituents on Multiple Analytical Schedules}

Twenty three constituents targeted in the NSF GAMA study are determined by more than one analytical schedule (table 4). Method preference is determined by the analyzing agency (http://wwwnwql.cr.usgs.gov/USGS/Preferred_ method_selection_procedure.html). Results from certain analytical schedules are preferred over others because the methodology is more accurate and precise, and generally yields a greater sensitivity for a given compound. If a compound appears on multiple analytical schedules, then only the detections determined by the preferred analytical schedule are reported here.

\section{Quality Control}

Quality-control (QC) samples collected in the NSF study include source-solution blanks, field blanks, equipment blanks, replicates, and matrix and surrogate spikes. QC samples were collected to evaluate bias and variability of the water chemistry data that may have resulted from sample collection, processing, storage, transportation, and laboratory analysis.

\section{Blanks}

Blank samples (blanks) were collected using water (Nitrogen-Purged Universal blank water) certified to contain less than the LRL of MRL of the analytes investigated in the study. Three types of blanks were collected: source-solution, equipment, and field blanks. Source-solution blanks were collected to verify that the blank water used for equipment and field blanks was free of analytes. Equipment blanks were collected at the beginning of the study to determine the residual presence of analytes in the sampling equipment, such as if the fittings and tubing used to collect samples introduced contamination. The equipment blanks were collected at the beginning of the study at the USGS California Water Science Center in Sacramento, California. Field blanks were collected at 10 percent of the wells sampled to determine if procedures used in the field and (or) laboratory introduced contamination, and are analogous to equipment blanks collected in the field. Equipment and field blanks were analyzed for VOCs, pesticides, waste-water indicators, low-level nutrients, dissolved organic carbon, major and minor ions, and trace elements.

Source-solution blanks were collected at the sampling site by pouring blank water directly into sample containers that were preserved, stored, shipped, and analyzed in the same manner as the ground-water samples. For equipment and field blanks, blank water was either pumped or poured through the sampling equipment (fittings and tubing) used to collect ground water, then processed and transported using the same protocols for the ground-water samples. 
If a constituent was detected in an equipment or field blank, the associated source-solution blank results were examined for similar constituent detections. If the field blank (or equipment blank) and the source-solution blank contained the constituent, then the source solution water was interpreted as the origin of the contamination in the blanks, and the field (or equipment) blank detections using the same blank water were disregarded. If a field blank detection could not be attributed to the source solution, then the ground-water samples collected prior to, and following the blank were evaluated. If the ground-water samples prior to or following the contaminated field blank had no detections, then carry-over contamination was ruled out. If an analyte was detected in a blank at a concentration greater than the concentration measured in a ground-water sample collected prior to or following the blank sample, then the ground-water value was censored (table 5). Censored values are indicated by a ' $\mathrm{V}$ ' proceeding the value in the tables (12A-C, and 14), and are not considered in the summary statistics. If a compound was detected in multiple equipment and (or) field blanks, and the detections could not be attributed to the source-solution water, then any groundwater sample that had a detection of the compound in question was evaluated for possible contamination.

\section{Replicates}

Sequential replicate samples assess variability that may result from the processing and analyses of inorganic and organic constituents. Relative standard deviation (RSD) of the measured values was used in determining the variability between replicate pairs for each compound (table 6A-E). The RSD is defined as 100 times the standard deviation divided by the mean concentration for each replicate pair of samples. If one value in a sample pair was reported as a non-detection and the other value was reported as an estimate below the LRL or MRL, the RSD was set to zero because the values are analytically identical. If one value in a sample pair was reported as a non-detection and the other value was greater than the LRL or MRL, then the non-detection value was set equal to onequarter of the LRL and the RSD was calculated (Childress and others, 1999). Estimated values were not used for these calculations. Values of RSD less than 20 percent are considered acceptable in this study (Fishman and Friedman, 1989). High RSD values for a compound may indicate analytical uncertainty at low concentrations, particularly for concentrations within an order of magnitude of LT-MDL or MDL.

\section{Matrix Spikes}

Addition of a spike or known concentration of a constituent to a replicate environmental sample enables the analyzing laboratory to determine the effect of the matrix, in this case ground water, on the analytical technique used to measure the constituent. The known compounds added in matrix spikes are the same as those being analyzed in the method. This enables an analysis of matrix interferences on a compound by compound basis. Matrix spikes in the NSF GAMA study were added at the laboratory performing the analysis. Compounds with low recoveries ( $<70$ percent) are of potential concern if environmental concentrations are close to the MCLs; a concentration below an MCL could be falsely indicated (table $7 \mathrm{~A}-\mathrm{C}$ ). Conversely, compounds with high recoveries ( $>130$ percent) are of potential concern if the environmental concentrations exceed MCLs: a high recovery could falsely indicate a concentration above the MCL. Recoveries between 70 to 130 percent for matrix spikes were considered acceptable in this study (Fishman and Friedman, 1989).

\section{Surrogates}

Surrogate compounds are added to environmental samples in the laboratory prior to analyses in order to evaluate the recovery of similar constituents. Surrogate compounds were added to all ground-water and quality-control samples that were analyzed for VOCs, gasoline additives and (or) oxygenates, pesticides, and waste-water indicators. Surrogates are not normally found in environmental samples and are used to identify potential problems associated with laboratory analyses. Potential problems include matrix interferences (such as high levels of dissolved organic carbon) that produce a positive bias, and (or) incomplete laboratory recovery (possibly due to improper maintenance and calibration of analytical equipment) that produces a negative bias. Surrogates are used to identify general problems that may arise during sample analysis that could affect the analysis results for all compounds, whereas matrix spikes are used to indicate problems with specific compound analysis. A 70 to 130 percent recovery of surrogates is generally considered acceptable. Values outside this range indicate possible problems with the processing and analysis of samples (table 8) (Fishman and Friedman, 1989). 


\section{Results}

\section{Quality-Control Samples}

\section{Detections in Blanks}

\section{Equipment Blank}

The equipment blank performed on August 31, 2004, contained the following VOC and waste-water indicators: ethylbenzene (E $0.06 \mu \mathrm{g} / \mathrm{L}), m$-xylene plus $p$-xylene $(0.29 \mu \mathrm{g} / \mathrm{L}), o$-xylene $(\mathrm{E} 0.09 \mu \mathrm{g} / \mathrm{L})$, toluene $(0.1 \mu \mathrm{g} / \mathrm{L})$, and phenol $(0.6 \mu \mathrm{g} / \mathrm{L})$. However, none of these constituents were observed in ground-water samples taken on the same day, prior to, or following the equipment blank detection, and therefore do not impact ground-water sample results. Also detected in the equipment blank taken on August 31, 2004, were calcium $(0.01 \mathrm{mg} / \mathrm{L})$, silica $(0.04 \mathrm{mg} / \mathrm{L})$, and arsenic $(0.1 \mu \mathrm{g} / \mathrm{L})$. However, the average concentrations of $\mathrm{Ca}, \mathrm{Si}$, and As observed in ground-water samples were $23 \mathrm{mg} / \mathrm{L}, 72$ $\mathrm{mg} / \mathrm{L}$, and $13 \mu \mathrm{g} / \mathrm{L}$, respectively (table 15 ). The constituents detected in the equipment blank represent less than 1 percent of observed values, hence do not impact ground-water sample results.

\section{Field Blanks}

In the NSF GAMA study unit, field blanks were collected at approximately 10 percent of the sites sampled. Table 5 presents a summary of compound detections in field blanks. The VOCs, and their maximum concentrations, detected in field blanks include acetone (E $2.9 \mu \mathrm{g} / \mathrm{L})$, carbon disulfide (E $0.07 \mu \mathrm{g} / \mathrm{L})$, ethylbenzene (E $0.06 \mu \mathrm{g} / \mathrm{L}), m$-xylene plus $p$-xylene $(0.29 \mu \mathrm{g} / \mathrm{L}), o$-xylene $(0.11 \mu \mathrm{g} / \mathrm{L})$, and toluene $(0.11 \mu \mathrm{g} / \mathrm{L})$. Ground-water samples collected prior to, and following these field blanks were free from these constituents, hence no ground-water samples were censored as a result of these blank detections.

The pesticide compound atrazine, with a maximum estimated concentration of $\mathrm{E} 0.005 \mu \mathrm{g} / \mathrm{L}$, also was detected in one field blank. Ground-water samples collected prior to, and following this blank were free from atrazine, hence none were censored.

The waste-water indicators and their maximum concentrations detected in field blanks were naphthalene (E 0.04 $\mu \mathrm{g} / \mathrm{L})$, phenol (E $1.1 \mu \mathrm{g} / \mathrm{L})$, and triclosan $(\mathrm{E} 0.08 \mu \mathrm{g} / \mathrm{L})$, respectively. For the constituents naphthalene and triclosan, ground-water samples collected prior to, and following these blanks were free from these constituents, hence no groundwater samples were censored.
Eight field blank samples contained phenol with a maximum concentration of $1.1 \mu \mathrm{g} / \mathrm{L}$, as did six source-solution blanks with a maximum concentration of $0.6 \mu \mathrm{g} / \mathrm{L}$, and the equipment blank with a value of $0.6 \mu \mathrm{g} / \mathrm{L}$. As a result of the high detection frequency for phenol in blank samples, and relatively high detection frequency for phenol in ground-water samples, minimum concentration detected E $0.23 \mu \mathrm{g} / \mathrm{L}$, phenol has been removed from consideration in this study, so that further attention can be given to the analytical methodology. As a result, 48 ground-water sample detections for phenol were censored (table 5). Phenol concentrations observed in this study, maximum of $2.4 \mu \mathrm{g} / \mathrm{L}$ are far below the health advisory limit of $2,000 \mu \mathrm{g} / \mathrm{L}$.

Two major ions and one minor ion were detected in field blanks, with maximum concentrations; $\mathrm{Ca}$ (E $0.02 \mathrm{mg} / \mathrm{L}), \mathrm{Si}$ $(0.06 \mathrm{mg} / \mathrm{L})$, and I $(0.001 \mathrm{mg} / \mathrm{L})$, respectively. None of the ground-water samples had detections of $\mathrm{Ca}$ or $\mathrm{Si}$ lower than these values, hence none were censored. No ground-water samples prior to or following the blanks had concentrations of iodine lower than E $0.001 \mathrm{mg} / \mathrm{L}$, hence no values were censored. Four trace elements were detected in field blanks, $\mathrm{Al}$ ( $\mathrm{E}$ $0.9 \mu \mathrm{g} / \mathrm{L}), \mathrm{Mn}(\mathrm{E} 0.1 \mu \mathrm{g} / \mathrm{L}), \mathrm{Ni}(\mathrm{E} 0.07 \mu \mathrm{g} / \mathrm{L})$, and $\mathrm{Zn}(\mathrm{E} 0.5$ $\mu \mathrm{g} / \mathrm{L})$. None of the ground-water samples had detections of $\mathrm{Al}$, $\mathrm{Ni}$, or $\mathrm{Zn}$ lower than these values, hence none were censored. Mn concentrations measured in ground-water samples ranged from 0.1 to $1,220 \mu \mathrm{g} / \mathrm{L}$, however no detections in groundwater samples prior to or following the blanks had Mn concentrations lower than E $0.1 \mu \mathrm{g} / \mathrm{L}$, hence no values were censored.

Dissolved organic carbon (DOC) was detected in 2 out of 3 blanks, and as a result, ground-water samples with concentrations lower than $0.4 \mathrm{mg} / \mathrm{L}$ following the second blank were censored. Four ground-water sample DOC detections: E 0.3 $\mathrm{mg} / \mathrm{L}, 0.4 \mathrm{mg} / \mathrm{L}, 0.4 \mathrm{mg} / \mathrm{L}$, and E $0.2 \mathrm{mg} / \mathrm{L}$, following the 0.5 $\mathrm{mg} / \mathrm{L}$ blank detection, were censored (table 5).

\section{Variability in Replicate Samples}

The majority of replicate sample pairs collected during the NSF GAMA study had relative standard deviations (RSDs) of less than 20 percent (table $6 A-E$ ). Twenty-three replicate sample pairs representing 8 chemical constituents, 4 replicate sample pairs of radionuclides, and 9 replicate sample pairs of gross radioactivity in water, had RSDs greater than 20 percent; see tables $6 A$ to $6 E$ for details. However, the replicate sample pairs with high RSDs had very low measured concentrations, and at these low concentrations, small deviations in measured values account for large RSDs. Since the variability in measurements occurred at low concentrations, well below MCLs, this variability was not of QC concern, and no detections were censored as a result of variability in replicate sample samples. 


\section{Matrix Spike Recoveries}

Tables $7 \mathrm{~A}$ to $7 \mathrm{C}$ present a summary of matrix spike recoveries for the NSF GAMA study. Addition of a spike or known concentration of a constituent to an environmental sample enables the analyzing laboratory to determine the effect of the matrix, in this case ground water, on the analytical technique used to measure the constituent. Nine environmental samples were spiked with VOCs to calculate matrix spike recoveries. Acceptable spike recovery values range between 70 and 130 percent (Friedman and Erdmann, 1982) (table 7A). Seventy-four of the 90 spike compounds had recoveries between the acceptable range of 70 and 130 percent. Fifteen spike compounds had at least one matrix spike recovery greater than 130 percent. Six of these 15 VOCs were detected in ground-water samples; 1,1,1-trichloroethane (TCA) was detected in 1 ground-water sample, acetone was detected in 1 ground-water sample, bromodichloromethane was detected in 1 ground-water sample, bromoform (tribromomethane) was detected in 1 ground-water sample, carbon disulfide was detected in 8 ground-water samples, and tetrachloromethane (carbon tetrachloride) was detected in 1 ground-water sample. All detections in ground-water samples were at concentrations well below MCLs, and therefore are not of QC concern. Nitrosodimethylamine (NDMA) was the only spike compound that had a recovery below 70 percent, however it was not detected in ground-water samples (table 13A). [NOTE - low recoveries may indicate that this compound was not detected in some samples if it was present at very low concentrations].

Five environmental samples were spiked with pesticide and (or) pesticide degradate compounds in order to calculate matrix spike recoveries. Acceptable spike recovery values range between 70 and 130 percent. Seventeen of the 64 spike compounds had recoveries between the acceptable range of 70 and 130 percent (table 7B). Twelve spike compounds had recoveries greater than 130 percent. Of these 12 compounds, only atrazine was detected in ground-water samples. All detections in ground-water samples were at concentrations well below its MCL of $3 \mu \mathrm{g} / \mathrm{L}$ and, therefore, are not of QC concern. Thirty-eight spike compounds had recoveries below 70 percent. Of these 38 spike compounds, 2 were detected in ground-water samples, deethyl atrazine (DEET) and trifluralin, at concentrations below $0.007 \mu \mathrm{g} / \mathrm{L}$. Hence, if the poor spike recovery, even as low as 1 percent, reflects ground-water sample constituent recovery, reported values would still be below MCLs and this would not affect water-quality reporting. A single sample also was spiked with 63 compounds. Acceptable spike recovery values range between 70 and 130 percent. Fifty-one of the 63 compounds had recoveries between the acceptable range of 70 and 130 percent (table $7 B$ ); 2 were above the 130 percent limit, and 10 were below the 70 percent limit. None of these 12 spike compounds with poor recoveries were detected in ground-water samples (table 11B). [NOTE - low recoveries may indicate that this compound was not detected in some samples if it was present at very low concentrations].

Four environmental samples were spiked with wastewater indicator compounds to calculate matrix spike recoveries. Acceptable spike recovery values range between 70 and 130 percent (Fishman and Friedman, 1989). Nine of the 63 spike compounds had recoveries between the acceptable range of 70 and 130 percent (table $7 C$ ). Six spike compounds had at least one matrix spike recovery greater than 130 percent; of these 6 , only phenol was detected in ground-water samples. Fifty-two spike compounds had at least one matrix spike recovery below 70 percent. Of the fifty-two compounds, bisphenol-A was detected in 3 ground-water samples, $d$-limonene was detected in 1 ground-water sample, ethoxyoctylphenol (OPEO1) was detected in 1 ground-water sample, indole was detected in 3 ground-water samples, menthol was detected in 1 ground-water sample, naphthalene was detected in 1 ground-water sample, $p$-cresol was detected in 2 ground-water samples, phenol was detected in 47 ground-water samples, tetrachloroethene was detected in 3 ground-water samples, tribromomethane was detected in 2 ground-water samples, and triclosan was detected in 3 ground-water samples (table 12A-C). All compounds were detected at concentrations below the LT-MDL. D-limonene does not have an MCL. Hence, if the poor spike recovery, even as low as 1 percent, reflects ground-water sample constituent recovery, reported values would still be below MCLs and this would not affect water-quality reporting. [NOTE-low recoveries may indicate that this compound was not detected in some samples if it was present at very low concentrations].

\section{Surrogate Compound Recoveries}

Surrogate compounds were added to environmental samples in the laboratory and analyzed to evaluate the recovery of similar constituents. All 89 ground-water samples, 18 replicate pairs and 13 blanks analyzed for VOCs on analytical schedule 2020 had recoveries of the surrogates 1,2-dichloroethane-d4, 1-bromo-4-fluorobenzene, and toluene-d8 that were between the acceptable limit of 70 and 130 percent (table 8). The 89 ground-water samples, 18 replicate pairs and 13 blanks analyzed for VOCs on analytical schedule 4024 had recoveries of the surrogates 1,2-dichloroethane-d4, 1-bromo4-fluorobenzene, toluene-d8, and isobutyl alcohol-d6 that were between the acceptable limit of 70 and 130 percent (Fishman and Friedman, 1989). 
All 87 ground-water samples, 19 replicate pairs and 11 blanks analyzed for pesticide and pesticide degradates on analytical schedule 2003 had recoveries of the surrogate alpha$\mathrm{HCH}-\mathrm{d} 6$ that were between the acceptable limit of 70 and 130 percent (table 8 ). However, only 50 of the 87 groundwater samples had recoveries of the surrogate diazinon-d10 that were between the acceptable limit of 70 and 130 percent; 37 of the 87 ground-water samples, 8 of the 19 replicate pairs and 6 of the 11 blanks had recoveries of the surrogate diazinon-d10 that were below the acceptable limit of 70 percent recovery. None of the diazinon-d10 surrogate recoveries were above the acceptable limit of 130 percent in the ground-water samples, replicate pairs, and blanks. Eight of the 16 groundwater samples with detections of pesticides or pesticide degradates had recoveries of the surrogate diazinon-d10 that were below the acceptable limit of 70 percent recovery, however, the concentrations of the pesticide and pesticide degradate compounds measured in these eight ground-water samples were $<0.2 \mu \mathrm{g} / \mathrm{L}$, well below MCLs. Hence, if the poor surrogate recovery, even as low as 1 percent, reflects ground-water sample constituent recovery, reported values would still be below MCLs and this would not affect water-quality reporting.

The 22 ground-water samples, 7 of the 8 replicate pairs, and 4 blanks analyzed for pesticide and pesticide degradates on schedule 2003 had recoveries of the herbicide surrogate 2,4,5-T (2,4,5-trichlorophenoxyacetic acid), that were between the acceptable limit of 70 and 130 percent (table 8); one replicate pair had a recovery of the surrogate $2,4,5-\mathrm{T}$ that was 66 percent. However, all ground-water samples with detections of pesticides or pesticide degradates had recoveries of the surrogate 2, 4, 5-T that were between the acceptable limit of 70 and 130 percent.

Twenty-one of the 22 ground-water samples, 8 replicate pairs, and 4 blanks analyzed for pesticide and pesticide degradates on schedule 2003 had recoveries of the surrogate Barban that were between the acceptable limit of 70 and 130 percent (table 8); one ground-water sample with a detection of pesticide or pesticide degradates had a recovery of the surrogate Barban that was 59 percent.

Thirteen of the 22 ground-water samples, 3 of the 8 replicate pairs and 1 of the 4 blanks analyzed for pesticide and pesticide degradates on schedule 2003 had recoveries of the surrogate caffeine-13C that were between the acceptable limit of 70 and 130 percent (table 8). Nine ground-water samples, 5 replicate pairs, and 3 blanks had recoveries of the surrogate caffeine-13C that were greater than 130 percent. Two groundwater samples with a detection of pesticide or pesticide degradates had recoveries of the surrogate caffeine-13C that were greater than 130 percent, however, no ground-water samples had measured pesticide and (or) pesticide degradates above MCL limits, and hence, amplified surrogate recovery did not affect water-quality reporting.

Two of the 89 ground-water samples, none of the 19 replicate pairs, and none of the 21 blanks analyzed for wastewater indicators on schedule 1433 had recoveries of the surrogate bisphenol A-d3 that were between the acceptable limit of
70 and 130 percent (table 8); 87 of the 89 ground-water samples, 19 replicate pairs and 21 blanks analyzed for waste-water indicators on schedule 1433 had recoveries of the surrogate bisphenol A-d3 that were less than the acceptable limit of 70 percent. None of the bisphenol A-d 3 surrogate recoveries were above the acceptable limit of 130 percent in the ground-water samples, replicate pairs, and blanks. Fifty of the 52 groundwater samples with detections of waste-water indicators had recoveries of the surrogate bisphenol A-d 3 that were below the acceptable limit of 70 percent surrogate recovery, however, the concentrations of the waste-water indicators measured in these 26 ground-water samples were $<1.4 \mu \mathrm{g} / \mathrm{L}$, much below MCLs. Hence, if the poor surrogate recovery, even as low as 1 percent, reflects ground-water sample constituent recovery, reported values would still be below MCLs and this would not affect water-quality reporting.

Seventy-six of the 89 ground-water samples, 15 of the 19 replicate pairs and 17 of the 21 blanks analyzed for wastewater indicators on analytical schedule $1433 \mathrm{had}$ recoveries of the surrogate caffeine-13C that were between the acceptable limit of 70 and 130 percent (table 8); 13 of the 89 groundwater samples, 4 of the 19 replicate pairs and 4 of the 21 blanks analyzed for waste-water indicators had recoveries of the surrogate caffeine-13C that were less than the acceptable limit of 70 percent. None of the caffeine-13C surrogate recoveries were above the acceptable limit of 130 percent in the ground-water samples, replicate pairs, and blanks. Three of the 52 ground-water samples with detections of waste-water indicators had recoveries of the surrogate caffeine-13C that were below the acceptable limit of 70 percent recovery, however, concentrations of waste-water indicator constituents measured in ground-water samples were $<3.0 \mu \mathrm{g} / \mathrm{L}$, well below MCLs. Hence, if the poor surrogate recovery, even as low as 1 percent, reflects ground-water sample constituent recovery, reported values would still be below MCLs and this would not affect water-quality reporting.

None of the 89 ground-water samples, 19 replicate pairs and 21 blanks analyzed for waste-water indicators on analytical schedule 1433 had recoveries of the surrogate decafluorobiphenyl that were between the acceptable limit of 70 and 130 percent (table 8); 89 ground-water samples, 19 replicate pairs and 21 blanks analyzed for waste-water indicators had recoveries of the surrogate decafluorobiphenyl that were less than the acceptable limit of 70 percent. None of the decafluorobiphenyl surrogate recoveries were above the acceptable limit of 130 percent in the ground-water samples, replicate pairs, and blanks. Twenty-four ground-water samples with detections of waste-water indicators had recoveries of the surrogate decafluorobiphenyl that were below the acceptable limit of 70 percent recovery, however concentrations of waste-water indicators measured in ground-water samples were $<3.0 \mu \mathrm{g} / \mathrm{L}$, well below MCLs. Hence, if the poor surrogate recovery, even as low as 1 percent, reflects ground-water sample constituent recovery, reported values would still be below MCLs and this would not affect water-quality reporting. 
Eighty-five of the 89 ground-water samples, 17 of the 19 replicate pairs and 21 blanks analyzed for waste-water indicators on analytical schedule 1433 had recoveries of the surrogate fluoranthene-d10 that were within the acceptable range of 70 and 130 percent (table 8); 4 of the 89 groundwater samples, 2 of the 19 replicate pairs and none of the 21 blanks analyzed for waste-water indicators had recoveries of the surrogate fluoranthene-d10 that were less than the acceptable limit of 70 percent (table 8). None of the fluoranthened10 surrogate recoveries were above the acceptable limit of 130 percent in the ground-water samples, replicate pairs, and blanks. Two of the 52 ground-water samples with detections of waste-water indicators had recoveries of the surrogate fluoranthene-d 10 that were below the acceptable limit of 70 percent recovery; however, concentrations of waste-water indicators measured in ground-water samples were $<3.0 \mu \mathrm{g} / \mathrm{L}$, well below MCLs. Hence, if the poor surrogate recovery, even as low as 1 percent, reflects ground-water sample constituent recovery, reported values would still be below MCLs and this would not affect water-quality reporting.

All 87 ground-water samples, 12 replicate pairs and 4 blanks analyzed for constituents of special interest had recoveries of the surrogate toluene-d 8 that were between the acceptable limit of 70 and 130 percent (table 8). Fifty-two of the 87 ground-water samples, 5 of the 12 replicate pairs and 1 of the 4 blanks analyzed for constituents of special interest had recoveries of the surrogate fluoranthene-d10 that were between the acceptable limit of 70 and 130 percent; 52 of the 87 ground-water samples, 7 of the 12 replicate pairs and 3 of the 4 blanks analyzed for constituents of special interest all had recoveries of the surrogate NDMA-d6 that were less than the acceptable limit of 70 percent. One of the 87 groundwater samples, 2 of the 12 replicate pairs and 1 of the 4 blanks analyzed for constituents of special interest had recoveries of the surrogate NDMA-d6 that were greater than the acceptable limit of 130 percent. No constituents of special interest (table $2 F$ ) were detected in NSF study unit ground-water samples.

\section{Ground-Water Quality}

Results from raw (untreated) ground-water analyses for the NSF GAMA study are presented in tables 9 to 22 , at the end of this report. Table 9 includes water-quality indicators measured in the field, while tables 10-22 present the results of ground-water analyses organized by the compound types and classes: VOCs and gasoline additives and (or) oxygenates, pesticides and pesticide degradates, waste-water indicators, constituents of special interest, nutrients, major and minor ions, trace elements, arsenic and iron, chromium, isotopes and radioactivity, and microbial constituents. The summary tables present only the constituents that were detected, and only wells that had at least one compound detected. The tables are organized by study area, in which, rows list the GAMA iden- tification number for each well. The columns list the constituents detected, the associated USGS parameter code used to identify the compound and store the information in a computerized database (NWIS), and method of measurement and the laboratory reporting level (LRL) for which the compound may be detected.

The tables include the measured concentration of each constituent, the number of wells at which it was detected, the frequency at which it was detected (in relation to the total number of randomized wells sampled in the study area), the total number of constituents detected at each well, the total number of detections in each study area, and the detection frequency by compound class. Results from the flow-path wells and hydrothermal wells are listed in the tables, but these results are not included in statistical compilations because these wells were not part of the randomized well selection.

Detections that have concentrations or activities above the maximum contaminant level (MCL) are indicated in the tables by bold font; detections that have concentrations or activities above the secondary maximum contaminant level (SMCL) are indicated in the tables by italicized and bold font; detections that have concentrations or activities above the notification level or the detection level for the purpose of reporting (DLR) are indicated in the tables by italicized font.

\section{VOCs and Gasoline Additives and (or) Oxygenates}

Analytical results of VOCs and gasoline additives and (or) oxygenates from schedules 2020 and 4024 were combined in tables $10 \mathrm{~A}-\mathrm{C}$, which report results from the preferred analytical method. Ground-water samples for VOCs and gasoline additives and (or) oxygenates were collected at 89 public-supply wells sampled in the NSF GAMA study unit. Twenty-one VOCs and gasoline additives and (or) oxygenates were detected in 29 wells in the NSF study unit. Thirty-three percent of the 89 wells sampled had at least one detection of a VOC and gasoline additive and (or) oxygenate. Five of the 89 wells were flowpath wells and are not included in the following statistical calculations.

Seventeen of the 88 VOCs analyzed were detected in ground-water samples from randomized wells in the NSF study unit. Trichloromethane (chloroform), a disinfectant by product, was the most frequently detected VOC; it was detected in 12 of the 84 randomized wells sampled. The next most frequently detected VOC was carbon disulfide, a compound used in organic synthesis which also occurs naturally. It was detected in 8 of the 84 randomized wells. The third most frequently detected VOC, toluene, a gasoline additive, was detected in 4 of the 84 randomized wells sampled. In total, 27 wells (of the 84 total randomized wells) had 44 detections for a VOC detection frequency of 32 percent in the NSF study unit. None of the VOCs and gasoline additive and (or) oxygenate concentrations measured were greater than the concentrations established for regulatory purposes. 
In the VP study area, eleven of the 88 VOCs and gasoline additives and (or) oxygenates investigated were detected in 17 ground-water samples from 50 randomized wells (table $10 A)$. Trihalomethanes were the most frequently detected class of constituents in the VP study area; found in 9 of the 50 ground-water samples. Chloroform was the most frequently detected VOC; it was detected in 8 of the 50 randomized VP wells sampled. The next most frequently detected class of constituents was organic synthesis constituents, found in 8 of the wells. Carbon disulfide, a compound used in organic synthesis which also occurs naturally, was detected in 6 of the 50 randomized VP wells. The third most frequently detected class of constituents, gasoline additives and (or) oxygenates, were found in 4 of the 50 wells sampled.

In the VOL study area, eight of the 88 VOCs and gasoline additives and (or) oxygenates investigated were detected in 6 of the 20 ground-water samples from randomized wells (table 10B). Organic synthesis constituents were the most frequently detected class of constituents in the VOL study area; found in 3 of the 20 wells. Carbon disulfide was detected in 2 of the 20 randomized VOL wells sampled. The next most frequently detected class of constituents, gasoline additives and (or) oxygenates, were found in 2 of the $20 \mathrm{VOL}$ wells; toluene and $m$-xylene plus $p$-xylene were each detected in 2 of the 20 randomized VOL wells sampled. The third most frequently detected class of constituents, trihalomethanes, were also found in 2 of the 20 VOL randomized wells sampled; chloroform was found in 2 of the $20 \mathrm{VOL}$ samples.

In the WG study area, seven of the 88 VOCs or gasoline additives and (or) oxygenates investigated were detected in 4 of the 14 ground-water samples from randomized wells (table 10C). Trihalomethanes and solvents were the most frequently detected classes of constituents in the WG study area, each found in 2 of the 14 ground-water samples; chloroform was detected in 2 of the 14 randomized WG wells sampled. The next most frequently detected class of constituents, gasoline additives and (or) oxygenates, were found in 1 of the 14 WG wells. Ground-water samples for VOCs and gasoline additives and (or) oxygenates were not collected for the hydrothermal study.

\section{Pesticides and Pesticide Degradates}

Ground-water samples for pesticides and pesticide degradates, using analytical schedules 2003 and 2060, were collected at 89 wells in the NSF GAMA study unit. Nine pesticides and pesticide degradates were detected in 16 wells in the total NSF study unit. Sixteen of the 89 wells sampled had at least a single detection of a pesticide or pesticide degradate. Five of these 89 wells were flowpath wells and are not included in the following statistical calculations.

Nine of the 122 pesticides and pesticide degradates investigated were detected in ground-water samples from randomized wells in the NSF study unit. Simazine, an herbicide, was the most frequently detected. It was detected in 8 of the 84 ground-water samples from randomized wells. The pesticide degradates deethylatrazine and deisopropyl atrazine both were detected in 2 of the 84 randomized wells sampled. In total, 18 detections in 14 randomized wells, of the 84 were observed in the NSF study unit. None of the pesticide concentrations measured were greater than concentrations established for regulatory purposes.

In the VP study area, 4 herbicides and 3 pesticide degradates were detected in 12 of the 50 ground-water samples from randomized wells (table 11A). Herbicides were the most frequently detected among the pesticides and (or) pesticide degradates in the VP study area, found in 11 of the 50 groundwater samples. Simazine was the most frequently detected herbicide; it was detected in 8 of the 50 randomized VP wells sampled. The next most frequently detected class of constituents was pesticides and (or) pesticide degradates, found in 4 of the 50 wells; deethylatrazine and deisopropyl atrazine were each detected in 2 of the 50 randomized VP wells sampled.

In the VOL study area, one herbicide was detected in one of the 20 ground-water samples from randomized wells (table 11B). Diphenamid, an herbicide, was found in one of the ground-water samples. In the WG study area, one herbicide, diazinon, was detected in one of the 14 ground-water samples from randomized wells (table 11C). Ground-water samples for pesticides and pesticide degradates were not collected for the hydrothermal study.

\section{Waste-Water Indicators}

Ground-water samples for waste-water indicators, determined by analytical schedule 1433, were collected at 89 wells in the NSF GAMA study unit. Although compounds analyzed by schedule 1433 are referred to as waste-water indicators, these compounds may originate from sources other than waste water. Thirteen waste-water indicators were detected in 24 of the wells in the NSF study unit. Twenty-four of the 89 wells sampled had at least a single detection of a waste-water indicator. Forty-seven phenol detections were censored (concentration preceded by a $\mathrm{V}$ in tables $12 \mathrm{~A}-\mathrm{C}$ ) as a result of contamination of the equipment and field blanks, reflecting problems with the analytical procedures, see Quality-control section. These results were censored from summary statistical calculations. Five of the 89 wells were flowpath wells, and also were not included in the following statistical calculations.

Thirteen of the 63 waste-water indicators analyzed were detected in at least one ground-water sample from the randomized wells. Isophorone, a solvent, was the most frequently detected constituent; it was detected in 6 of the 84 randomized wells sampled. Caffeine and bisphenol-A were both detected in 3 of the 84 randomized wells sampled. In total, 30 detections in 22 randomized wells of the 84 were observed in the NSF study unit. None of the waste-water indicators detected in this study have regulatory standards. 
In the VP study area, 5 of the 63 waste-water indicators investigated were detected in 12 of the 50 ground-water samples from randomized wells (table 12A). Caffeine was the most frequently detected compound in the VP study area; it was detected in 4 of the 50 randomized VP wells sampled. Isophorone, a solvent, was detected in 3 of the 50 randomized wells. Triclosan, tetrachlorethene, and bromoform (tribromoethane) were all detected in 2 of the 50 randomized VP wells sampled.

In the VOL study area, eight waste-water indicators were detected in 6 of the 20 ground-water samples from the randomized wells (table 12B). Bisphenol-A, a flame retardant, and isophorone both were found in 2 of the 20 randomized VOL wells.

In the WG study area, five waste-water indicators were detected in 4 of the 14 ground-water samples from randomized wells (table 12C). Indole, a pesticide ingredient, and p-cresol, a wood preservative, were found in 2 of the 14 WG groundwater samples. Ground-water samples for waste-water indicators were not collected for the hydrothermal study.

\section{Constituents of Special Interest}

Ground-water samples for the constituents of special interest: perchlorate, 1,2,3-trichloropropane (TCP) and $\mathrm{N}$-nitrosodimethylamine (NDMA), were collected at 89 wells (table 13), however, these constituents were not detected in any of the wells sampled.

\section{Nutrients and Dissolved Organic Carbon}

Nutrients and dissolved organic carbon (DOC) samples were collected at 22 wells (table 14) sampled under the expanded schedule in the NSF study unit. Ammonia was detected in 9 of the 22 wells, at concentrations ranging from an estimated value (E) of 0.03 to $3.11 \mathrm{mg} / \mathrm{L}$. Nitrate plus nitrite was detected in 16 of the 22 ground-water samples, whereas nitrite was detected in only 6 of the 22 samples. Concentrations of nitrate plus nitrite were less than the MCL of $10 \mathrm{mg} / \mathrm{L}$ for nitrate alone; values ranged from an estimated value of $0.03 \mathrm{mg} / \mathrm{L}$ to a concentration of $3.22 \mathrm{mg} / \mathrm{L}$. Nitrite was detected in 6 wells at concentrations that ranged from an estimated value of $0.004 \mathrm{mg} / \mathrm{L}$ to a concentration of 0.03 $\mathrm{mg} / \mathrm{L}$; much below the nitrite MCL of $1 \mathrm{mg} / \mathrm{L}$. Dissolved phosphorus was measured in all 22 wells at concentrations that ranged from 0.008 to $0.559 \mathrm{mg} / \mathrm{L}$. Total nitrogen, dissolved (nitrate plus nitrite plus ammonia plus organic-N) was measured in all 22 wells at concentrations that ranged from 0.04 to $3.42 \mathrm{mg} / \mathrm{L}$. DOC was measured in all 22 wells at concentrations that ranged from E $0.2 \mathrm{mg} / \mathrm{L}$ to $1.2 \mathrm{mg} / \mathrm{L}$. Four samples had DOC detections in the preceding blanks greater than the sample values, and hence were censored and these data were not used for summary statistical calculations. Censored values are preceded by a $\mathrm{V}$ in table 14 .

\section{Major and Minor lons and Dissolved Solids}

Major and minor ions and dissolved solids (DS) samples were collected at 33 public-supply wells, 7 hydrothermal wells, and 1 hydrothermal spring (table 15). Three of the public-supply wells sampled in NSF study unit had DS concentrations above the recommended SMCL of $500 \mathrm{mg} / \mathrm{L}$, with values of 503,685 , and $1,000 \mathrm{mg} / \mathrm{L}$ respectively, and a mean value of $320 \mathrm{mg} / \mathrm{L}$. Calcium concentrations in publicsupply wells ranged from 0.9 to $53.6 \mathrm{mg} / \mathrm{L}$, with a mean value of $25.6 \mathrm{mg} / \mathrm{L}$. Magnesium concentrations in public-supply wells ranged from 0.1 to $50.8 \mathrm{mg} / \mathrm{L}$, with a mean value of $15.4 \mathrm{mg} / \mathrm{L}$. Potassium concentrations in public-supply wells ranged from 0.5 to $19.7 \mathrm{mg} / \mathrm{L}$, with a mean value of $4.0 \mathrm{mg} / \mathrm{L}$. Sodium concentrations in public-supply wells ranged from 8.4 to $270 \mathrm{mg} / \mathrm{L}$, with a mean value of $53.5 \mathrm{mg} / \mathrm{L}$. Bromide concentrations in public-supply wells ranged from $0.03 \mathrm{mg} / \mathrm{L}$ to $1.4 \mathrm{mg} / \mathrm{L}$, with a mean value of $0.2 \mathrm{mg} / \mathrm{L}$. Chloride concentrations in public-supply wells ranged from 4.6 to $249 \mathrm{mg} / \mathrm{L}$; just below the SMCL of $250 \mathrm{mg} / \mathrm{L}$, with a mean value of 32.8 $\mathrm{mg} / \mathrm{L}$. Fluoride concentrations in public-supply wells ranged from 0.1 to $0.7 \mathrm{mg} / \mathrm{L}$, with a mean value of $0.3 \mathrm{mg} / \mathrm{L}$; well below the MCL of $2 \mathrm{mg} / \mathrm{L}$. Iodide concentrations in publicsupply wells ranged from an estimated value of (E) 0.001 $\mathrm{mg} / \mathrm{L}$ to $1.1 \mathrm{mg} / \mathrm{L}$, with a mean value of $0.07 \mathrm{mg} / \mathrm{L}$. Silica concentrations in public-supply wells ranged from 15.9 to 134 $\mathrm{mg} / \mathrm{L}$, with a mean value of $61.4 \mathrm{mg} / \mathrm{L}$. Sulfate concentrations in public-supply wells ranged from 1.4 to $239 \mathrm{mg} / \mathrm{L}$; below the SMCL of $250 \mathrm{mg} / \mathrm{L}$. 


\section{Trace Elements}

Ground-water samples for trace elements were collected at 32 public-supply wells, 7 hydrothermal wells, and 1 hydrothermal spring (table 16) in the NSF study unit. Aluminum was detected in 18 ground-water samples with concentrations ranging from an estimated value of 1 to a value of $7 \mu \mathrm{g} / \mathrm{L}$. Antimony was detected in 4 ground-water samples with concentrations ranging from an estimated value of $(\mathrm{E})$ 0.11 to a value of $0.28 \mu \mathrm{g} / \mathrm{L}$. Arsenic was detected in 29 ground-water samples with concentrations ranging from an estimated value of (E) 0.1 to a concentration of $32.8 \mu \mathrm{g} / \mathrm{L}$. The MCL for As will be $10 \mu \mathrm{g} / \mathrm{L}$ in 2006. In four public-supply wells, As concentrations were measured above $10 \mu \mathrm{g} / \mathrm{L}$, with concentrations of 13.0, 17.2, 24.6 and $32.8 \mu \mathrm{g} / \mathrm{L}$ respectively. Barium was detected in 32 ground-water samples with concentrations ranging from 1 to $492 \mu \mathrm{g} / \mathrm{L}$. Beryllium was not detected in ground-water samples from public-supply wells. Boron was detected in 32 ground-water samples with concentrations ranging from 16 to $3,830 \mu \mathrm{g} / \mathrm{L}$; with 19 wells having concentrations of boron above the DLR of $100 \mu \mathrm{g} / \mathrm{L}$ with concentrations of between 120 and 3,830 $\mu \mathrm{g} / \mathrm{L}$. Cadmium was detected in 5 ground-water samples with concentrations ranging from an estimated concentration of $\mathrm{E} 0.03$ to a concentration of $0.05 \mu \mathrm{g} / \mathrm{L}$, all below the MCL of $5 \mu \mathrm{g} / \mathrm{L}$. Chromium was detected in 6 ground-water samples with concentrations ranging from an estimated value of (E) 0.4 to a concentration of $4.4 \mu \mathrm{g} / \mathrm{L}$; all below the MCL of $50 \mu \mathrm{g} / \mathrm{L}$. Cobalt was detected in 31 ground-water samples with concentrations ranging from 0.019 to $0.509 \mu \mathrm{g} / \mathrm{L}$. Copper was detected in 29 ground-water samples with concentrations ranging from an estimated value of (E) 0.2 to a concentration of $14.8 \mu \mathrm{g} / \mathrm{L}$; below the MCL of $1,000 \mu \mathrm{g} / \mathrm{L}$.

Iron was detected in 32 ground-water samples with concentrations ranging from an estimated value of (E) 4 to a value of $1,090 \mu \mathrm{g} / \mathrm{L}$. Seven public-supply wells had Fe concentrations above the SMCL of $300 \mu \mathrm{g} / \mathrm{L}$ with concentrations between 308 to $1,090 \mu \mathrm{g} / \mathrm{L}$. Lead was detected in 28 groundwater samples with concentrations ranging from an estimated value of (E) 0.05 to a concentration of $15.3 \mu \mathrm{g} / \mathrm{L}$. One public-supply well had a lead concentration of 15.3, above the California notification level (NL) of $15 \mu \mathrm{g} / \mathrm{L}$. Lithium was detected in 28 ground-water samples with concentrations ranging from 3 to $81 \mu \mathrm{g} / \mathrm{L}$. Manganese was detected in 28 groundwater samples with concentrations ranging from an estimated value of (E) 0.1 to a concentration of $1,220 \mu \mathrm{g} / \mathrm{L}$. Seventeen of the public-supply wells had concentrations above the Mn SMCL of $50 \mu \mathrm{g} / \mathrm{L}$. Mercury was not detected $(<0.001)$ in any of the public-supply wells.

Molybdenum was detected in 32 ground-water samples with concentrations ranging from an estimated value of $(\mathrm{E})$ 0.2 to a concentration of $20.3 \mu \mathrm{g} / \mathrm{L}$. Nickel was detected in
31 ground-water samples with concentrations ranging from an estimated value of (E) 0.05 to a concentration of $5.58 \mu \mathrm{g} / \mathrm{L}$. Selenium was detected in 12 ground-water samples with concentrations ranging from an estimated value of (E) 0.2 to a concentration of $2 \mu \mathrm{g} / \mathrm{L}$. Silver was detected in 2 groundwater samples with concentrations ranging from 0.26 to 0.52 $\mu \mathrm{g} / \mathrm{L}$. Strontium was detected in 32 ground-water samples with concentrations ranging from 29.8 to $440 \mu \mathrm{g} / \mathrm{L}$. Thallium was detected in 4 ground-water samples with concentrations ranging from an estimated value of (E) $0.03 \mu \mathrm{g} / \mathrm{L}$ to a concentration of $0.22 \mu \mathrm{g} / \mathrm{L}$; below the MCL of $2 \mu \mathrm{g} / \mathrm{L}$. Tungsten was detected in 6 ground-water samples with concentrations ranging from 0.6 to $2.3 \mu \mathrm{g} / \mathrm{L}$. Vanadium was detected in 30 ground-water samples with concentrations ranging from 0.2 to $19.6 \mu \mathrm{g} / \mathrm{L}$. Nine wells had Vanadium concentrations above 3 $\mu \mathrm{g} / \mathrm{L}$, the detection level for the purposes of reporting (DLR). Zinc was detected in 31 ground-water samples with concentrations ranging from an estimated value of (E) 0.6 to a concentration of $63.8 \mu \mathrm{g} / \mathrm{L}$. Uranium was detected in 26 ground-water samples with concentrations ranging from 0.04 to $3.53 \mu \mathrm{g} / \mathrm{L}$. When converted from mass units to activities using the standard conversion factor of $0.67 \mathrm{pCi} / \mu \mathrm{g}$, all uranium activities were below the DHS MCL of $20 \mathrm{pCi} / \mathrm{L}$.

Table 17 presents the results from the USGS NRP Boulder lab for total dissolved inorganic As and Fe, as well as the individual species As (III) and Fe (II) for samples collected in the NSF study unit; 4 samples from public supply wells had total As concentrations above the MCL of $10 \mu \mathrm{g} / \mathrm{L}$, with concentrations of 12.0, 16.2, 22.0 and 29.8, respectively. Three samples from public supply wells had concentrations of total iron above the SMCL of $300 \mu \mathrm{g} / \mathrm{L}$, with values of 301 , 313 and $900 \mu \mathrm{g} / \mathrm{L}$, respectively. These results agree well with samples from the same wells identified in table 16, which were analyzed at the USGS NWQL in Denver.

Table 18 presents $\mathrm{Cr}$ speciation analyses from the USGS NRP Boulder lab; total dissolved $\mathrm{Cr}$ and hexavalent $\mathrm{Cr}$ (VI). Values ranged from 0.1 to $15.6 \mu \mathrm{g} / \mathrm{L}$. None of the total $\mathrm{Cr}$ concentrations were above regulatory levels, however, 47 wells had $\mathrm{Cr}(\mathrm{VI})$ values above $1 \mu \mathrm{g} / \mathrm{L}$, the detection level for the purposes of reporting (DLR).

\section{Isotopes, Radioactivity, and Dissolved Gases}

Isotope activities, stable isotopes, and gross alpha/ beta radioactivity were determined in ground-water samples collected for the NSF GAMA study unit (table 19). Stable isotopes of water were collected at all 93 wells. Radium-226, radium-228, radon-222, alpha radioactivity (72-hour and 30 -day count), beta radioactivity (72-hour and 30-day count), and carbon isotopes were collected at 21 wells. Ground-water samples for tritium, analyzed at the USGS laboratory, were collected at 89 public-supply wells. 
Alpha radioactivity in 21 samples (table 19) ranged from below quantification limits $(<0.001 \mathrm{pCi} / \mathrm{L})$ to $2.2 \mathrm{pCi} / \mathrm{L}$ for 72-hour counts, and from below quantification limits $(<0.001$ $\mathrm{pCi} / \mathrm{L}$ ) to $3.9 \mathrm{pCi} / \mathrm{L}$ for 30 day counts; neither are above the alpha radioactivity MCL of $15 \mathrm{pCi} / \mathrm{L}$. Beta radioactivity in 21 samples ranged from below quantification limits $(<0.001 \mathrm{pCi} / \mathrm{L})$ to $20.2 \mathrm{pCi} / \mathrm{L}$ for 72 -hour counts, and from below quantification limits $(<0.001 \mathrm{pCi} / \mathrm{L})$ to $21.6 \mathrm{pCi} / \mathrm{L}$ in 30 -day counts. The MCL for beta radioactivity is $50 \mathrm{pCi} / \mathrm{L}$. Tritium was detected in 76 out of 89 samples with activities that ranged from below 1 to $9.9 \mathrm{pCi} / \mathrm{L}$; the MCL for tritium is $20,000 \mathrm{pCi} / \mathrm{L}$. Carbon-14, as percent modern carbon (pmc), was measured at 22 wells, and had values that ranged from 0.01 to 1.05 pmc. Radon-222 was detected in all 21 samples collected, and had activities ranging from 210 to $1,500 \mathrm{pCi} / \mathrm{L}$. Seventy-one percent (15 samples) of the radon-222 activities were above the proposed MCL of $300 \mathrm{pCi} / \mathrm{L}$. Radium-226 was detected in all 21 samples collected, however concentrations did not exceed $0.17 \mathrm{pCi} / \mathrm{L}$. Radium-228 was detected in 13 out of 21 samples, with a maximum concentration of $0.63 \mathrm{pCi} / \mathrm{L}$. No wells had activities above the combined radium-226 and radium-228 MCL of $5 \mathrm{pCi} / \mathrm{L}$.

Tritium and noble gas samples (analyzed at LLNL) were collected at 95 wells (table 20). Tritium, measured by the helium ingrowth method, was detected in 93 samples. Activities ranged from below 1 to $11.0 \mathrm{pCi} / \mathrm{L}$; the MCL for tritium is $20,000 \mathrm{pCi} / \mathrm{L}$. Noble gas concentrations and the helium isotope ratios (helium-3/helium-4) measured in each sample are presented in table 20.

The dissolved gases carbon dioxide, nitrogen, argon, oxygen, and methane were measured in ground-water samples from 4 production wells in the Valley and Plains study area, and 7 hydrothermal wells as part of the hydrothermal study (table 21). Dissolved gas concentrations in production-well ground water are low, do not adversely affect ground-water quality, and are not regulated for water-quality purposes.

\section{Microbial Constituents}

Microbial constituents were analyzed in 22 ground-water samples collected for the North San Francisco Bay GAMA study (table 22). The following microbial constituents were determined: total coliform and Escherichia coliform, and the viruses F-specific coliphage and somatic coliphage. Total coliform was detected in three wells, two in the Valley and Plains study area, and one in the Wilson Grove Formation Highlands study area. Counts ranged from an estimated 2 colonies/100 $\mathrm{mL}$ to 20 colonies $/ 100 \mathrm{~mL}$. MCLs for microbial constituents are based on reoccurring detection, and will be monitored during future sampling.

\section{Summary}

The NSF GAMA study assessed the ground-water quality of 89 public-supply wells across the $\sim 1,000 \mathrm{mi}^{2}$ study unit. Results from 84 randomized wells, statistically representative of the study unit, show that no anthropogenic constituents were detected at concentrations higher than those levels set for regulatory purposes. Naturally occurring constituents represent the only concentrations above regulatory thresholds for drinking-water supply, with concentrations of arsenic, manganese, radon-222, and microbiological contaminants in a small percentage of public-supply wells greater than recommended MCLs, and dissolved solids, iron and manganese above recommended SMCLs, boron and vanadium above the DLR, and lead above the NL.

Ground-water samples were analyzed for major and minor ions, trace elements, nutrients, volatile organic compounds (VOCs), pesticides, waste-water indicators, dissolved methane, nitrogen, carbon dioxide, and noble gases (in collaboration with Lawrence Livermore National Laboratory). Naturally occurring isotopes (tritium, carbon-14, and helium-4) also were measured in these samples to help interpret the source and age of the sampled ground water.

In this study, twenty-one of the 88 VOCs and gasoline additives and (or) oxygenates investigated were detected in ground-water samples, however, no concentrations observed were above established maximum contaminant levels (MCLs). Thirty-two percent of the randomized wells sampled during the North San Francisco Bay GAMA study had at least a single detection of VOCs or gasoline additives and (or) oxygenates. The most frequently detected compounds were chloroform found in 12 of 84 randomized wells sampled (14 percent), carbon disulfide in 8 of 84 randomized wells sampled (10 percent), and toluene in 4 of 84 randomized wells sampled ( 5 percent). Trihalomethanes were the most frequently detected class of VOCs.

Nine of the 122 pesticides and pesticide degradates investigated were detected in ground-water samples, however, none were above MCLs. Seventeen percent of the 84 randomized wells sampled during the NSF GAMA study had at least a single detection of pesticides and pesticide degradates. Herbicides were the most frequently detected class of pesticides. The most frequently detected compound was simazine, detected in water from 8 of the 84 (10 percent) of the randomized wells. Chlordiamino-s-triazine and deisopropyl atrazine were both found in 2 of the 84 ( 2 percent) randomized wells sampled. 
Thirteen waste-water indicators were detected in groundwater samples in the NSF study unit. Twenty-six percent of the wells sampled for waste-water indicators had at least a single detection. Isophorone, a solvent and the most frequently detected waste-water indicator compound, was detected in 6 out of 84 randomized wells ( 7 percent of the wells). Bisphenol-A (plastic resins; flame retardant), caffeine (beverages), and indole (pesticide, fragrance in coffee) were each detected in 3 out of 84 randomized wells (4 percent of the wells).

Major and minor ion and dissolved solids (DS) samples were collected at 33 public-supply wells, concentrations of DS were above the secondary maximum contaminant level (SMCL) in three samples. Ground-water samples from 32 public-supply wells were analyzed for trace elements. Arsenic concentrations in 4 public-supply wells were above the MCL of $10 \mu \mathrm{g} / \mathrm{L}$, boron concentrations were above the DLR of 100 $\mu \mathrm{g} / \mathrm{L}$ in 19 samples, iron concentrations were above the SMCL of $300 \mu \mathrm{g} / \mathrm{L}$ in seven samples, lead concentration was above the California notification level (NL) of $15 \mu \mathrm{g} / \mathrm{L}$ in one pubicsupply well sample, manganese concentrations were above the SMCL of $50 \mu \mathrm{g} / \mathrm{L}$ in 17 wells, vanadium concentrations were above the DLR of $3 \mu \mathrm{g} / \mathrm{L}$ in 9 wells, and chromium (VI) concentrations were above the DLR of $1 \mu \mathrm{g} / \mathrm{L}$ in 47 wells.

Radon-222 was detected in all 21 ground-water samples collected, with activities ranging from 210 to 1,500 pico Curies per liter $(\mathrm{pCi} / \mathrm{L})$. Fifteen samples were above the proposed MCL of $300 \mathrm{pCi} / \mathrm{L}$.

Microbial constituents were analyzed in 22 ground-water samples. Total coliform was detected in three wells, two in the Valley and Plains study area, and one in the Wilson Grove Formation Highlands study area. Counts ranged from 2 colonies per $100 \mathrm{~mL}$ to 20 colonies per $100 \mathrm{~mL}$. MCLs for microbial constituents are based on reoccurring detection, and will be monitored during future sampling.

\section{References}

American Society for Testing and Materials, 1998a, Annual book of ASTM standards: water and environmental technology: v. 11.02 Water (II), 1048 p.

American Society for Testing and Materials, 1998b, Annual book of ASTM standards: water and environmental technology: v. 11.01 Water (I), $890 \mathrm{p}$.

Ball, J. W. and McClesky, R. B., 2003, A new cation-exchange method for accurate field speciation of hexavalent chromium: Talanta, v. 61, p. 305-313.

Belitz, K., Dubrovsky, N. M., Burow, K., Jurgens, B. and Johnson, T., 2003, Framework for a ground-water quality monitoring and assessment program for California: U.S. Geological Survey Water-Resources Investigations Report 03-4166, $78 \mathrm{p}$.
Brenton, R. W. and Arnett, T. L., 1993, Methods of analysis by the U.S. Geological Survey National Water-Quality Laboratory-Determination of dissolved organic carbon by UV-promoted persulfate oxidation and infrared spectrometry: U.S. Geological Survey Open-File Report 92-480, 12 p.

CAL. WATER $\S \S 10780-10782.3$, State of California: accessed on August 28, 2005, at: http://www.leginfo.ca.gov/ cgi-bin/waisgate? WAISdocID $=0947433797+0+0+0 \&$ WAIS action $=$ retrieve .

California Dept. Water Resources, 2003, California's Groundwater Bulletin 118, $246 \mathrm{p}$.

Cardwell, G. T., 1958, Geology and ground water in the Santa Rosa and Petaluma Valley areas Sonoma County California: U.S. Geological Survey Water-Supply Paper 1427, 273 p.

Childress, C. J. O., Foreman, W. T., Connor, B. F. and Maloney, T. J., 1999, New reporting procedures based on longterm method detection levels and some considerations for interpretations of water-quality data provided by the U.S. Geological Survey National Water Quality Laboratory: U.S. Geological Survey Open-File Report 99-193, p. 99-193.

Clarke, W. B., Jenkins, W. J. and Top, Z., 1976, Determination of tritium by mass spectrometric measurement of He-3: International Journal of Applied Radiation and Isotopes, v. 27 , p. $515-522$.

Connor, B. F., Rose, D. L., Noriega, M. C., Murtagh, L. K. and Abney, S. R., 1998, Methods of analysis by the U.S. Geological Survey National Water Quality Laboratory: Determination of 86 volatile organic compounds in water by gas chromatography/mass spectrometry, including detections less than reporting limits: U.S. Geological Survey OpenFile Report 97-829, 78 p.

Coplen, T. B., Wildman, J. D. and Chen, J., 1991, Improvements in the gaseous hydrogen-water equilibrium technique for hydrogen isotope analysis: Analytical Chemistry, v. 63, p. $910-912$.

Coplen, T. B., 1994, Reporting of stable hydrogen, carbon, and oxygen isotopic abundances: Pure and Applied Chemistry, v. 66, p. $273-276$.

Donahue, D. J., Linick, T. W. and Jull, A. J. T., 1990, Ratio and background corrections for accelerator mass spectrometry radiocarbon measurements: Radiocarbon, v. 32, p. $135-142$.

Faye, R. E., 1973, Ground-water Hydrology of Northern Napa Valley, California: U.S. Geological Survey Water-Resources Investigations Report 13-73, 64 p.

Fishman, M. J. and Friedman, L. C., 1989, Methods for determination of inorganic substances in water and fluvial sediments: U.S. Geological Survey Techniques of WaterResources Investigations, book 5, chap. A1, 545 p. 
Fishman, M. J., 1993, Methods of analysis by the U.S. Geological Survey National Water Quality Laboratory-Determination of inorganic and organic constituents in water and fluvial sediments: U.S. Geological Survey Open-File Report 93-125, 217 p.

Fox, K., 1983, Tectonic setting of late Miocene, Pliocene, and Pleistocene rocks in part of the Coast Ranges north of San Francisco, California: Geological Survey Professional Paper, v. 1239, p. 33.

Friedman, L.C., and Erdmann, D.E., eds., 1982, Quality assurance practices for the chemical and biological analyses of water and fluvial sediments: U.S. Geological Survey Techniques of Water-Resources Investigations, book 5, chap. A6, 181 p.

Furlong, E. T., Anderson, B. D., Werner, S. L., Soliven, P. P., Coffey, L. J. and Burkhardt, M. R., 2001, Methods of analysis by the U.S. Geological Survey National Water Quality Laboratory-determination of pesticides in water by graphitized carbon-based solid-phase extraction and highperformance liquid chromatography/mass spectrometry: U.S. Geological Survey Water-Resources Investigations Report 01-4134, 73 p.

Garbarino, J. R., 1999, Methods of analysis by the U.S. Geological Survey National Water Quality Laboratory Determination of dissolved arsenic, boron, lithium, selenium, strontium, thallium, and vanadium using inductively coupled plasma-mass spectrometry: U.S. Geological Survey Open-File Report 99-093, 31 p.

Garbarino, J. R. and Damrau, D. L., 2001, Methods of analysis by the U.S. Geological Survey National Water Quality Laboratory-Determination of organic plus inorganic mercury in filtered and unfiltered natural water with cold vapor-atomic fluorescence spectrometry: U.S. Geological Survey Water-Resources Investigations Report 01-4132, $16 \mathrm{p}$.

Hautman, D. P., Munch, D. J., Eaton, A. D. and Haghani, A. W., 1999, Method 314.0 Determination of perchlorate in drinking water using ion chromatography, revision 1.0: U.S. Environmental Protection Agency, accessed on April 20, 2005, at: http://www.epa.gov/safewater/methods/met314. $p d f$.

Johnson, F. A., 1934, Geology of the Merced, Pliocene, formation north of San Francisco Bay, California (Ph.D. Thesis, University of California), unknown pagination.

Jull, A. J. T., Burr, G. S., McHargue, L. R., Lange, T. E., Lifton, N. A., Beck, J. W., J., D. D. and Lal, D., 2004, New frontiers in dating of geological, paleoclimatic and anthropological applications using accelerator mass spectrometric measurements of $14 \mathrm{C}$ and $10 \mathrm{Be}$ in diverse samples: Global \& Planetary Change, v. 41, p. 309-323.
Kana, T. M., Darkangelo, C., Hunt, M. D., Oldham, J. B., Bennett, G. E. and Cornwell, J. C., 1994, Membrane inlet mass spectrometer for rapid high-precision determination of N2, O2, and Ar in environmental water samples: Analytical Chemistry, v. 66, p. 4166-4170.

Koterba, M. T., Wilde, F. D. and Lapham, W. W., 1995, Ground-water data-collection protocols and procedures for the National Water-Quality Assessment Program: collection and documentation of water-quality samples and related data: U.S. Geological Survey Open-File Report 95-399, $113 \mathrm{p}$.

Kulongoski, J. T. and Belitz, K., 2004, Ground-water ambient monitoring and assessment program: U.S. Geological Survey Fact Sheet 2004-3088, 2 p.

McCleskey, R. B., Nordstrom, D. K. and Ball, J. W., 2003, Metal interferences and their removal prior to the determination of $\mathrm{As}(\mathrm{T})$ and $\mathrm{As}(\mathrm{III})$ in acid mine waters by hydride generation atomic absorption spectrometry: U.S. Geological Survey Water-Resources Investigations Report 03-4117: v. p. 14.

Moran, J. E., Hudson, G. B., Eaton, G. F. and Leif, R., 2002, A contamination vulnerability assessment for the LivermoreAmador and Niles Cone Groundwater Basins: UCRLAR-148831, 25 p.

Osmont, V. C., 1905, A geological section of the Coast Ranges north of the Bay of San Francisco: University of California: Department of Geology Bulletin, v. 4, p. 39-87.

Patton, C. J. and Kryskalla, J. R., 2003, Methods of analysis by the U.S. Geological Survey National Water-Quality Laboratory: evaluation of alkaline persulfate digestion as an alternative to Kjeldahl Digestion for determination of total and dissolved nitrogen and phosphorus in water: U.S. Geological Survey Water-Resources Investigations Report 03-4174, 33 p.

Rose, D. L. and Sandstrom, M. W., 2003, Methods of analysis by the U.S. Geological Survey National Water Quality Laboratory-determination of gasoline oxygenates, Selected degradates, and BTEX in water by heated purge and trap/ gas chromatography/mass spectrometry: U.S. Geological Survey Water-Resources Investigations Report 03-4079, $31 \mathrm{p}$.

Sandstrom, M. W., Stroppel, M. E., Foreman, W. T. and Schroeder, M. P., 2001, Methods of analysis by the U.S. Geological Survey National Water Quality Laboratory-determination of moderate-use pesticides and selected degradates in water by C-18 solid-phase extraction and gas chromatography/mass spectrometry: U.S. Geological Survey WaterResources Investigations Report 01-4098, 70 p. 
Scott, J. C., 1990, Computerized stratified random site selection approaches for design of a ground-water quality sampling network: U.S. Geological Survey Water-Resources Investigations Report 90-4101, 109 p.

Thatcher, L. L., Janzer, V. J. and Edwards, K. W., 1977, Methods for the determination of radioactive substances in water: U.S. Geological Survey Techniques of Water-Resources Investigations, chapter A5, $95 \mathrm{p}$.

Timme, P. J., 1995, National Water Quality Laboratory 1995 services catalog: U.S. Geological Survey Open-File Report 95-352, 120 p.

To, T. B., Nordstrom, D. K., Cunningham, K. M., Ball, J. W. and McCleskey, R. B., 1998, New method for the direct determination of dissolved Fe(III) concentration in acid mine waters: Environmental Science \& Technology, v. 33, p. 807-812.

U.S. Environmental Protection Agency, 1980, Prescribed procedures for measurement of radioactivity in drinking water (EPA/600/4-80-032), 6 p.

U.S. Environmental Protection Agency, 1996, Method 8270C, semivolatile organic compounds by gas chromatography/ mass spectrometry, revision 3: U.S. Environmental Protection Agency, 54 p.

U.S. Environmental Protection Agency, 2001, Method 1601: Male-specific $(\mathrm{F}+)$ and somatic coliphage in water by twostep enrichment procedure, $32 \mathrm{p}$.
U.S. Environmental Protection Agency, 2002a, Guidelines for establishing procedures for the analysis of pollutants: U.S. Code of Federal Regulations, Title 40, 136 p.

U.S. Environmental Protection Agency, 2002b, Method 1604Total coliforms and Escherichia coli in water by membrane filtration using a simultaneous detection technique (MI medium), $14 \mathrm{p}$.

U.S. Geological Survey, variously dated, National field manual for the collection of water-quality data: U.S. Geological Survey Techniques of Water-Resources Investigations, book 9, chaps. A1-A9, available online at http://pubs.water.usgs. gov/twri9A.

Weiss, R. F., 1968, Piggyback sampler for dissolved gas studies on sealed water samples: Deep Sea Research, v. 15, p. $721-735$.

Zaugg, S. D., Smith, S. G., Schroeder, M. P., Barber, L. B. and Burkhardt, M. R., 2002, Methods of analysis by the U.S. Geological Survey National Water Quality Laboratorydetermination of wastewater compounds by polystyrenedivinylbenzene solid-phase extraction and capillary-column gas chromatography/mass spectrometry: U.S. Geological Survey Water-Resources Investigations Report 01-4186, $37 \mathrm{p}$. 

Tables 
Table 1. Identification, sampling and construction information for wells sampled for the North San Francisco Bay Ground-Water Ambient Monitoring and Assessment (GAMA) study, California, August to November 2004.

[ft, foot; LSD, land surface datum; NA, not available; ND, no data; NSFVP, Valley and Plains study area; NSFVPFP, Valley and Plains flow-path well; NSFVOL, Volcanic Highlands study area; NSFWG, Wilson Grove Formation Highlands study area; NSFWGFP, Wilson Grove Formation Highlands flow-path well; NSFHOT, hydrothermal study]

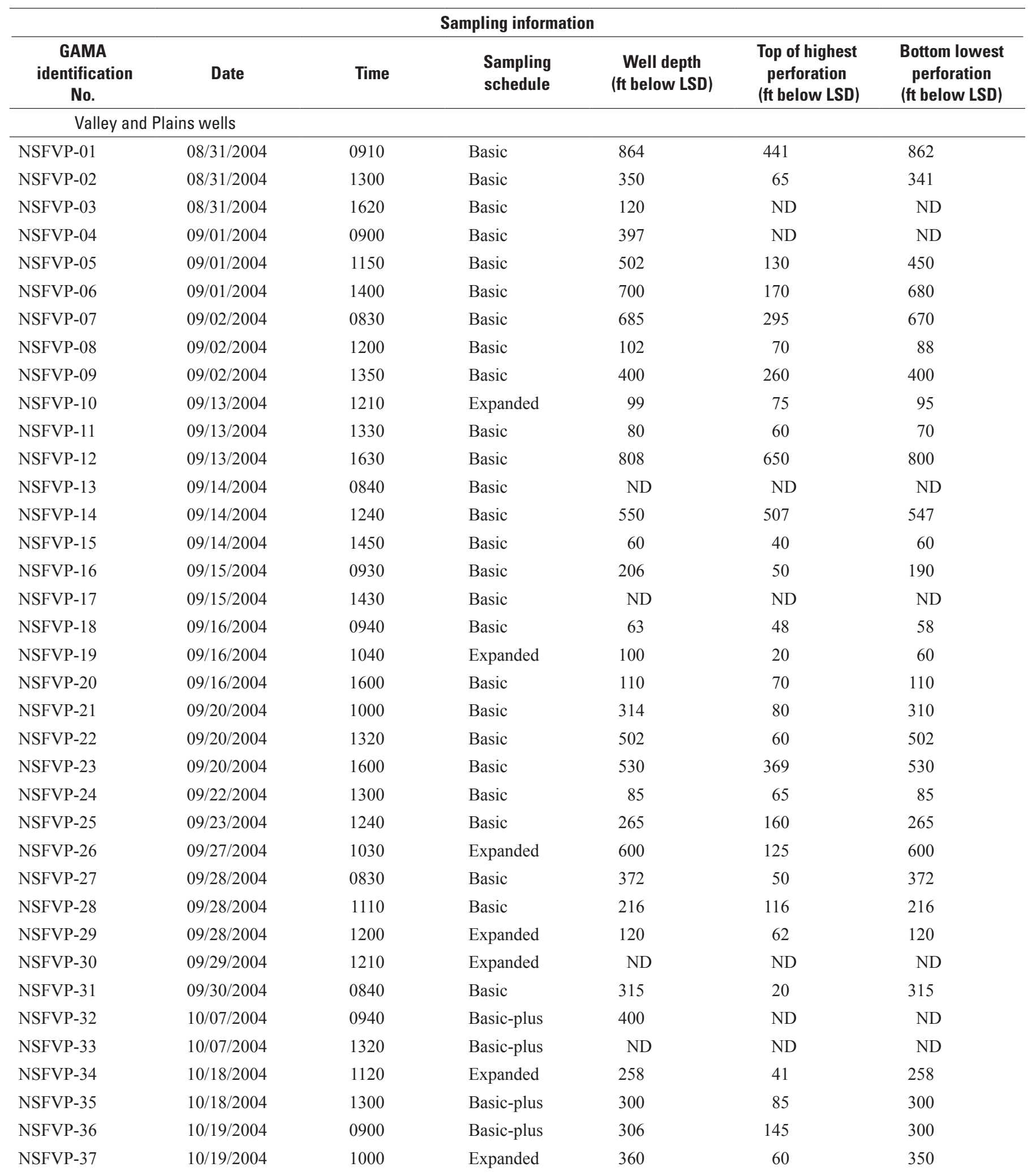


Table 1. Identification, sampling and construction information for wells sampled for the North San Francisco Bay Ground-Water Ambient Monitoring and Assessment (GAMA) study, California, August to November 2004-Continued.

[ft, foot; LSD, land surface datum; NA, not available; ND, no data; NSFVP, Valley and Plains study area; NSFVPFP, Valley and Plains flow-path well; NSFVOL, Volcanic Highlands study area; NSFWG, Wilson Grove Formation Highlands study area; NSFWGFP, Wilson Grove Formation Highlands flow-path well; NSFHOT, hydrothermal study]

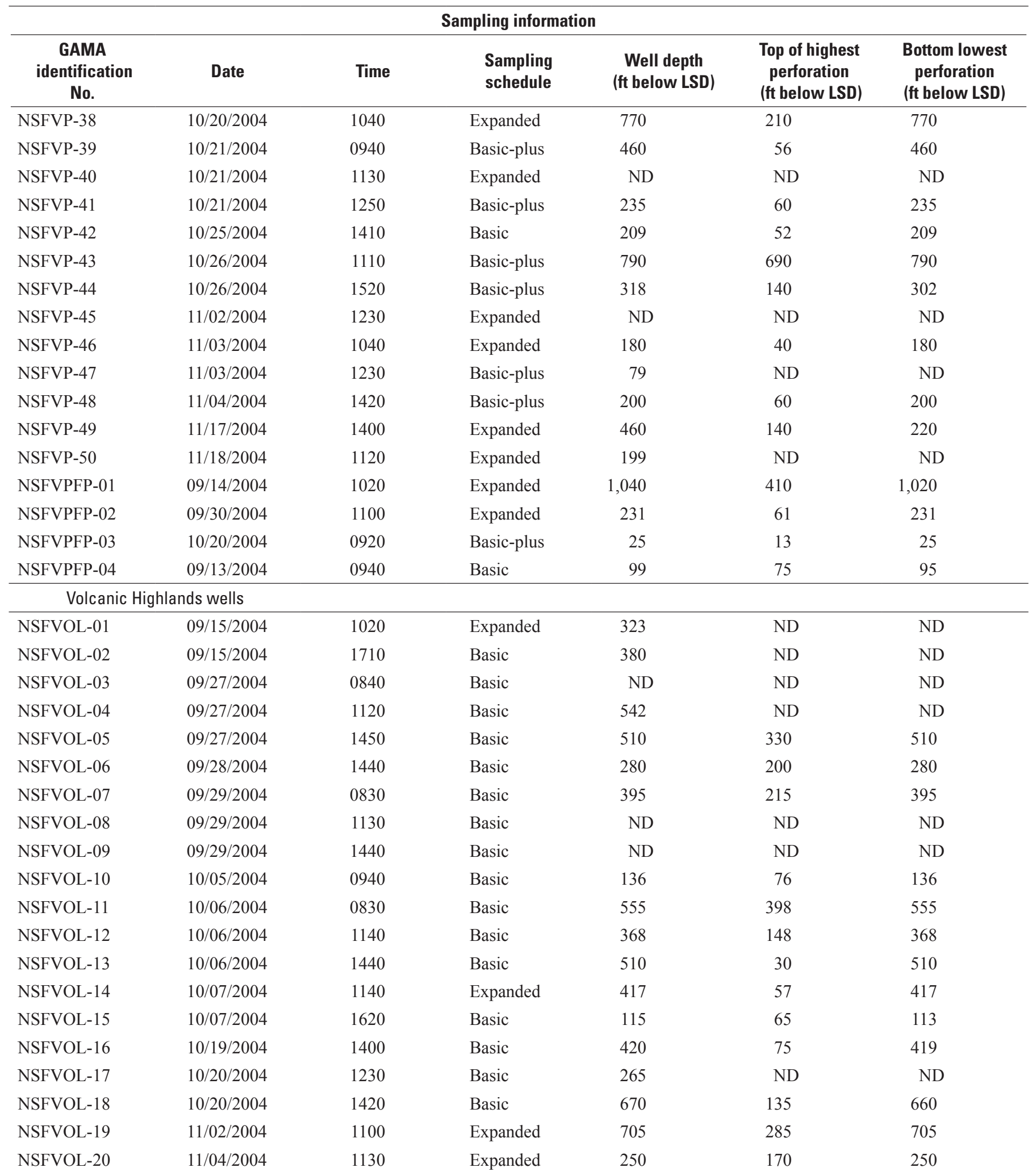


Table 1. Identification, sampling and construction information for wells sampled for the North San Francisco Bay Ground-Water Ambient Monitoring and Assessment (GAMA) study, California, August to November 2004_Continued.

[ft, foot; LSD, land surface datum; NA, not available; ND, no data; NSFVP, Valley and Plains study area; NSFVPFP, Valley and Plains flow-path well; NSFVOL, Volcanic Highlands study area; NSFWG, Wilson Grove Formation Highlands study area; NSFWGFP, Wilson Grove Formation Highlands flow-path well; NSFHOT, hydrothermal study]

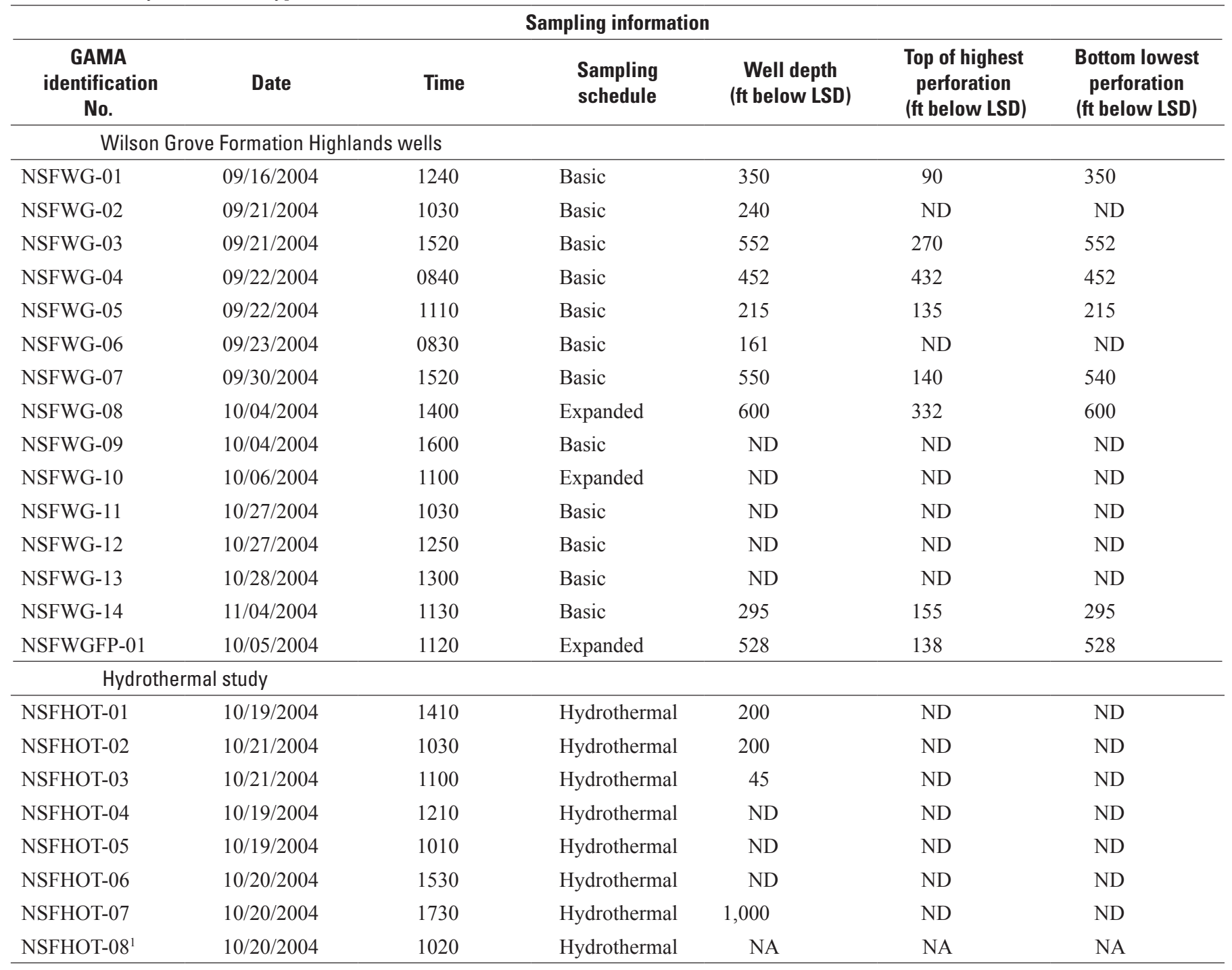

${ }^{1}$ Hydrothermal spring. 
Table 2A. Volatile organic compounds and gasoline additives and (or) oxygenates, primary use or source, Chemical Abstract Service (CAS) number, and laboratory reporting level (LRL) for the U.S. Geological Survey's National Water Quality Laboratory analytical schedule 2020.

[ $\mu \mathrm{g} / \mathrm{L}$, micrograms per liter]

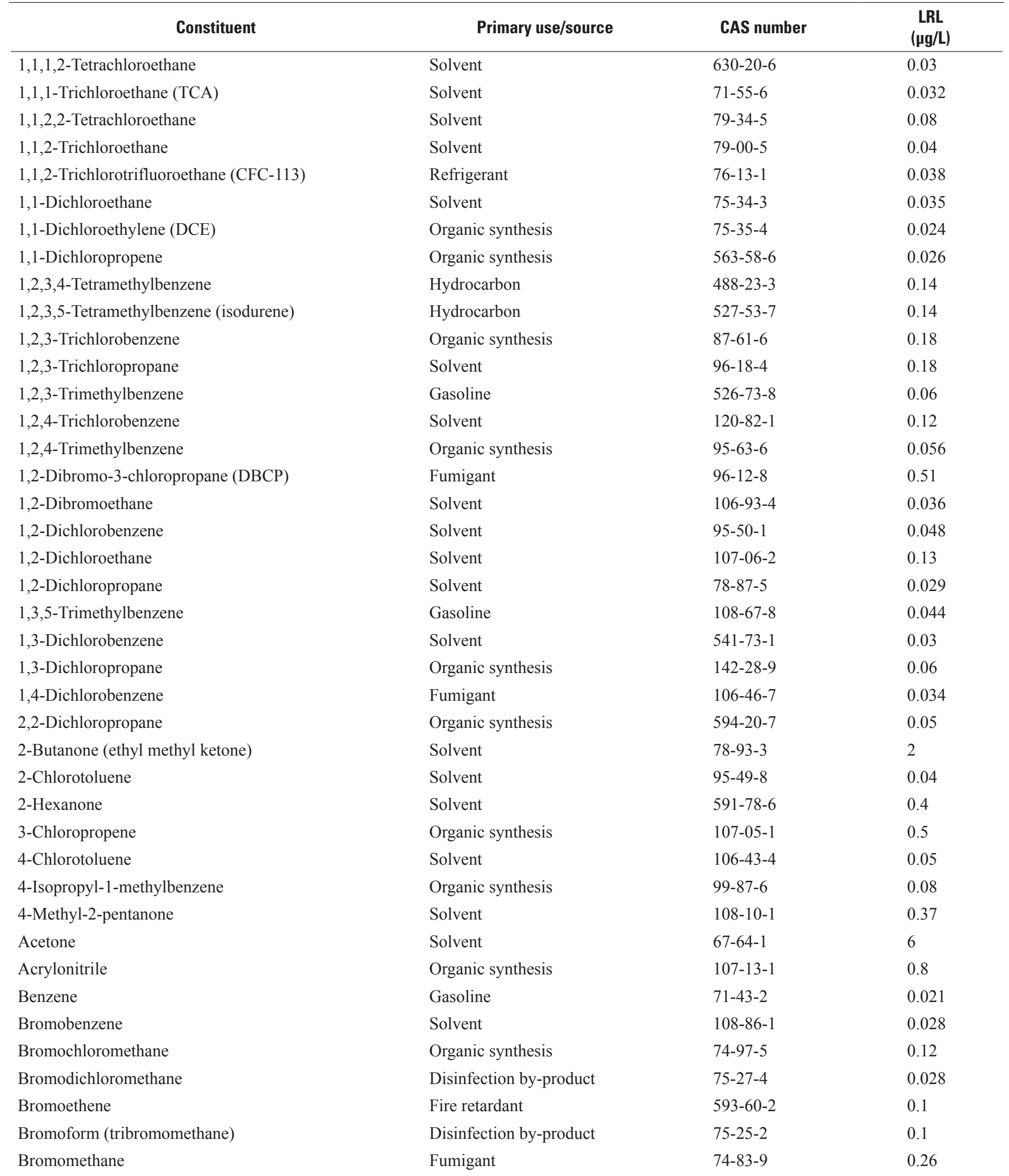


Table 2A. Volatile organic compounds and gasoline additives and (or) oxygenates, primary use or source, Chemical Abstract Service (CAS) number, and laboratory reporting level (LRL) for the U.S. Geological Survey's National Water Quality Laboratory analytical schedule 2020-Continued.

$[\mu \mathrm{g} / \mathrm{L}$, micrograms per liter]

\begin{tabular}{|c|c|c|c|}
\hline Constituent & Primary use/source & CAS number & $\begin{array}{c}\text { LRL } \\
(\mu \mathrm{g} / \mathrm{L})\end{array}$ \\
\hline Butylbenzene & Organic synthesis & $104-51-8$ & 0.12 \\
\hline Chlorobenzene & Solvent & $108-90-7$ & 0.028 \\
\hline Chloroethane & Solvent & $75-00-3$ & 0.12 \\
\hline cis-1,2-Dichloroethylene & Solvent & $156-59-2$ & 0.024 \\
\hline cis-1,3-Dichloropropene & Fumigant & $10061-01-5$ & 0.05 \\
\hline Dibromochloromethane & Disinfection by-product & $124-48-1$ & 0.1 \\
\hline Dibromomethane & Solvent & $74-95-3$ & 0.05 \\
\hline Diisopropyl ether & Gasoline & $108-20-3$ & 0.1 \\
\hline Ethyl methacrylate & Organic synthesis & $97-63-2$ & 0.18 \\
\hline Ethyl tert-butyl ether (ETBE) & Gasoline & $637-92-3$ & 0.03 \\
\hline Ethylbenzene & Gasoline & $100-41-4$ & 0.03 \\
\hline Hexachlorobutadiene & Organic synthesis & $87-68-3$ & 0.14 \\
\hline Hexachloroethane & Solvent & $67-72-1$ & 0.14 \\
\hline Isopropylbenzene & Organic synthesis & $98-82-8$ & 0.038 \\
\hline$m$-plus $p$-Xylene & Gasoline & $108-38-3 / 106-42-3$ & 0.06 \\
\hline Methyl acrylate & Organic synthesis & $96-33-3$ & 1 \\
\hline$n$-Propylbenzene & Solvent & $103-65-1$ & 0.042 \\
\hline$o$-Ethyl toluene & Hydrocarbon & 611-14-3 & 0.06 \\
\hline$o$-Xylene & Gasoline & $95-47-6$ & 0.038 \\
\hline sec-Butylbenzene & Organic synthesis & $135-98-8$ & 0.06 \\
\hline Styrene & Organic synthesis & $100-42-5$ & 0.042 \\
\hline tert-Amyl methyl ether & Gasoline & $994-05-8$ & 0.04 \\
\hline tert-Butylbenzene & Organic synthesis & $98-06-6$ & 0.06 \\
\hline Tetrachloroethylene (PCE) & Solvent & $127-18-4$ & 0.03 \\
\hline Tetrachloromethane (carbon tetrachloride) & Solvent & $56-23-5$ & 0.06 \\
\hline Tetrahydrofuran & Solvent & $109-99-9$ & 1 \\
\hline
\end{tabular}


Table 2A. Volatile organic compounds and gasoline additives and (or) oxygenates, primary use or source, Chemical Abstract Service (CAS) number, and laboratory reporting level (LRL) for the U.S. Geological Survey's National Water Quality Laboratory analytical schedule 2020-Continued.

$[\mu \mathrm{g} / \mathrm{L}$, micrograms per liter]

\begin{tabular}{|c|c|c|c|}
\hline Constituent & Primary use/source & CAS number & $\begin{array}{c}\text { LRL } \\
(\mu \mathrm{g} / \mathrm{L})\end{array}$ \\
\hline Toluene & Gasoline & $108-88-3$ & 0.02 \\
\hline trans-1,2-Dichloroethylene & Solvent & $156-60-5$ & 0.032 \\
\hline trans-1,3-Dichloropropene & Fumigant & $10061-02-6$ & 0.09 \\
\hline trans-1,4-Dichloro-2-butene & Organic synthesis & $110-57-6$ & 0.7 \\
\hline Trichloroethylene (TCE) & Solvent & 79-01-6 & 0.038 \\
\hline Trichlorofluoromethane (CFC-11) & Refrigerant & $75-69-4$ & 0.08 \\
\hline Vinyl chloride & Organic synthesis & $75-01-4$ & 0.08 \\
\hline
\end{tabular}

Table 2B. Gasoline oxygenates and (or) gasoline oxygenate degradates, primary use or source, Chemical Abstract Service (CAS) number, and laboratory reporting level (LRL) for the U.S. Geological Survey's National Water Quality Laboratory analytical schedule 4024. $[\mu \mathrm{g} / \mathrm{L}$, micrograms per liter]

\begin{tabular}{|c|c|c|c|}
\hline Constituent & Primary use/source & CAS number & $\begin{array}{l}\text { LRL } \\
(\mu \mathrm{g} / \mathrm{L})\end{array}$ \\
\hline Acetone & Degradate & $67-64-1$ & 1.2 \\
\hline Diisopropyl ether & Gasoline oxygenate & $108-20-3$ & 0.08 \\
\hline Ethyl tert-butyl ether (ETBE) & Gasoline oxygenate & $637-92-3$ & 0.1 \\
\hline Methyl acetate & Degradate & $79-20-9$ & 0.4 \\
\hline tert-Amyl alcohol & Degradate & $75-85-4$ & 0.43 \\
\hline tert-Butyl alcohol & Degradate & $75-65-0$ & 1 \\
\hline tert-Butyl methyl ether (MTBE) & Gasoline oxygenate & $1634-04-4$ & 0.08 \\
\hline tert-Amyl methyl ether & Gasoline oxygenate & $994-05-8$ & 0.07 \\
\hline
\end{tabular}


Table 2C. Pesticides and pesticide degradates, primary use or source, Chemical Abstract Service (CAS) number, and laboratory reporting level (LRL) for the U.S. Geological Survey's National Water Quality Laboratory analytical schedule 2003.

[NA, not available; $\mu \mathrm{g} / \mathrm{L}$, micrograms per liter]

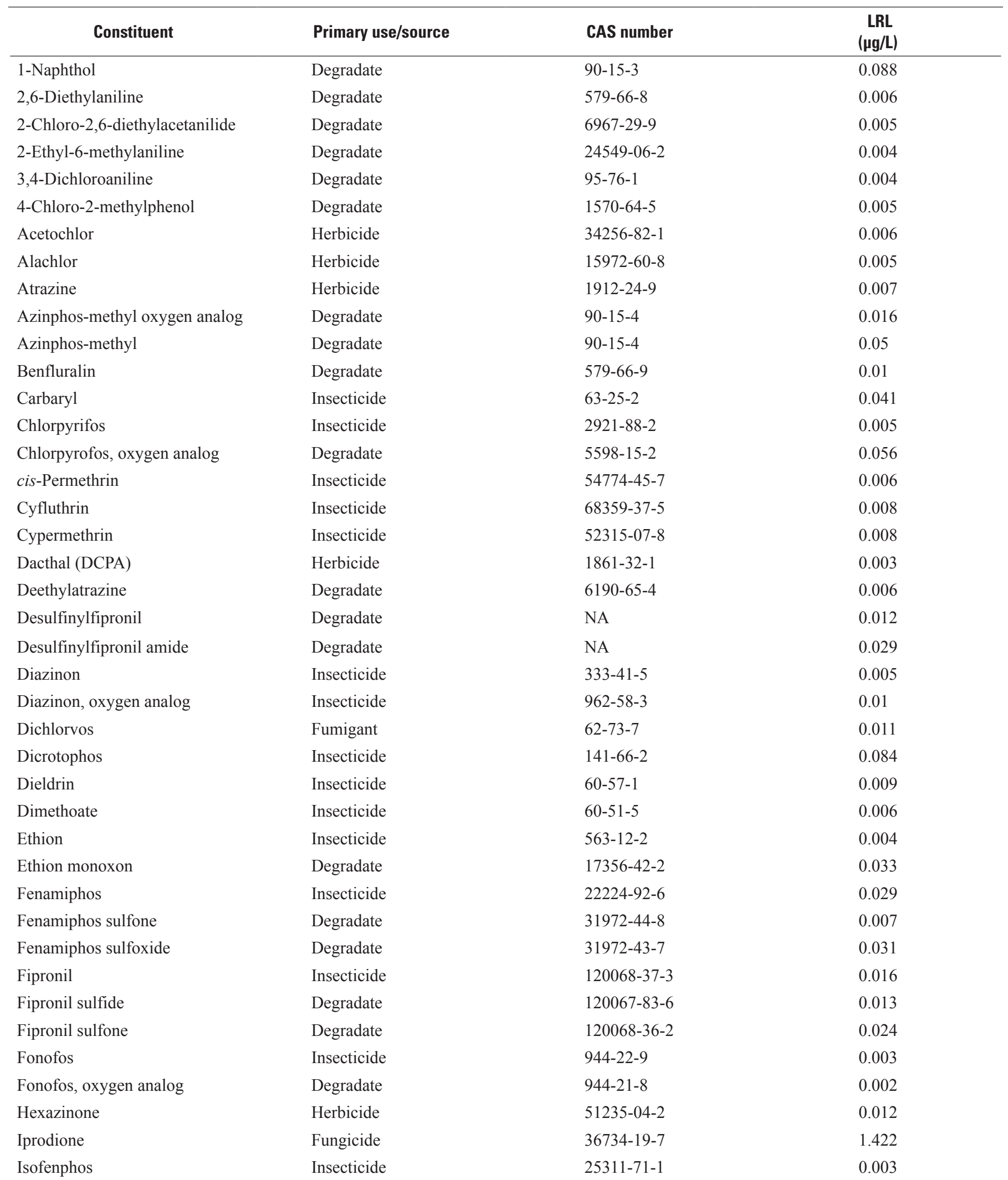


Table 2C. Pesticides and pesticide degradates, primary use or source, Chemical Abstract Service (CAS) number, and laboratory reporting level (LRL) for the U.S. Geological Survey's National Water Quality Laboratory analytical schedule 2003—Continued.

[NA, not available; $\mu \mathrm{g} / \mathrm{L}$, micrograms per liter]

\begin{tabular}{llll}
\hline \multicolumn{1}{c}{ Constituent } & Primary use/source & CAS number & $\begin{array}{c}\text { LRL } \\
\text { ( } \mathbf{g g} / \mathbf{L})\end{array}$ \\
\hline Malaoxon & Degradate & $1634-78-2$ & 0.008 \\
Malathion & Insecticide & $121-75-5$ & 0.027 \\
Metalaxyl & Fungicide & $57837-19-1$ & 0.005 \\
Methidathion & Insecticide & $950-37-8$ & 0.005 \\
Metolachlor & Herbicide & $51218-45-2$ & 0.013 \\
Metribuzin & Herbicide & $21087-64-9$ & 0.006 \\
Myclobutanil & Fungicide & $88671-89-0$ & 0.008 \\
Paraoxon-methyl & Degradate & $950-35-6$ & 0.029 \\
Parathion-methyl & Insecticide & $298-00-0$ & 0.015 \\
Pendimethalin & Herbicide & $40487-42-1$ & 0.022 \\
Phorate & Insecticide & $298-02-2$ & 0.011 \\
Phorate oxygen analog & Degradate & $2600-69-3$ & 0.097 \\
Phosmet & Insecticide & $732-11-6$ & 0.007 \\
Phosmet oxon & Degradate & $3735-33-9$ & 0.055 \\
Prometon & Herbicide & $1610-18-0$ & 0.005 \\
Prometryn & Herbicide & $7287-19-6$ & 0.005 \\
Propyzamide & Herbicide & $23950-58-5$ & 0.004 \\
Simazine & Herbicide & $122-34-9$ & 0.005 \\
Tebuthiuron & Herbicide & $34014-18-1$ & 0.016 \\
Terbufos & Insecticide & $13071-79-9$ & 0.017 \\
Terbufos oxygen analog sulfone & Degradate & $56070-15-6$ & 0.067 \\
Terbuthylazine & Herbicide & $5915-41-3$ & 0.010 \\
Trifluralin & Herbicide & $1582-09-8$ & 0.009 \\
\hline
\end{tabular}


Table 2D. Pesticides, pesticide degradates and caffiene, primary use or source, Chemical Abstract Service (CAS) number, and laboratory reporting level (LRL) for the U.S. Geological Survey's National Water Quality Laboratory analytical schedule 2060.

$[\mu \mathrm{g} / \mathrm{L}$, micrograms per liter]

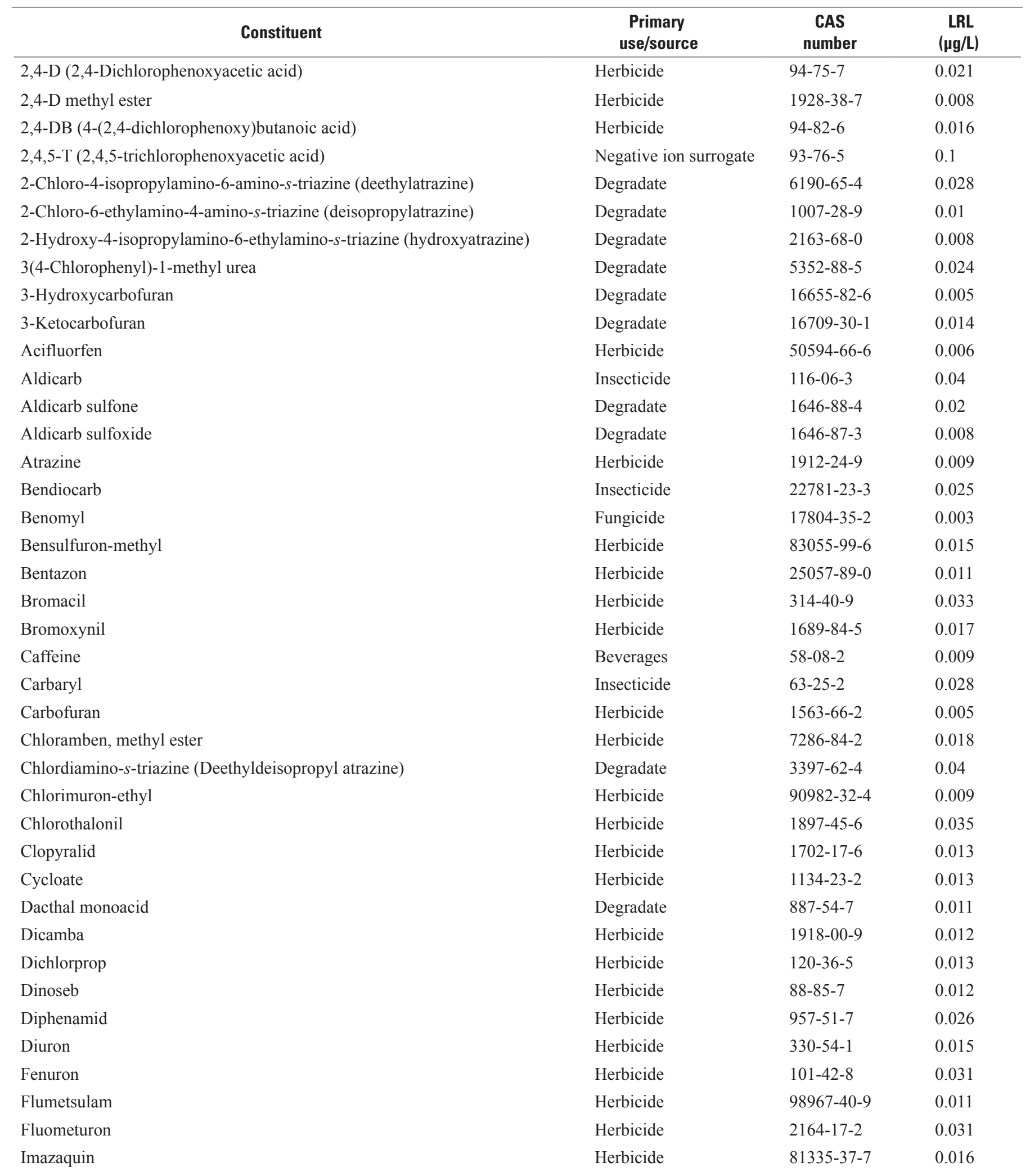


Table 2D. Pesticides, pesticide degradates, and caffiene, primary use or source, Chemical Abstract Service (CAS) number, and laboratory reporting limits (LRLs) for the U.S. Geological Survey's National Water Quality Laboratory analytical schedule 2060 - Continued.

$[\mu \mathrm{g} / \mathrm{L}$, micrograms per liter]

\begin{tabular}{|c|c|c|c|}
\hline Constituent & $\begin{array}{c}\text { Primary } \\
\text { use/source }\end{array}$ & $\begin{array}{c}\text { CAS } \\
\text { number }\end{array}$ & $\begin{array}{c}\text { LRL } \\
\text { ( } \mu \mathrm{g} / \mathrm{L})\end{array}$ \\
\hline Imazethapyr & Herbicide & $81335-77-5$ & 0.017 \\
\hline Imidacloprid & Insecticide & $138261-41-3$ & 0.006 \\
\hline Linuron & Herbicide & $330-55-2$ & 0.014 \\
\hline MCPA (2-methyl-4-chlorophenoxyacetic acid) & Herbicide & $94-74-6$ & 0.016 \\
\hline MCPB (2-methyl-4-chlorophenoxy butyric acid) & Herbicide & $94-81-5$ & 0.015 \\
\hline Metalaxyl & Fungicide & $57837-19-1$ & 0.02 \\
\hline Methiocarb & Insecticide & $2032-65-7$ & 0.008 \\
\hline Methomyl & Insecticide & $16752-77-5$ & 0.004 \\
\hline Metsulfuron methyl & Herbicide & 74223-64-6 & 0.025 \\
\hline Neburon & Herbicide & $555-37-3$ & 0.012 \\
\hline Nicosulfuron & Herbicide & 111991-09-4 & 0.013 \\
\hline Norflurazon & Herbicide & $27314-13-2$ & 0.016 \\
\hline Oryzalin & Herbicide & $19044-88-3$ & 0.017 \\
\hline Oxamyl & Insecticide & $23135-22-0$ & 0.012 \\
\hline Picloram & Herbicide & 6607 & 0.019 \\
\hline Propham & Herbicide & $122-42-9$ & 0.009 \\
\hline Propiconazole & Fungicide & $60207-90-1$ & 0.021 \\
\hline Propoxur & Insecticide & $114-26-1$ & 0.008 \\
\hline Siduron & Herbicide & $1982-49-6$ & 0.016 \\
\hline Sulfometuron-methyl & Herbicide & $74222-97-2$ & 0.008 \\
\hline Tebuthiuron & Herbicide & $34014-18-1$ & 0.006 \\
\hline Terbacil & Herbicide & $5902-51-2$ & 0.009 \\
\hline Tribenuron-methyl & Herbicide & $101200-48-0$ & 0.008 \\
\hline Triclopyr & Herbicide & $55335-06-3$ & 0.022 \\
\hline
\end{tabular}


Table 2E. Waste-water indicator constituents, primary use or source, Chemical Abstract Service (CAS) number, and laboratory reporting level (LRL) for the U.S. Geological Survey's National Water Quality Laboratory analytical schedule 1433.

[NA, not available; $\mu \mathrm{g} / \mathrm{L}$, micrograms per liter; >, greater than]

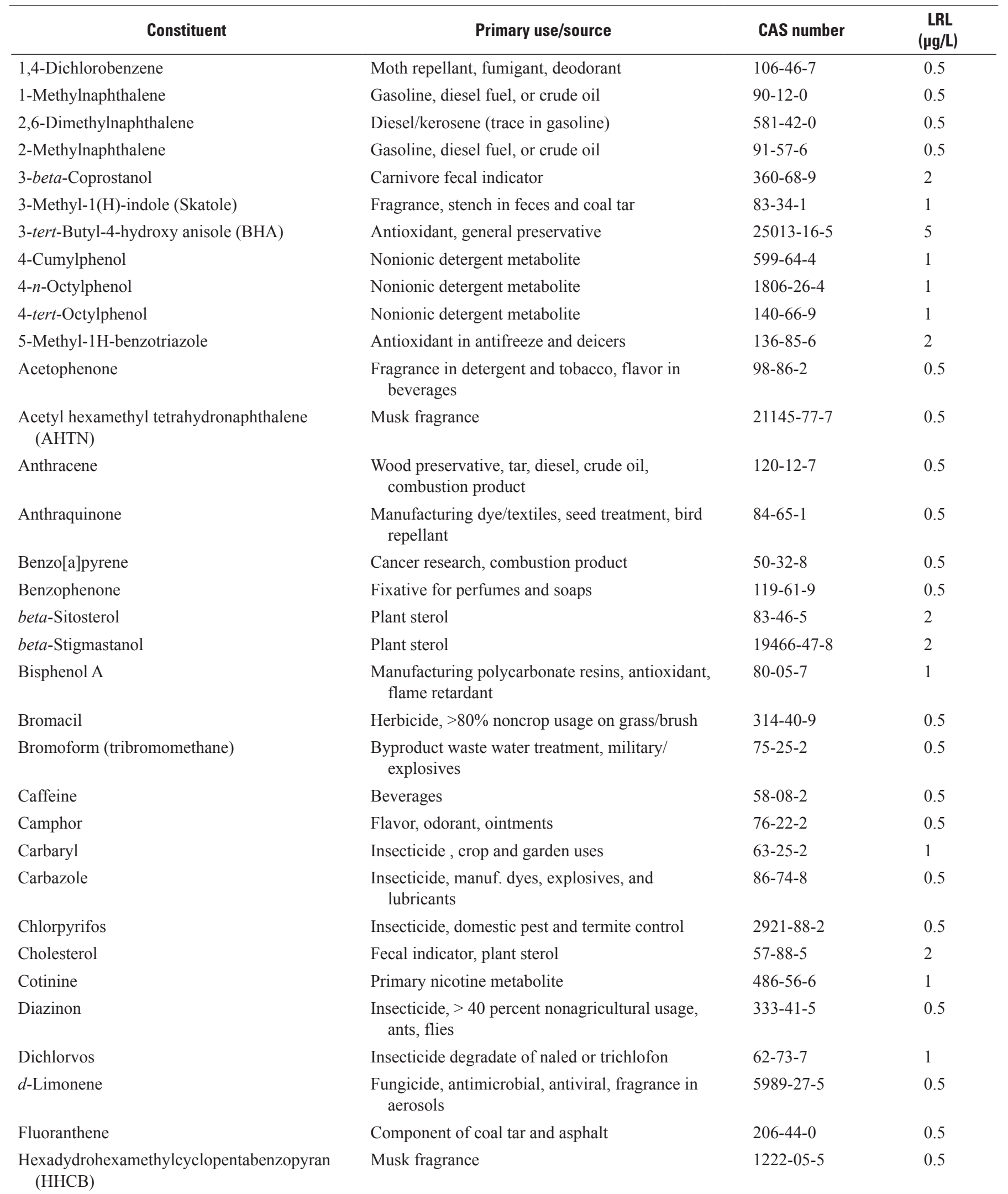


Table 2E. Waste-water indicator constituents, primary use or source, Chemical Abstract Service (CAS) number, and laboratory reporting level (LRL) for the U.S. Geological Survey's National Water Quality Laboratory analytical schedule 1433—Continued.

[NA, not available; $\mu \mathrm{g} / \mathrm{L}$, micrograms per liter; >, greater than]

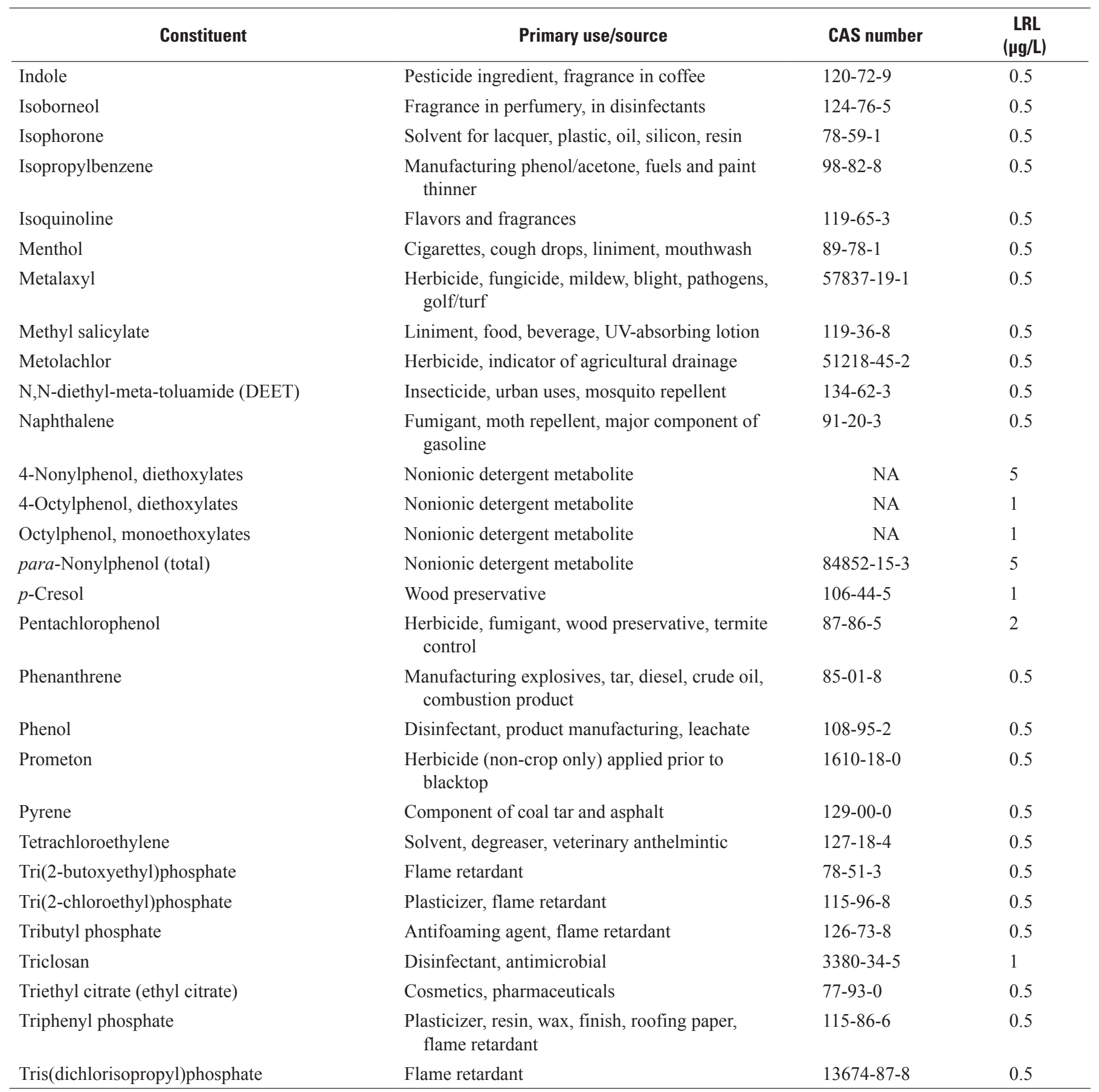


Table 2F. Constituents of special interest: perchlorate, 1,2,3-tricholoropropane, and N-nitrosodimethylamine (NDMA), Chemical Abstract Service (CAS) number, and minimum reporting level (MRL) for Montgomery Watson Harza Laboratory.

$[\mu \mathrm{g} / \mathrm{L}$, micrograms per liter]

\begin{tabular}{llll}
\hline \multicolumn{1}{c}{ Constituent } & \multicolumn{1}{c}{ Primary use/source } & CAS number & $\begin{array}{c}\text { MRL } \\
(\boldsymbol{\mu g} / \mathbf{L})\end{array}$ \\
\hline Perchlorate & Rocket fuel, fireworks, flares & $14797-73-0$ & 0.5 \\
$1,2,3$-Trichloropropane & Solvent & $25735-29-9$ & 0.005 \\
N-Nitrosodimethylamine & Rocket fuel manuf., plasticizer & $62-75-9$ & 0.002 \\
\hline
\end{tabular}

Table 2G. Nutrients and dissolved organic carbon, Chemical Abstract Service (CAS) number, and laboratory reporting level (LRL) for the U.S. Geological Survey's National Water Quality Laboratory analytical schedule 2755 and laboratory code 2613.

[NA, not available; $\mu \mathrm{g} / \mathrm{L}$, micrograms per liter]

\begin{tabular}{|c|c|c|}
\hline Constituent & CAS number & $\begin{array}{c}\text { LRL } \\
\mu \mathrm{g} / \mathrm{L})\end{array}$ \\
\hline Ammonia & $7664-41-7$ & 0.04 \\
\hline Nitrite & $14797-65-0$ & 0.008 \\
\hline Nitrate plus nitrite & NA & 0.06 \\
\hline Total nitrogen (ammonia, nitrite, nitrate, organic nitrogen) & $17778-88-0$ & 0.03 \\
\hline Phosphorus, phosphate, ortho & $14265-44-2$ & 0.006 \\
\hline
\end{tabular}


Table 2H. Major and minor ions and trace elements, Chemical Abstract Service (CAS) number, and laboratory reporting level (LRL) for the U.S. Geological Survey's National Water Quality Laboratory analytical schedule 1948.

[NA, not available; mg/L, milligrams per liter; $\mu \mathrm{g} / \mathrm{L}$, micrograms per liter]

\begin{tabular}{|c|c|c|}
\hline Constituent & CAS number & LRL \\
\hline Major and Minor lons & & $(\mu \mathrm{g} / \mathrm{L})$ \\
\hline Bromide & $24959-67-9$ & 0.02 \\
\hline Calcium & $7440-70-2$ & 0.02 \\
\hline Chloride & $16887-00-6$ & 0.2 \\
\hline Fluoride & $16984-48-8$ & 0.1 \\
\hline Iodide & $20461-54-5$ & 0.002 \\
\hline Magnesium & $7439-95-4$ & 0.008 \\
\hline Potassium & 2023695 & 0.16 \\
\hline Silica & $7631-86-9$ & 0.04 \\
\hline Sodium & $7440-23-5$ & 0.2 \\
\hline Sulfate & $14808-79-8$ & 0.18 \\
\hline Dissolved solids (residue on evaporation) & NA & 10 \\
\hline Trace Elements & & $(\mu \mathrm{g} / \mathrm{L})$ \\
\hline Aluminum & $7429-90-5$ & 1.6 \\
\hline Antimony & $7440-36-0$ & 0.2 \\
\hline Arsenic & $7440-38-2$ & 0.2 \\
\hline Barium & $7440-39-3$ & 0.2 \\
\hline Beryllium & $7440-41-7$ & 0.06 \\
\hline Boron & $7440-42-8$ & 8 \\
\hline Cadmium & $7440-43-9$ & 0.04 \\
\hline Chromium & $7440-47-3$ & 0.8 \\
\hline Cobalt & $7440-48-4$ & 0.014 \\
\hline Copper & $7440-50-8$ & 0.4 \\
\hline Iron & $7439-89-6$ & 6 \\
\hline Lead & $7439-92-1$ & 0.08 \\
\hline Lithium & $7439-93-2$ & 0.6 \\
\hline Manganese & $7439-96-5$ & 0.2 \\
\hline Mercury & $7439-97-6$ & 0.01 \\
\hline Molybdenum & 7439-98-7 & 0.4 \\
\hline Nickel & $7440-02-0$ & 0.06 \\
\hline Selenium & $7782-49-2$ & 0.4 \\
\hline Silver & $7440-22-4$ & 0.2 \\
\hline Strontium & $7440-24-6$ & 0.4 \\
\hline Thallium & $7440-28-0$ & 0.04 \\
\hline Tungsten & $7440-33-7$ & 0.5 \\
\hline Uranium & $7440-61-1$ & 0.04 \\
\hline Vanadium & $7440-62-2$ & 0.14 \\
\hline Zinc & $7440-66-6$ & 0.6 \\
\hline
\end{tabular}


Table 2I. Iron, arsenic and chromium speciation, Chemical Abstract Service (CAS) number, and method detection limit (MDL) for the U.S. Geological Survey's National Research Program Laboratory, Boulder, Colorado.

$[\mu \mathrm{g} / \mathrm{L}$, micrograms per liter]

\begin{tabular}{|c|c|c|}
\hline Constituent & CAS number & $\begin{array}{c}\text { MDL } \\
(\mu \mathrm{g} / \mathrm{L})\end{array}$ \\
\hline Iron & $7439-89-6$ & 1 \\
\hline Arsenic & $7440-38-2$ & 0.5 \\
\hline Arsenic (III) & $1327-53-3$ & 1 \\
\hline
\end{tabular}

Table 2J. Isotopic and radioactive constituents, Chemical Abstract Service (CAS) number, reporting level type, reporting level and (or) uncertainty, and reporting units for the U.S. Geological Survey's National Water Quality Laboratory, Stable Isotope and Tritium Laboratory, Menlo Park, California', Stable Isotope Laboratory, Reston, Virginia', and the contract laboratories Eberline Analytical Services $^{3}$ and the University of Arizona, Accelerator Mass Spectrometry Laboratory ${ }^{4}$.

[MU, method uncertainty; NA, not available; pCi/L, picocuries per liter; SSMDC, sample specific minimum detectable concentration]

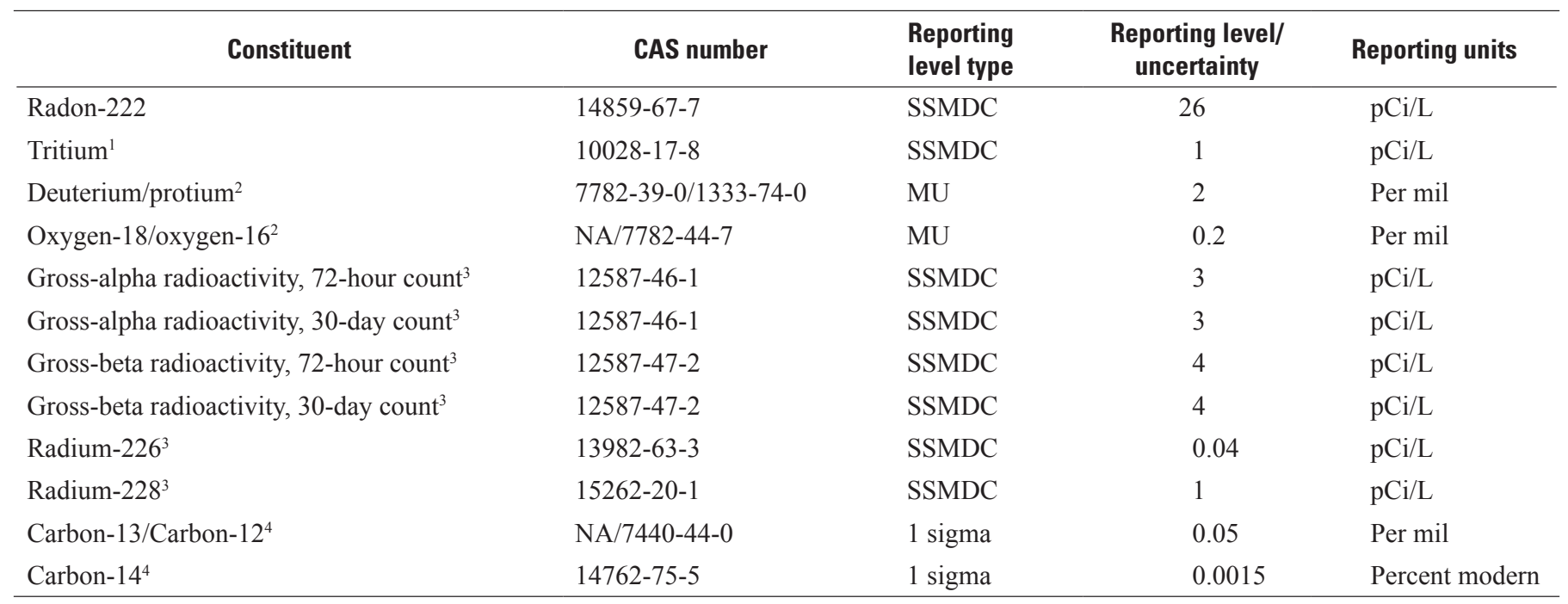


Table 2K. Tritium and dissolved gases, Chemical Abstract Service (CAS) number, method uncertainty (MU) and reporting units for Lawrence Livermore National Laboratory.

[NA, not available; $\mathrm{cm}^{3} \mathrm{STP} / \mathrm{g}$, cubic centimeter of gas at standard temperature and pressure per gram of water; $\mathrm{pCi} / \mathrm{L}$, picocuries per liter]

\begin{tabular}{|c|c|c|c|}
\hline Constituent & CAS number & $\begin{array}{c}\text { MU } \\
\text { (percent) }\end{array}$ & Unit \\
\hline Tritium & $10028-17-8$ & NA & $\mathrm{pCi} / \mathrm{L}$ \\
\hline Helium-4 & $7440-59-7$ & 2 & $\mathrm{~cm}^{3} \mathrm{STP} / \mathrm{g}$ \\
\hline Argon & $7440-37-1$ & 2 & $\mathrm{~cm}^{3} \mathrm{STP} / \mathrm{g}$ \\
\hline Xenon & $7440-63-3$ & 2 & $\mathrm{~cm}^{3} \mathrm{STP} / \mathrm{g}$ \\
\hline Methane & $74-82-8$ & 4 & $\mathrm{~cm}^{3} \mathrm{STP} / \mathrm{g}$ \\
\hline Nitrogen & $7727-37-9$ & 2 & $\mathrm{~cm}^{3} \mathrm{STP} / \mathrm{g}$ \\
\hline Oxygen & $7782-44-7$ & 2 & $\mathrm{~cm}^{3} \mathrm{STP} / \mathrm{g}$ \\
\hline
\end{tabular}

Table 2L. Microbial constiuents, primary use and source, and method detection limit (MDL) for the U.S. Geological Survey's Ohio Microbiology Laboratory parameter codes 90901, 90900, 99335 and 99332.

[NA, not available; ml, milliliters]

\begin{tabular}{lll}
\hline \multicolumn{1}{c}{ Microbial constiuent } & \multicolumn{1}{c}{ Primary use/source } & MDL \\
\hline Total coliforms & Water quality indicator/Soil, water and intestinal tracts of animals & 1 colony/100ml \\
Escherichia coliform & Sewage and animal waste indicator/ Intestinal tracts of humans and animals & 1 colony/100ml \\
F-specific coliphage & Viral indicator/Intestinal tracts of warm-blooded animals & NA \\
Somatic coliphage & Viral indicator/Fecal contaminated waters & NA \\
\hline
\end{tabular}


Table 3. Classes of chemical and microbial constituents and water-quality indicators collected for the expanded, basic-plus, basic, and hydrothermal sampling schedules for the North San Francisco Bay Ground-Water Ambient Monitoring and Assessment (GAMA) study, California, August to November 2004.

[DO, dissolved oxygen; NDMA, N-nitrosodimethylamine; SC, specific conductance]

\section{Expanded schedule}

Water-quality indicators ( $\mathrm{pH}, \mathrm{SC}, \mathrm{DO}$, temperature, alkalinity)

Volatile organic compounds

Gasoline additives and oxygenates

Pesticides

Polar pesticides and degradates

Waste-water indicator constituents

Compounds of special interest (perchlorate, NDMA, trichloropropane)

Nutrients and dissolved organic carbon

Major and minor ions and trace elements

Chromium abundance and speciation

Arsenic and iron speciation

Stable isotopes of hydrogen and oxygen

Carbon isotopes

Radium isotopes

Radon-222

Tritium $^{1}$

Tritium and noble gases ${ }^{2}$

Gross alpha/beta radiation

Microbial constituents

\section{Basic schedule}

Water-quality indicators (SC and temperature)

Volatile organic compounds

Gasoline additives and oxygenates

Pesticides

Polar pesticides and degradates

Waste-water indicator constituents

Compounds of special interest (perchlorate, NDMA, trichloropropane)

Chromium abundance and speciation

Stable isotopes of hydrogen and oxygen

Tritium ${ }^{1}$

Tritium and noble gases ${ }^{2}$

\section{Basic-plus schedule}

Water-quality indicators (SC and temperature)

Volatile organic compounds

Gasoline additives and oxygenates

Pesticides

Polar pesticides and degradates

Waste-water indicator constituents

Compounds of special interest (perchlorate, NDMA, trichloropropane)

Major and minor ions and trace elements

Chromium abundance and speciation

Arsenic and iron speciation

Stable isotopes of hydrogen and oxygen

Tritium $^{1}$

Tritium and noble gases ${ }^{2}$

${ }^{1}$ Analyzed at the U.S. Geological Survey stable isotope and tritium lab, Menlo Park, California.

${ }^{2}$ Analyzed at Lawrence Livermore National Laboratory, Livermore, California.

Water-quality indicators ( $\mathrm{pH}, \mathrm{SC}, \mathrm{DO}$, temperature, alkalinity)

Major and minor ions and trace elements

Chromium abundance and speciation

Arsenic and iron speciation

Stable isotopes of hydrogen and oxygen

Tritium $^{1}$

Tritium and noble gases ${ }^{2}$

Dissolved gases ${ }^{2}$ (nitrogen, carbon dioxide, argon, oxygen, and methane) 
Table 4. Constituents analyzed in ground-water samples collected for the North San Francisco Bay Ground-Water Ambient Monitoring and Assessment (GAMA) study, that appear on multiple analytical schedules, primary constituent classification, analytical schedules constituent appears on, and preferred analytical schedule.

[VOC, volatile organic compound]

\begin{tabular}{lllc}
\hline \multicolumn{1}{c}{ Constituent } & \multicolumn{1}{c}{ Primary classification } & Analytical schedules & Preferred' analytical schedule \\
\hline Acetone & VOC & 2020,4204 & 2020 \\
Diisopropyl ether & VOC & 2020,4204 & 2020 \\
Methyl tert-butyl ether (MTBE) & VOC & 2020,4204 & 2020 \\
Methyl tert-amyl ether & VOC & 2020,4204 & 2020 \\
tert-Butyl ethyl ether & VOC & 2020,4204 & 2020 \\
1,4-Dichlorobenzene & VOC & 1433,2020 & 2020 \\
Isopropylbenzene & VOC & 1433,2020 & 2020 \\
Naphthalene & VOC & 1433,2020 & 2020 \\
Tetrachloroethene & VOC & 1433,2020 & 2020 \\
Tribromomethane (bromoform) & VOC & 1433,2020 & 2020 \\
Caffeine & Waste-water indicator & $1433,2060,9003$ & 2060 \\
Cotinine & Waste-water indicator & 1433,9003 & 1433 \\
Atrazine & Pesticide & 2003,2060 & 2003 \\
Bromacil & Pesticide & 1433,2060 & 2060 \\
Carbaryl & Pesticide & $1433,2003,2060$ & 2003 \\
Chlorpyrifos & Pesticide & 1433,2003 & 2003 \\
Deethyl atrazine & Pesticide degradate & 2003,2060 & 2003 \\
Diazinon & Pesticide & 1433,2003 & 2003 \\
Dichlorvos & Pesticide & 1433,2003 & 2003 \\
Metalaxyl & Pesticide & $1433,2003,2060$ & 2060 \\
Metolachlor & Pesticide & 1433,2003 & 2003 \\
Prometon & Pesticide & 1433,2003 & 2003 \\
\hline
\end{tabular}

${ }^{1}$ Preferred analytical schedules are the most accurate and precise methods of analysis for the constituent shown. 
Table 5. Quality-control summary for volatile organic compounds and gasoline additives and (or) oxygenates, pesticides and (or) pesticide degradates, waste-water indicators, major and minor ions, trace elements, and nutrients and dissolved organic carbon, detected in equipment blanks, field blanks and ground-water samples collected for the North San Francisco Bay Ground-Water Ambient Monitoring and Assessment (GAMA) study, California, August to November 2004.

[Censored data are reported but not used in summary statistics; E, estimated value; $\mu \mathrm{g} / \mathrm{L}$, micrograms per liter; —, not detected]

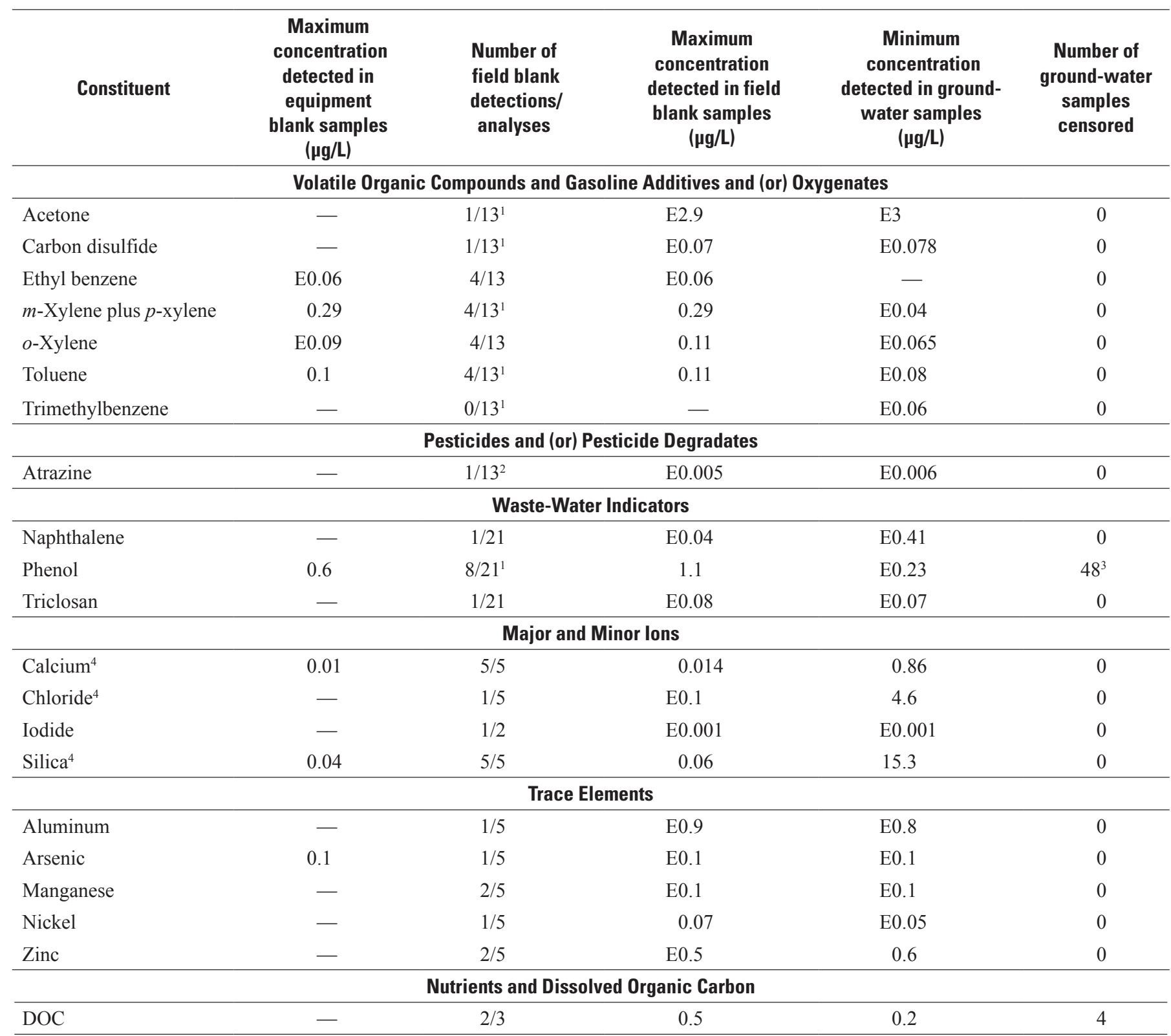

${ }^{1}$ Constituents also detected in associated source solution blanks.

${ }^{2}$ Waste-water indicators detected in one of two associated source solution blanks.

${ }^{3}$ Due to ongoing problems with the analytical procedures used to determine phenol, all ground-water samples with phenol were censored.

${ }^{4}$ Concentration in milligrams per liter. 
Table 6A. Quality-control summary of replicate volatile organic compound (VOC) and gasoline additives and (or) oxygenates, pesticides and (or) pesticide degradates, waste-water indicators, and samples for constituents of special interest with relative standard deviations greater than zero, collected for the North San Francisco Bay Ground-Water Ambient Monitoring and Assessment (GAMA) study, California, August to November 2004.

[NA, not available]

\begin{tabular}{|c|c|c|c|}
\hline Constituent $^{1}$ & $\begin{array}{l}\text { Number of relative standard } \\
\text { deviations greater than } \\
20 \text { percent/replicate pairs }\end{array}$ & $\begin{array}{l}\text { Maximum relative standard } \\
\text { deviation } \\
\text { (percent) }\end{array}$ & $\begin{array}{l}\text { Median of relative standard } \\
\text { deviations greater than zero } \\
\text { (percent) }\end{array}$ \\
\hline $\begin{array}{l}\text { All additional VOCs from } \\
\text { Schedule } 2020 \text { and } 4204\end{array}$ & $0 / 8$ & 0 & NA \\
\hline \multicolumn{4}{|c|}{ Pesticides and (or) Pesticide Degradates (Schedules 2003 and 2060) } \\
\hline $\begin{array}{l}\text { All additional pesticides from } \\
\text { Schedule } 2003\end{array}$ & $0 / 9$ & 0 & NA \\
\hline $\begin{array}{l}\text { All additional pesticides from } \\
\text { Schedule } 2060\end{array}$ & $0 / 4$ & 0 & NA \\
\hline \multicolumn{4}{|c|}{ Waste-Water Indicators (Schedule 1433) } \\
\hline \multicolumn{4}{|c|}{ Constituents of Special Interest } \\
\hline Perchlorate $^{2}$ & $0 / 6$ & 0 & NA \\
\hline $1,2,3$ - Trichloropropane ${ }^{2}$ & $0 / 6$ & 0 & NA \\
\hline N-Nitrosodimethylamine ${ }^{2}$ & $0 / 6$ & 0 & NA \\
\hline
\end{tabular}

${ }^{1}$ Due to the large number of constituents, only constituents with relative standard deviations above zero are shown.

${ }^{2}$ Samples analyzed at Montgomery Watson Laboratories, California. 
Table 6B. Quality-control summary of replicate nutrient and dissolved organic carbon samples collected for the North San Francisco Bay Ground-Water Ambient Monitoring and Assessment (GAMA) study, California, August to November 2004.

[NA, not available]

\begin{tabular}{lccc}
\hline \multicolumn{1}{c}{ Constituent } & $\begin{array}{c}\text { Number of relative standard } \\
\text { deviations greater than } \\
\mathbf{2 0} \text { percent/replicate pairs }\end{array}$ & $\begin{array}{c}\text { Maximum relative standard } \\
\text { deviation } \\
\text { (percent) }\end{array}$ & $\begin{array}{c}\text { Median of relative standard } \\
\text { deviations greater than zero } \\
\text { (percent) }\end{array}$ \\
\hline Dissolved organic carbon & $0 / 3$ & 0 & NA \\
Phosphorus & $0 / 3$ & 0.4 & 0 \\
Total nitrogen & $0 / 3$ & 1.2 & 0 \\
Nitrate plus nitrite & $0 / 3$ & 1.1 & 0 \\
Ammonia & $0 / 3$ & 0 & NA \\
Nitrite & $0 / 3$ & 0 & NA \\
\hline
\end{tabular}

Table 6C. Quality-control summary of replicate major and minor ion samples collected for the North San Francisco Bay Ground-Water Ambient Monitoring and Assessment (GAMA) study, California, August to November 2004.

[NA, not available]

\begin{tabular}{lccc}
\hline Constituent & $\begin{array}{c}\text { Number of relative standard } \\
\text { deviations greater than } \\
\text { 20 percent/replicate pairs }\end{array}$ & $\begin{array}{c}\text { Maximum relative standard } \\
\text { deviation } \\
\text { (percent) }\end{array}$ & $\begin{array}{c}\text { Median of relative standard } \\
\text { deviations greater than zero } \\
\text { (percent) }\end{array}$ \\
\hline Bromide & $1 / 4$ & 84.9 & 25.3 \\
Calcium & $0 / 4$ & 4.0 & 1.6 \\
Chloride & $0 / 4$ & 1.6 & 0.4 \\
Fluorine & $0 / 4$ & 8.8 & 4.0 \\
Iodide & $0 / 3$ & 0.0 & NA \\
Magnesium & $0 / 4$ & 3.0 & 1.5 \\
Potassium & $0 / 4$ & 3.2 & 2.2 \\
Silica & $0 / 4$ & 4.4 & 1.9 \\
Sodium & $0 / 4$ & 2.1 & 1.0 \\
Sulfate & $0 / 4$ & 16.2 & 4.1 \\
\hline
\end{tabular}


Table 6D. Quality-control summary of replicate trace-element samples collected for the North San Francisco Bay Ground-Water Ambient Monitoring and Assessment (GAMA) study, California, August to November 2004.

[NA, not available]

\begin{tabular}{|c|c|c|c|}
\hline Constituent & $\begin{array}{l}\text { Number of relative standard } \\
\text { deviations greater than } \\
20 \text { percent/replicate pairs }\end{array}$ & $\begin{array}{l}\text { Maximum relative } \\
\text { standard deviation } \\
\text { (percent) }\end{array}$ & $\begin{array}{l}\text { Median of relative standard } \\
\text { deviations greater than zero } \\
\text { (percent) }\end{array}$ \\
\hline Aluminum & $0 / 3$ & 0 & NA \\
\hline Antimony & $0 / 3$ & 0 & NA \\
\hline Arsenic $^{1}$ & $0 / 3$ & 8.4 & 4.2 \\
\hline Arsenic $^{2}$ & $0 / 4$ & 7.7 & 1.9 \\
\hline Arsenic $(\mathrm{III})^{2}$ & $0 / 4$ & 6.7 & 1.9 \\
\hline Barium & $0 / 3$ & 0.9 & 0.6 \\
\hline Beryllium & $0 / 3$ & 0 & NA \\
\hline Boron & $0 / 3$ & 5.2 & 1.1 \\
\hline Cadmium & $0 / 3$ & 0 & NA \\
\hline Chromium $^{1}$ & $0 / 3$ & 7.4 & 0 \\
\hline Chromium $^{2}$ & $5 / 11$ & 53 & 27 \\
\hline Chromium (VI) ${ }^{2}$ & $6 / 13$ & 96 & 31 \\
\hline Cobalt & $0 / 3$ & 4.3 & 3.8 \\
\hline Copper & $0 / 3$ & 20 & 19 \\
\hline Iron $^{1}$ & $0 / 4$ & 6.6 & 3.1 \\
\hline Iron $^{2}$ & $1 / 4$ & 57 & 15 \\
\hline Iron (II) $)^{2}$ & $1 / 4$ & 61 & 17 \\
\hline Lead & $0 / 3$ & 18 & 4.2 \\
\hline Lithium & $0 / 3$ & 2.2 & 1.2 \\
\hline Manganese & $0 / 3$ & 1.7 & 0.6 \\
\hline Mercury & $0 / 3$ & 0 & NA \\
\hline Molybdenum & $0 / 3$ & 13 & 0 \\
\hline Nickel & $0 / 3$ & 4.2 & 3.6 \\
\hline Selenium & $0 / 3$ & 0 & NA \\
\hline Silver & $0 / 3$ & 0 & NA \\
\hline Strontium & $0 / 3$ & 0.7 & 0.6 \\
\hline Thallium & $0 / 0$ & 0 & NA \\
\hline Tungsten & $0 / 4$ & 0 & NA \\
\hline Uranium & $0 / 3$ & 13 & 0 \\
\hline Vanadium & $1 / 3$ & 46 & 2.4 \\
\hline Zinc & $0 / 3$ & 17 & 1.4 \\
\hline
\end{tabular}

${ }^{1}$ Samples analyzed at U.S. Geological Survey national water-quality laboratory, Denver, Colorado.

${ }^{2}$ Samples analyzed at U.S. Geological Survey national research program laboratory, Boulder, Colorado. 
Table 6E. Quality-control summary of replicate isotope and radioactivity samples collected for the North San Francisco Bay GroundWater Ambient Monitoring and Assessment (GAMA) study, California, August to November 2004.

[NA, not available]

\begin{tabular}{|c|c|c|c|}
\hline Constituent & $\begin{array}{l}\text { Number of relative standard } \\
\text { deviations greater than } \\
20 \text { percent/replicate pairs }\end{array}$ & $\begin{array}{l}\text { Maximum relative } \\
\text { standard deviation } \\
\text { (percent) }\end{array}$ & $\begin{array}{l}\text { Median of relative standard } \\
\text { deviations greater than zero } \\
\text { (percent) }\end{array}$ \\
\hline Alpha radioactivity, 30 day count & $3 / 3$ & 138 & 57 \\
\hline Alpha radioactivity, 72 hour count & $3 / 3$ & 36 & 31 \\
\hline Beta radioactivity, 30 day count & $2 / 3$ & 39 & 33 \\
\hline Beta radioactivity, 72 hour count & $1 / 3$ & 25 & 13 \\
\hline Radium-226 & $1 / 3$ & 48 & 20 \\
\hline Radium-228 & $3 / 3$ & 110 & 54 \\
\hline Deuterium/Protium & $0 / 10$ & 3.2 & 0.6 \\
\hline Tritium $^{1}$ & $4 / 11$ & 137 & 31 \\
\hline Oxygen-18/Oxygen-16 & $0 / 10$ & 1.4 & 0.5 \\
\hline $\mathrm{He}^{1}$ & $0 / 10$ & 6.6 & 0.5 \\
\hline $\mathrm{Ne}^{1}$ & $0 / 10$ & 5.9 & 1.7 \\
\hline $\operatorname{Ar}^{1}$ & $0 / 10$ & 11 & 0.4 \\
\hline $\mathrm{Kr}^{1}$ & $0 / 10$ & 3.6 & 1.6 \\
\hline $\mathrm{Xe}^{1}$ & $0 / 10$ & 2.2 & 0.6 \\
\hline
\end{tabular}

\footnotetext{
${ }^{2}$ Analysis done at U.S. Geological Survey, Menlo Park, California.
} 
Table 7A. Quality-control summary of volatile organic compounds (VOCs), gasoline additives and oxygenates, NDMA and 1,2,3trichloropropane matrix spike recoveries in samples collected for the North San Francisco Bay Ground-Water Ambient Monitoring and Assessment (GAMA) study, California, August to November 2004.

[Bold values indicate recovery values outside acceptable range, 70 to 130 percent]

\begin{tabular}{|c|c|c|c|c|}
\hline Constituent & $\begin{array}{l}\text { Number of } \\
\text { spike } \\
\text { samples }\end{array}$ & $\begin{array}{l}\text { Minimum } \\
\text { recovey } \\
\text { (percent) }\end{array}$ & $\begin{array}{c}\text { Maximum } \\
\text { recovey } \\
\text { (percent) }\end{array}$ & $\begin{array}{l}\text { Median } \\
\text { recovey } \\
\text { (percent) }\end{array}$ \\
\hline 1,1,1,2-Tetrachloroethane & 9 & 94 & 120 & 111 \\
\hline 1,1,1-Trichloroethane $(\mathrm{TCA})^{1}$ & 9 & 104 & 135 & 128 \\
\hline 1,1,2,2-Tetrachloroethane & 9 & 98 & 123 & 110 \\
\hline 1,1,2-Trichloroethane & 9 & 106 & 136 & 114 \\
\hline 1,1-Dichloroethane ${ }^{1}$ & 9 & 104 & 127 & 118 \\
\hline 1,1-Dichloroethylene (DCE) & 9 & 102 & 130 & 111 \\
\hline 1,1-Dichloropropene & 9 & 109 & 132 & 118 \\
\hline 1,2,3,4-Tetramethylbenzene & 9 & 87 & 115 & 104 \\
\hline 1,2,3-Trimethylbenzene ${ }^{1}$ & 9 & 87 & 113 & 103 \\
\hline 1,2,4-Trichlorobenzene & 9 & 82 & 112 & 96 \\
\hline 1,2,4-Trimethylbenzene & 9 & 93 & 117 & 108 \\
\hline 1,2-Dibromo-3-chloropropane (DBCP) & 9 & 95 & 111 & 106 \\
\hline 1,2-Dibromoethane & 9 & 95 & 123 & 110 \\
\hline 1,2-Dichlorobenzene & 9 & 95 & 111 & 105 \\
\hline 1,2-Dichloroethane & 9 & 107 & 137 & 126 \\
\hline 1,2-Dichloropropane & 9 & 93 & 120 & 105 \\
\hline 1,3,5-Trimethylbenzene & 9 & 82 & 112 & 101 \\
\hline 2-Hexanone & 9 & 101 & 127 & 115 \\
\hline 3-Chloropropene & 9 & 102 & 125 & 114 \\
\hline 4-Chlorotoluene & 9 & 89 & 113 & 101 \\
\hline 4-Isopropyl-1-methylbenzene & 9 & 89 & 110 & 101 \\
\hline 4-Methyl-2-pentanone & 9 & 94 & 118 & 110 \\
\hline Acetone $^{1,3}$ & 9 & 111 & 149 & 126 \\
\hline Acrylonitrile & 9 & 100 & 122 & 113 \\
\hline Benzene & 9 & 100 & 120 & 111 \\
\hline Bromobenzene & 9 & 90 & 108 & 101 \\
\hline Bromochloromethane $^{1}$ & 9 & 99 & 119 & 109 \\
\hline Bromodichloromethane & 9 & 111 & 136 & 121 \\
\hline Bromoethene & 9 & 102 & 131 & 113 \\
\hline Bromoform (tribromomethane) ${ }^{1}$ & 9 & 101 & 132 & 115 \\
\hline
\end{tabular}


Table 7A. Quality-control summary of volatile organic compounds (VOCs), gasoline additives and oxygenates, NDMA and 1,2,3trichloropropane matrix spike recoveries in samples collected for the North San Francisco Bay Ground-Water Ambient Monitoring and Assessment (GAMA) study, California, August to November 2004-Continued.

[Bold values indicate recovery values outside acceptable range, 70 to 130 percent]

\begin{tabular}{|c|c|c|c|c|}
\hline Constituent & $\begin{array}{l}\text { Number of } \\
\text { spike } \\
\text { samples }\end{array}$ & $\begin{array}{l}\text { Minimum } \\
\text { recovey } \\
\text { (percent) }\end{array}$ & $\begin{array}{c}\text { Maximum } \\
\text { recovey } \\
\text { (percent) }\end{array}$ & $\begin{array}{l}\text { Median } \\
\text { recovey } \\
\text { (percent) }\end{array}$ \\
\hline Bromomethane & 9 & 88 & 148 & 123 \\
\hline Butylbenzene & 9 & 76 & 103 & 91 \\
\hline Carbon disulfide ${ }^{1}$ & 9 & 80 & 153 & 96 \\
\hline Chlorobenzene & 9 & 94 & 114 & 106 \\
\hline Chloroform (trichloromethane) ${ }^{1}$ & 9 & 102 & 119 & 113 \\
\hline Chloromethane & 9 & 91 & 128 & 105 \\
\hline cis-1,2-Dichloroethylene $^{1}$ & 9 & 95 & 119 & 108 \\
\hline cis-1,3-Dichloropropene & 9 & 89 & 109 & 98 \\
\hline Dichloromethane (methylene chloride) & 9 & 95 & 116 & 109 \\
\hline Diethyl ether & 9 & 94 & 128 & 113 \\
\hline Diisopropyl ether ${ }^{1}$ & 9 & 98 & 115 & 111 \\
\hline Ethyl methacrylate & 9 & 95 & 114 & 102 \\
\hline Ethyl tert-butyl ether (ETBE) $)^{1}$ & 9 & 111 & 135 & 123 \\
\hline Ethylbenzene & 9 & 96 & 115 & 106 \\
\hline Hexachlorobutadiene & 9 & 92 & 116 & 98 \\
\hline Hexachloroethane & 9 & 98 & 117 & 112 \\
\hline Isopropylbenzene & 9 & 100 & 119 & 108 \\
\hline Methyl tert-butyl ether (MTBE) $)^{1,3}$ & 9 & 97 & 127 & 113 \\
\hline Naphthalene & 9 & 75 & 106 & 98 \\
\hline Nitrosodimethylamine ${ }^{2}$ (NDMA) & 10 & 56 & 90 & 73 \\
\hline$n$-Propylbenzene & 9 & 87 & 113 & 102 \\
\hline$o$-Ethyl toluene & 9 & 91 & 109 & 100 \\
\hline$o$-Xylene ${ }^{1}$ & 9 & 94 & 114 & 104 \\
\hline sec-Butylbenzene & 9 & 98 & 114 & 104 \\
\hline Styrene & 9 & 87 & 111 & 107 \\
\hline tert-Amyl methyl ether ${ }^{1}$ & 9 & 96 & 123 & 111 \\
\hline tert-Amyl alcohol & 9 & 93 & 111 & 101 \\
\hline tert-Butyl alcohol & 9 & 93 & 117 & 105 \\
\hline tert-Butyl ethyl ether ${ }^{1}$ & 9 & 104 & 128 & 116 \\
\hline tert-Butylbenzene & 9 & 104 & 127 & 115 \\
\hline
\end{tabular}


Table 7A. Quality-control summary of volatile organic compounds (VOCs), gasoline additives and oxygenates, NDMA and 1,2,3trichloropropane matrix spike recoveries in samples collected for the North San Francisco Bay Ground-Water Ambient Monitoring and Assessment (GAMA) study, California, August to November 2004—Continued.

[Bold values indicate recovery values outside acceptable range, 70 to 130 percent]

\begin{tabular}{|c|c|c|c|c|}
\hline Constituent & $\begin{array}{c}\text { Number of } \\
\text { spike } \\
\text { samples }\end{array}$ & $\begin{array}{l}\text { Minimum } \\
\text { recovey } \\
\text { (percent) }\end{array}$ & $\begin{array}{c}\text { Maximum } \\
\text { recovey } \\
\text { (percent) }\end{array}$ & $\begin{array}{l}\text { Median } \\
\text { recovey } \\
\text { (percent) }\end{array}$ \\
\hline 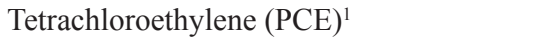 & 9 & 97 & 121 & 106 \\
\hline Tetrachloromethane (carbon tetrachloride) ${ }^{1}$ & 9 & 100 & 138 & 134 \\
\hline Tetrahydrofuran ${ }^{1}$ & 9 & 96 & 125 & 118 \\
\hline Toluene $^{1}$ & 9 & 96 & 115 & 106 \\
\hline trans-1,3-Dichloropropene & 9 & 94 & 116 & 111 \\
\hline trans-1,4-Dichloro-2-butene & 9 & 114 & 155 & 141 \\
\hline Trichloroethylene $(\mathrm{TCE})^{1}$ & 9 & 99 & 121 & 112 \\
\hline Trichlorofluoromethane (CFC-11) & 9 & 107 & 148 & 134 \\
\hline
\end{tabular}

${ }^{2}$ Constituent analyzed by Montgomery Watson on the constituents of special interest schedule.

${ }^{3}$ Constituent on schedules 2020 and 4024; only 2020 values are reported because it is the preferred analytical schedule. 
Table 7B. Quality-control summary of matrix pesticide spike recoveries in samples collected for the North San Francisco Bay GroundWater Ambient Monitoring and Assessment (GAMA) study, California, August to November 2004.

[Bold values indicate spike recoveries outside the acceptable range, 70 to 130 percent; NA, not available]

\begin{tabular}{|c|c|c|c|c|c|}
\hline Constituent & $\begin{array}{l}\text { Number } \\
\text { of spike } \\
\text { samples }\end{array}$ & $\begin{array}{l}\text { Minimum } \\
\text { recovery } \\
\text { (percent) }\end{array}$ & $\begin{array}{c}\text { Maximum } \\
\text { recovery } \\
\text { (percent) }\end{array}$ & $\begin{array}{l}\text { Median } \\
\text { recovery } \\
\text { (percent) }\end{array}$ & $\begin{array}{c}\text { Single } \\
\text { value } \\
\text { (percent) }\end{array}$ \\
\hline 1-Naphthol & 5 & 8 & 24 & 16 & NA \\
\hline 2,6-Diethylaniline & 5 & 80 & 115 & 98 & NA \\
\hline 2-Chloro-2',6'-diethylacetanilide & 5 & 80 & 130 & 91 & NA \\
\hline 2-Chloro-4-isopropylamino-6-amino-s-triazine (deethyl atrazine) ${ }^{1}$ & 5 & 36 & 70 & 43 & NA \\
\hline 3,4-Dichloroaniline & 5 & 43 & 92 & 81 & NA \\
\hline 4-Chloro-2-methylphenol & 5 & 53 & 100 & 69 & NA \\
\hline Acetochlor & 5 & 70 & 125 & 91 & NA \\
\hline Alachlor & 5 & 77 & 127 & 97 & NA \\
\hline Benfluralin, water & 5 & 54 & 68 & 57 & NA \\
\hline Carbaryl & 5 & 77 & 112 & 98 & NA \\
\hline Chlorpyrifos & 5 & 76 & 122 & 86 & NA \\
\hline Chlorpyrifos oxygen analog & 5 & 15 & 52 & 50 & NA \\
\hline cis-Permethrin & 5 & 33 & 80 & 46 & NA \\
\hline Cyfluthrin & 5 & 29 & 116 & 42 & NA \\
\hline Cypermethrin & 5 & 27 & 93 & 35 & NA \\
\hline dacthal (DCPA) & 5 & 97 & 143 & 118 & NA \\
\hline Desulfinyl fipronil & 5 & 79 & 129 & 94 & NA \\
\hline Dimethoate & 5 & 17 & 27 & 27 & NA \\
\hline Ethion & 5 & 44 & 107 & 62 & NA \\
\hline Ethion monoxon & 5 & 72 & 139 & 77 & NA \\
\hline Fenamiphos & 5 & 31 & 131 & 63 & NA \\
\hline Fenamiphos sulfone & 5 & 40 & 148 & 62 & NA \\
\hline Fenamiphos sulfoxide & 5 & 19 & 94 & 56 & NA \\
\hline Fipronil & 5 & 67 & 82 & 81 & NA \\
\hline Fipronil sulfide & 5 & 69 & 111 & 85 & NA \\
\hline Fipronil sulfone & 5 & 52 & 118 & 77 & NA \\
\hline Fonofos & 5 & 72 & 105 & 97 & NA \\
\hline Fonofos oxygen analog & 5 & 57 & 83 & 58 & NA \\
\hline Hexazinone & 5 & 44 & 111 & 61 & NA \\
\hline Iprodione & 5 & 52 & 100 & 83 & NA \\
\hline
\end{tabular}


Table 7B. Quality-control summary of matrix pesticide spike recoveries in samples collected for the North San Francisco Bay GroundWater Ambient Monitoring and Assessment (GAMA) study, California, August to November 2004—Continued.

[Bold values indicate spike recoveries outside the acceptable range, 70 to 130 percent; NA, not available]

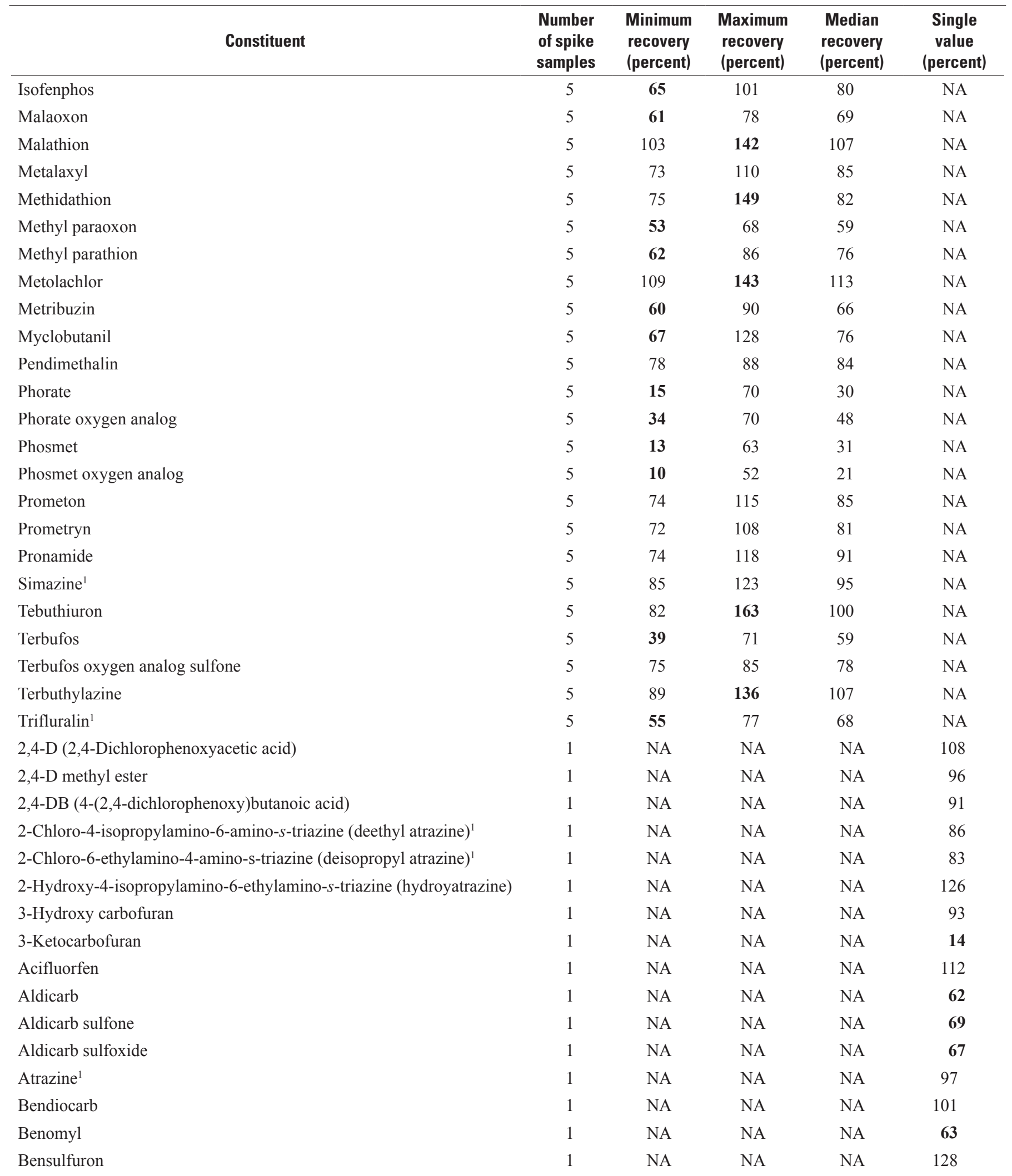


Table 7B. Quality-control summary of matrix pesticide spike recoveries in samples collected for the North San Francisco Bay GroundWater Ambient Monitoring and Assessment (GAMA) study, California, August to November 2004—Continued.

[Bold values indicate spike recoveries outside the acceptable range, 70 to 130 percent; NA, not available]

\begin{tabular}{|c|c|c|c|c|c|}
\hline Constituent & $\begin{array}{l}\text { Number } \\
\text { of spike } \\
\text { samples }\end{array}$ & $\begin{array}{l}\text { Minimum } \\
\text { recovery } \\
\text { (percent) }\end{array}$ & $\begin{array}{c}\text { Maximum } \\
\text { recovery } \\
\text { (percent) }\end{array}$ & $\begin{array}{l}\text { Median } \\
\text { recovery } \\
\text { (percent) }\end{array}$ & $\begin{array}{c}\text { Single } \\
\text { value } \\
\text { (percent) }\end{array}$ \\
\hline Bentazon & 1 & NA & NA & NA & 70 \\
\hline Bromacil & 1 & NA & NA & NA & 87 \\
\hline Bromoxynil & 1 & NA & NA & NA & 71 \\
\hline Caffeine & 1 & NA & NA & NA & 84 \\
\hline Carbofuran & 1 & NA & NA & NA & 95 \\
\hline Chloramben methyl ester & 1 & NA & NA & NA & 83 \\
\hline Chlorimuron & 1 & NA & NA & NA & 160 \\
\hline Chlorodiamino-s-triazine & 1 & NA & NA & NA & 121 \\
\hline Dacthal monoacid & 1 & NA & NA & NA & 102 \\
\hline Dicamba & 1 & NA & NA & NA & 87 \\
\hline Dichlorprop & 1 & NA & NA & NA & 95 \\
\hline Dinoseb & 1 & NA & NA & NA & 107 \\
\hline Diphenamid $^{1}$ & 1 & NA & NA & NA & 96 \\
\hline Diuron & 1 & NA & NA & NA & 101 \\
\hline Fenuron & 1 & NA & NA & NA & 93 \\
\hline Flumetsulam & 1 & NA & NA & NA & 137 \\
\hline Fluometuron & 1 & NA & NA & NA & 97 \\
\hline Metalaxyl & 1 & NA & NA & NA & 95 \\
\hline Methiocarb & 1 & NA & NA & NA & 98 \\
\hline Methomyl & 1 & NA & NA & NA & 58 \\
\hline Metsulfuron & 1 & NA & NA & NA & 94 \\
\hline N-(4-Chlorophenyl)-N'-methylurea & 1 & NA & NA & NA & 66 \\
\hline Neburon & 1 & NA & NA & NA & 97 \\
\hline Nicosulfuron & 1 & NA & NA & NA & 101 \\
\hline Norflurazon & 1 & NA & NA & NA & 99 \\
\hline Oryzalin & 1 & NA & NA & NA & 79 \\
\hline Oxamyl & 1 & NA & NA & NA & 92 \\
\hline Picloram & 1 & NA & NA & NA & 79 \\
\hline Propham & 1 & NA & NA & NA & 99 \\
\hline
\end{tabular}


Table 7B. Quality-control summary of matrix pesticide spike recoveries in samples collected for the North San Francisco Bay GroundWater Ambient Monitoring and Assessment (GAMA) study, California, August to November 2004—Continued.

[Bold values indicate spike recoveries outside the acceptable range, 70 to 130 percent; NA, not available]

\begin{tabular}{|c|c|c|c|c|c|}
\hline Constituent & $\begin{array}{l}\text { Number } \\
\text { of spike } \\
\text { samples }\end{array}$ & $\begin{array}{l}\text { Minimum } \\
\text { recovery } \\
\text { (percent) }\end{array}$ & $\begin{array}{l}\text { Maximum } \\
\text { recovery } \\
\text { (percent) }\end{array}$ & $\begin{array}{l}\text { Median } \\
\text { recovery } \\
\text { (percent) }\end{array}$ & $\begin{array}{c}\text { Single } \\
\text { value } \\
\text { (percent) }\end{array}$ \\
\hline Propiconazole & 1 & NA & NA & NA & 86 \\
\hline Propoxur & 1 & NA & NA & NA & 93 \\
\hline Siduron & 1 & NA & NA & NA & 105 \\
\hline Sulfometuron ${ }^{1}$ & 1 & NA & NA & NA & 120 \\
\hline Terbacil & 1 & NA & NA & NA & 91 \\
\hline Tribenuron methyl & 1 & NA & NA & NA & $\mathbf{0}$ \\
\hline Triclopyr & 1 & NA & NA & NA & 103 \\
\hline
\end{tabular}


Table 7C. Quality-control summary of matrix waste-water indicators spike recoveries in samples collected for the North San Francisco Bay Ground-Water Ambient Monitoring and Assessment (GAMA) study, California, August to November 2004.

[Bold values indicate spike recoveries outside the acceptable range, 70 to 130 percent]

\begin{tabular}{|c|c|c|c|c|}
\hline Constituent & $\begin{array}{l}\text { Number of } \\
\text { spike } \\
\text { samples }\end{array}$ & $\begin{array}{l}\text { Minimum } \\
\text { recovery } \\
\text { (percent) }\end{array}$ & $\begin{array}{l}\text { Maximum } \\
\text { recovery } \\
\text { (percent) }\end{array}$ & $\begin{array}{l}\text { Median } \\
\text { recovey } \\
\text { (percent) }\end{array}$ \\
\hline 1,4-Dichlorobenzene & 4 & 43 & 70 & 57 \\
\hline 1-Methylnaphthalene & 4 & 61 & 90 & 80 \\
\hline 2,6-Dimethylnaphthalene & 4 & 57 & 93 & 85 \\
\hline 2-Methylnaphthalene & 4 & 57 & 98 & 84 \\
\hline 3-Methyl-1H-indole (skatol) & 4 & 54 & 120 & 96 \\
\hline 3-tert-Butyl-4-hydroxyanisole (BHA) & 4 & 11 & 33 & 21 \\
\hline 4-Cumylphenol, water & 4 & 48 & 98 & 85 \\
\hline 4-Nonylphenol & 4 & 41 & 101 & 58 \\
\hline 9,10-Anthraquinone & 4 & 38 & 97 & 79 \\
\hline Acetophenone & 4 & 63 & 112 & 110 \\
\hline Acetyl hexamethyl tetrahydro naphthalene (tonalide) & 4 & 61 & 122 & 96 \\
\hline Anthracene, water & 4 & 70 & 111 & 98 \\
\hline Benzo[a]pyrene & 4 & 52 & 91 & 72 \\
\hline Benzophenone & 4 & 57 & 120 & 104 \\
\hline beta-Sitosterol & 4 & $\mathbf{0}$ & 73 & 49 \\
\hline beta-Stigmastanol & 4 & $\mathbf{0}$ & 65 & 51 \\
\hline Bisphenol $\mathrm{A}^{1}$ & 4 & 32 & 102 & 77 \\
\hline Cholesterol & 4 & 42 & 78 & 59 \\
\hline Cotinine & 4 & 55 & 108 & 83 \\
\hline DEET & 4 & 59 & 120 & 103 \\
\hline Diazinon $^{1}$ & 4 & 70 & 133 & 103 \\
\hline Dichlorvos & 3 & $\mathbf{0}$ & 3 & 2 \\
\hline Diethoxynonylphenol NPEO2 total) & 4 & 38 & 114 & 107 \\
\hline Diethoxyoctylphenol (OPEO2) & 4 & 32 & 174 & 44 \\
\hline$d$-Limonene $^{1}$ & 4 & 16 & 55 & 36 \\
\hline Ethoxyoctylphenol (OPEO1) ${ }^{1}$ & 4 & 27 & 106 & 40 \\
\hline Fluoranthene & 4 & 77 & 120 & 102 \\
\hline Hexahydrohexamethyl cyclopentabenzopyran (galaxolide) & 4 & 55 & 122 & 81 \\
\hline Indole, water ${ }^{1}$ & 4 & 57 & 92 & 79 \\
\hline Isoborneol, water & 4 & 64 & 102 & 92 \\
\hline Isophorone $^{1}$ & 4 & 70 & 107 & 101 \\
\hline
\end{tabular}


Table 7C. Quality-control summary of matrix waste-water indicators spike recoveries in samples collected for the North San Francisco Bay Ground-Water Ambient Monitoring and Assessment (GAMA) study, California, August to November 2004—Continued.

[Bold values indicate spike recoveries outside the acceptable range, 70 to 130 percent]

\begin{tabular}{|c|c|c|c|c|}
\hline Constituent & $\begin{array}{l}\text { Number of } \\
\text { spike } \\
\text { samples }\end{array}$ & $\begin{array}{r}\text { Minimum } \\
\text { recovery } \\
\text { (percent) }\end{array}$ & $\begin{array}{l}\text { Maximum } \\
\text { recovery } \\
\text { (percent) }\end{array}$ & $\begin{array}{l}\text { Median } \\
\text { recovey } \\
\text { (percent) }\end{array}$ \\
\hline Isopropylbenzene (Cumene) & 4 & 25 & 56 & 38 \\
\hline Isoquinoline & 4 & 46 & 97 & 86 \\
\hline Menthol $^{1}$ & 4 & 50 & 104 & 79 \\
\hline Metalaxyl & 4 & 68 & 133 & 111 \\
\hline Methyl salicylate & 4 & 57 & 102 & 98 \\
\hline Metolachlor & 4 & 64 & 122 & 103 \\
\hline Naphthalene $^{1}$ & 4 & 55 & 90 & 76 \\
\hline$p$-Cresol ${ }^{1}$ & 4 & 50 & 111 & 95 \\
\hline Pentachlorophenol & 4 & 31 & 86 & 72 \\
\hline Phenanthrene & 4 & 68 & 107 & 95 \\
\hline Phenol $^{1}$ & 4 & 67 & 189 & 155 \\
\hline Prometon & 4 & 54 & 122 & 98 \\
\hline Pyrene & 4 & 66 & 99 & 94 \\
\hline Tetrachloroethene $^{1}$ & 4 & 16 & 36 & 24 \\
\hline Tribromomethane $^{1}$ & 4 & 50 & 78 & 65 \\
\hline Tributyl phosphate & 4 & 48 & 143 & 105 \\
\hline Triclosan $^{1}$ & 4 & 52 & 100 & 95 \\
\hline Triethyl citrate & 4 & 54 & 120 & 109 \\
\hline Triphenyl phosphate $^{1}$ & 4 & 73 & 112 & 104 \\
\hline Tris(2-butoxyethyl) phosphate & 4 & 75 & 152 & 122 \\
\hline Tris(2-chloroethyl) phosphate & 4 & 64 & 120 & 107 \\
\hline Tris(dichloroisopropyl) phosphate & 4 & 73 & 112 & 101 \\
\hline
\end{tabular}

${ }^{\text {IC }}$ Constituent detected in ground-water samples. 
Table 8. Summary of surrogate recoveries for ground-water and quality-control analyses of volatile organic compounds, gasoline additives and (or) oxygenates, pesticides and (or) pesticide degradates, waste-water indicators, and constituents of special interest in samples collected for the North San Francisco Ground-Water Ambient Monitoring and Assessment (GAMA) study, California, August to November 2004.

\begin{tabular}{|c|c|c|c|c|c|c|}
\hline Surrogate & $\begin{array}{l}\text { Analytical } \\
\text { schedule }\end{array}$ & $\begin{array}{l}\text { Constituent } \\
\text { class }\end{array}$ & $\begin{array}{c}\text { Number of } \\
\text { analyses } \\
\text { (environmen- } \\
\text { tal, blank, } \\
\text { replicate) }\end{array}$ & $\begin{array}{c}\text { Number of } \\
\text { surrogate } \\
\text { recoveries } \\
\text { below } 70 \text { per- } \\
\text { cent (environ- } \\
\text { mental, blank, } \\
\text { replicate) }\end{array}$ & $\begin{array}{c}\text { Number of } \\
\text { surrogate } \\
\text { recoveries } \\
\text { between } \\
70 \text { and } 130 \\
\text { percent } \\
\text { (environmen- } \\
\text { tal, blank, } \\
\text { replicate) }\end{array}$ & $\begin{array}{c}\text { Number of } \\
\text { surrogate } \\
\text { recoveries } \\
\text { above } 130 \\
\text { percent } \\
\text { (environmen- } \\
\text { tal, blank, } \\
\text { replicate) }\end{array}$ \\
\hline 1,2-Dichloroethane-d4 & 2020 & Volatile organic compound & $89,13,18$ & $0,0,0$ & $89,13,18$ & $0,0,0$ \\
\hline 1-Bromo-4-fluorobenzene & 2020 & Volatile organic compound & $89,13,18$ & $0,0,0$ & $89,13,18$ & $0,0,0$ \\
\hline Toluene-d8 & 2020 & Volatile organic compound & $89,13,18$ & $0,0,0$ & $89,13,18$ & $0,0,0$ \\
\hline 1,2-Dichloroethane-d4 & 4024 & Gasoline additive/oxygenate & $89,13,18$ & $0,0,0$ & $89,13,18$ & $0,0,0$ \\
\hline 1-Bromo-4-fluorobenzene & 4024 & Gasoline additive/oxygenate & $89,13,18$ & $0,0,0$ & $89,13,18$ & $0,0,0$ \\
\hline Diazinon-d10 & 2003 & Pesticides and/or degradate & $87,11,19$ & $37,6,8$ & $50,5,11$ & $0,0,0$ \\
\hline $\begin{array}{l}\text { 2,4,5-T(2,4,5-trichlorophen- } \\
\quad \text { oxyacetic acid) }\end{array}$ & 2060 & Pesticides and/or degradate & $22,4,8$ & $0,0,1$ & $22,4,7$ & $0,0,0$ \\
\hline Barban & 2060 & Pesticides and/or degradate & $22,4,8$ & $1,0,0$ & $21,4,8$ & $0,0,0$ \\
\hline Caffeine- ${ }^{13} \mathrm{C}$ & 2060 & Pesticides and/or degradate & $22,4,8$ & $0,0,0$ & $13,1,3$ & $9,3,5$ \\
\hline Bisphenol A-d3 & 1433 & Waste-water indicator & $89,21,19$ & $87,21,19$ & $2,0,0$ & $0,0,0$ \\
\hline Caffeine $-{ }^{13} \mathrm{C}$ & 1433 & Waste-water indicator & $89,21,19$ & $13,4,4$ & $76,17,15$ & $0,0,0$ \\
\hline Decafluorobiphenyl & 1433 & Waste-water indicator & $89,21,19$ & $89,21,19$ & $0,0,0$ & $0,0,0$ \\
\hline
\end{tabular}

${ }^{1}$ Constituent analyzed at Montgomery Watson Harza Laboratory. 


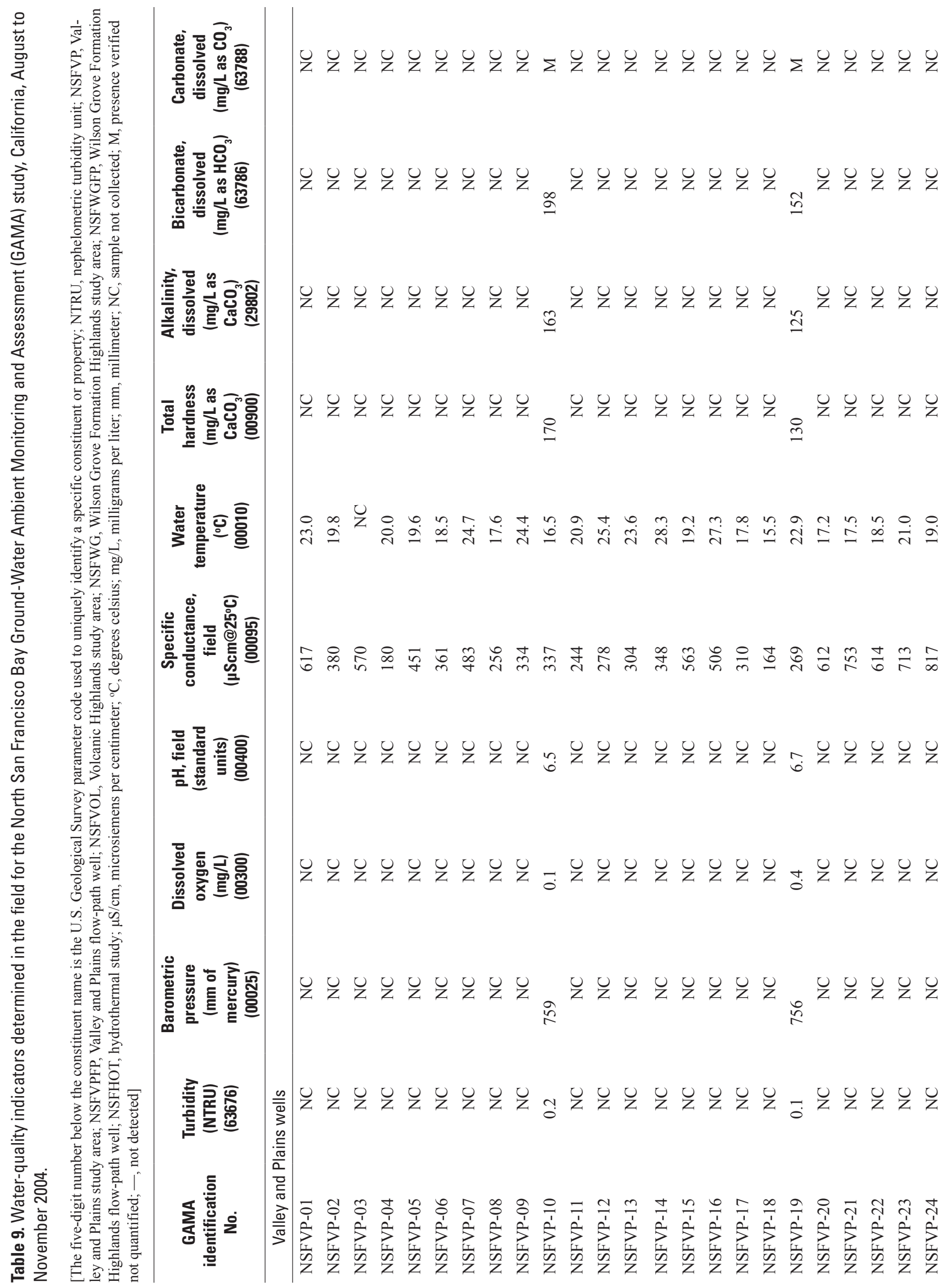




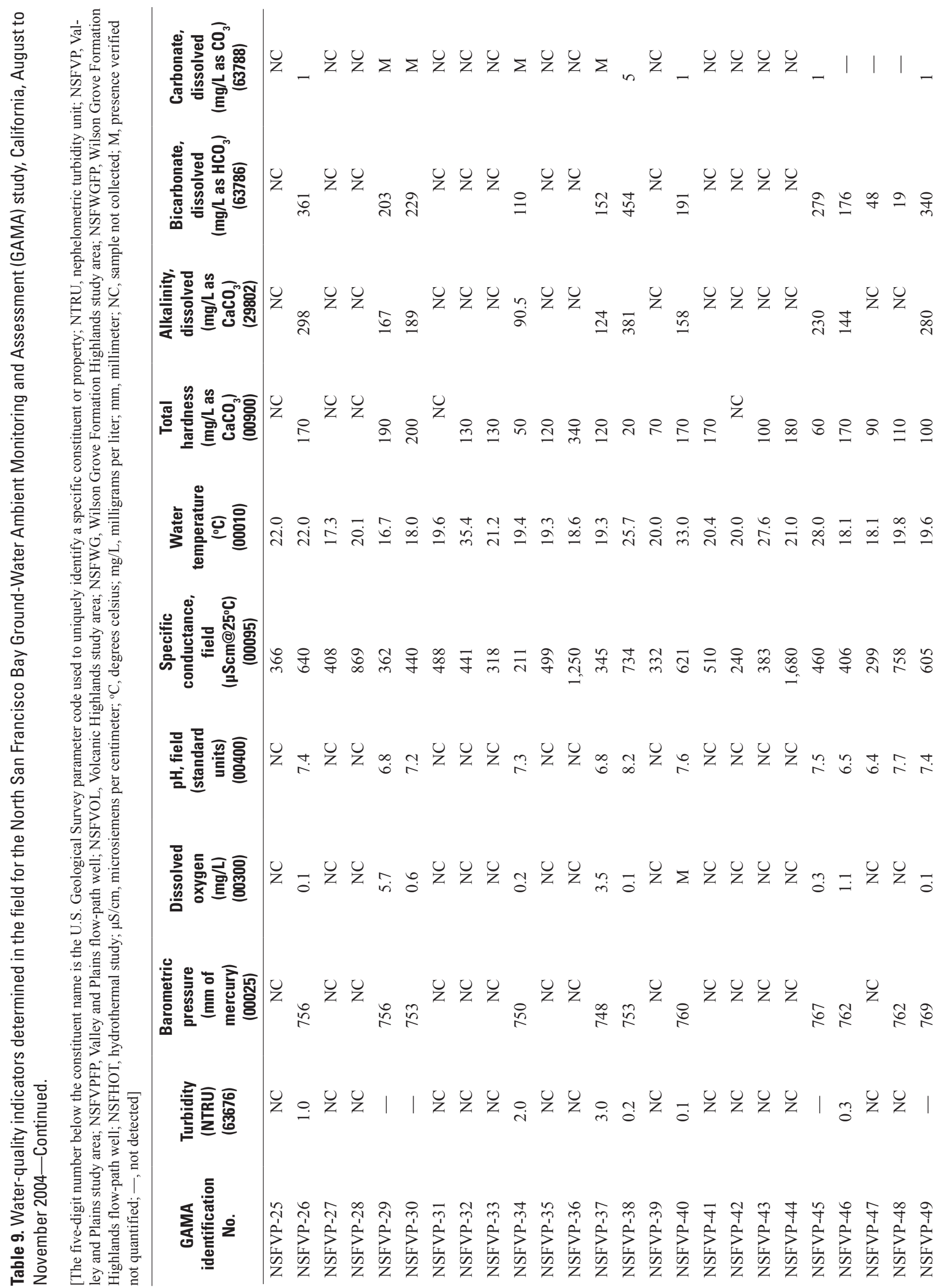




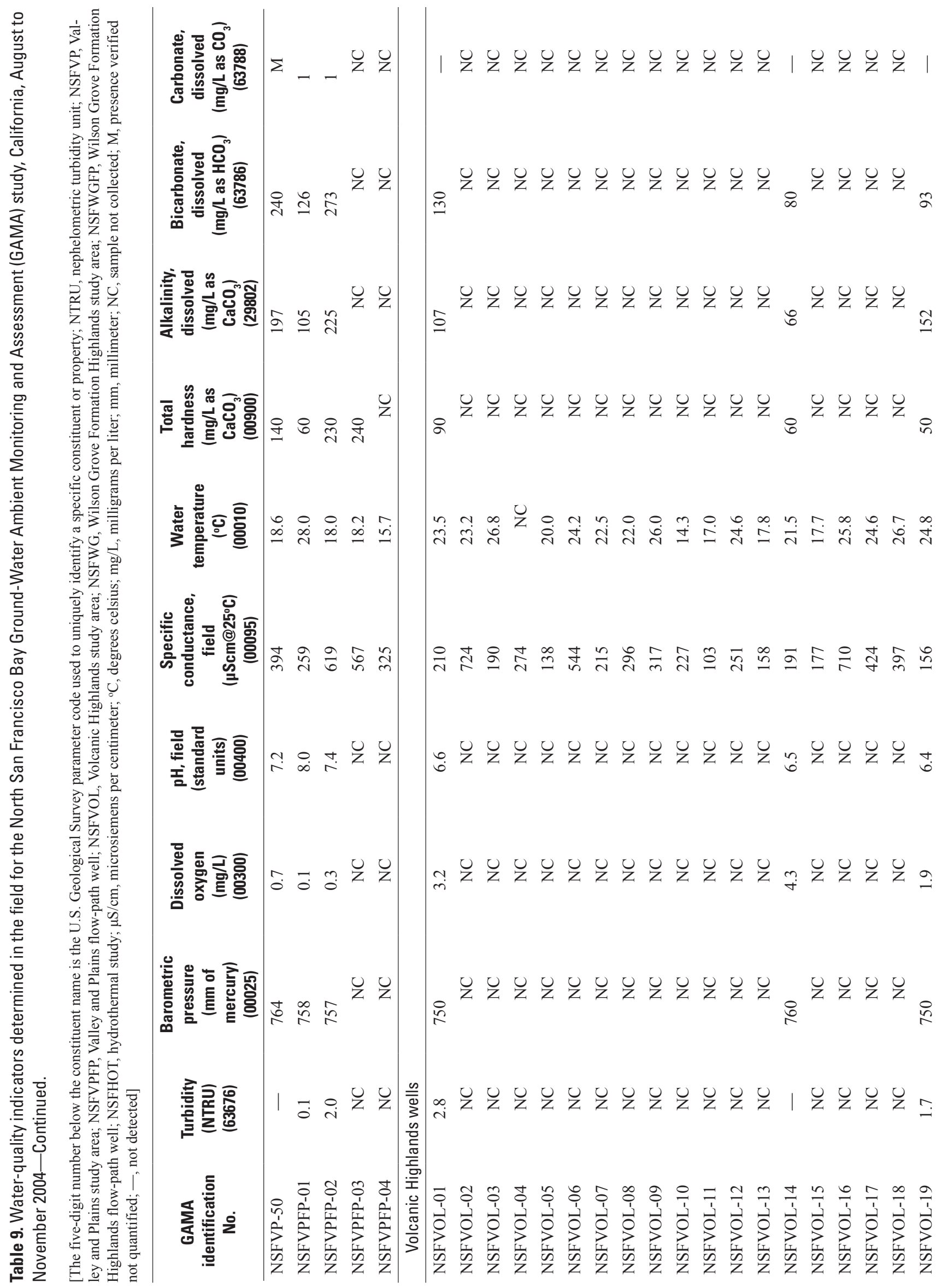




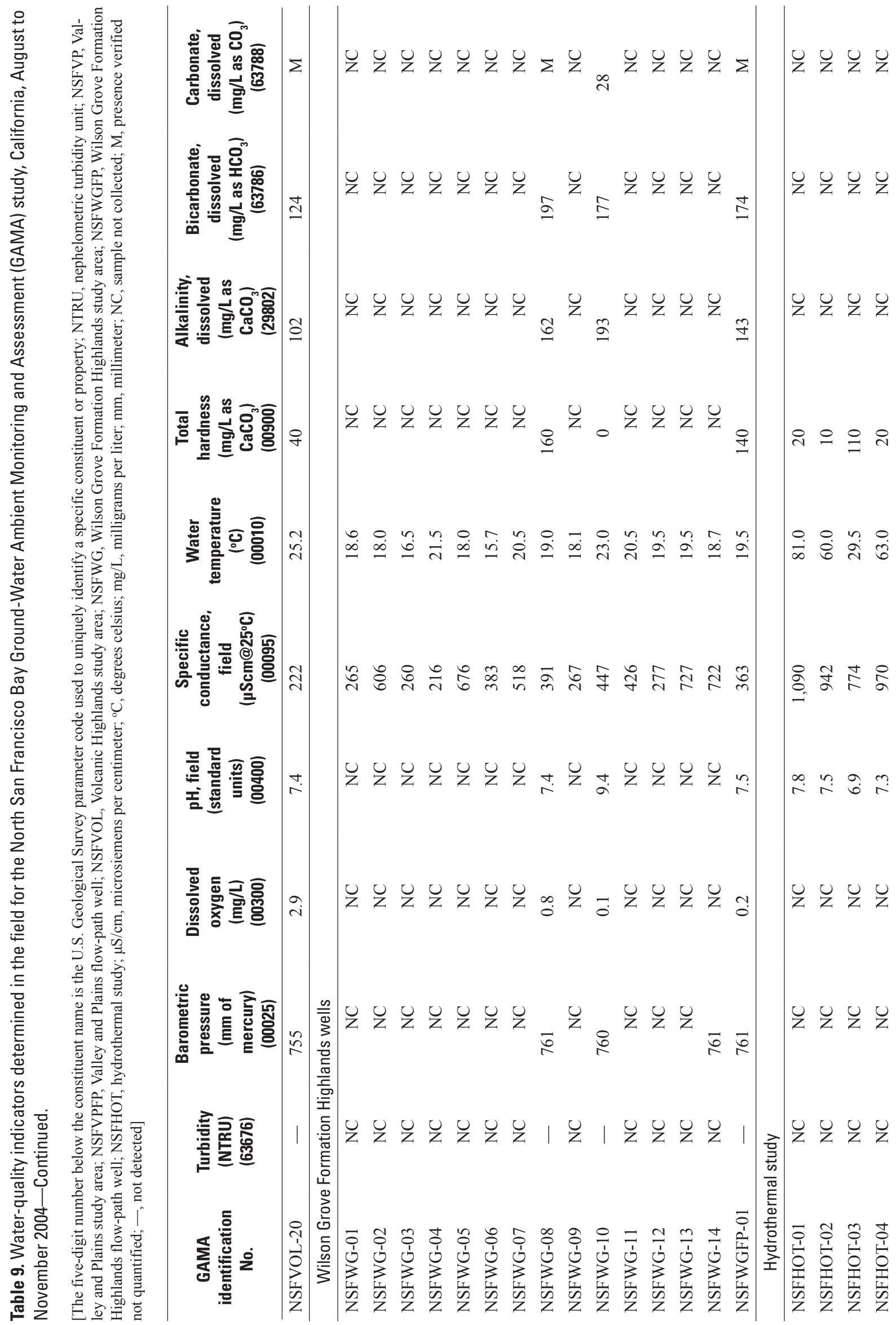




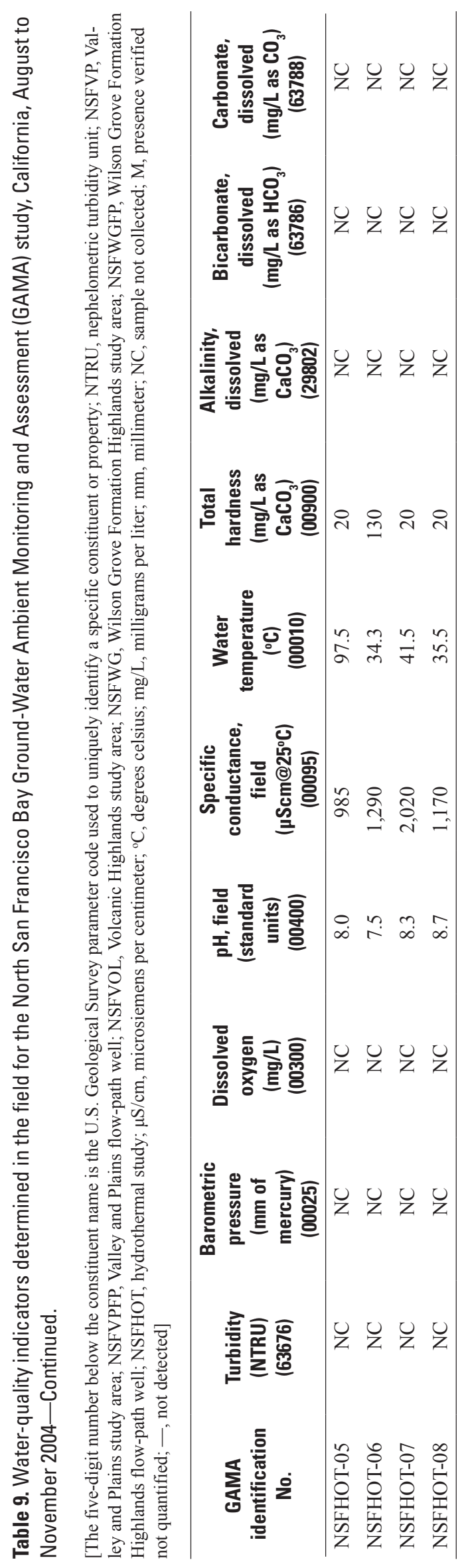


Table 10A. Results of analyses for volatile organic compounds (VOCs) and gasoline additives and (or) oxygenates in ground-water samples collected in the Valley and Plains study area of the North San Francisco Bay Ground-Water Ambient Monitoring and Assessment (GAMA) study, California, August to November 2004.

[The five-digit number in parentheses below the constituent name is the U.S. Geological Survey parameter code used to uniquely identify a specific constituent or property; LRL, laboratory reporting level; NSFVP, Valley and Plains study area; NSFVPFP, Valley and Plains flow-path well; $\mu \mathrm{g} / \mathrm{L}$, microgram per liter; E, estimated value; - , not detected; percentage values are detection frequencies]

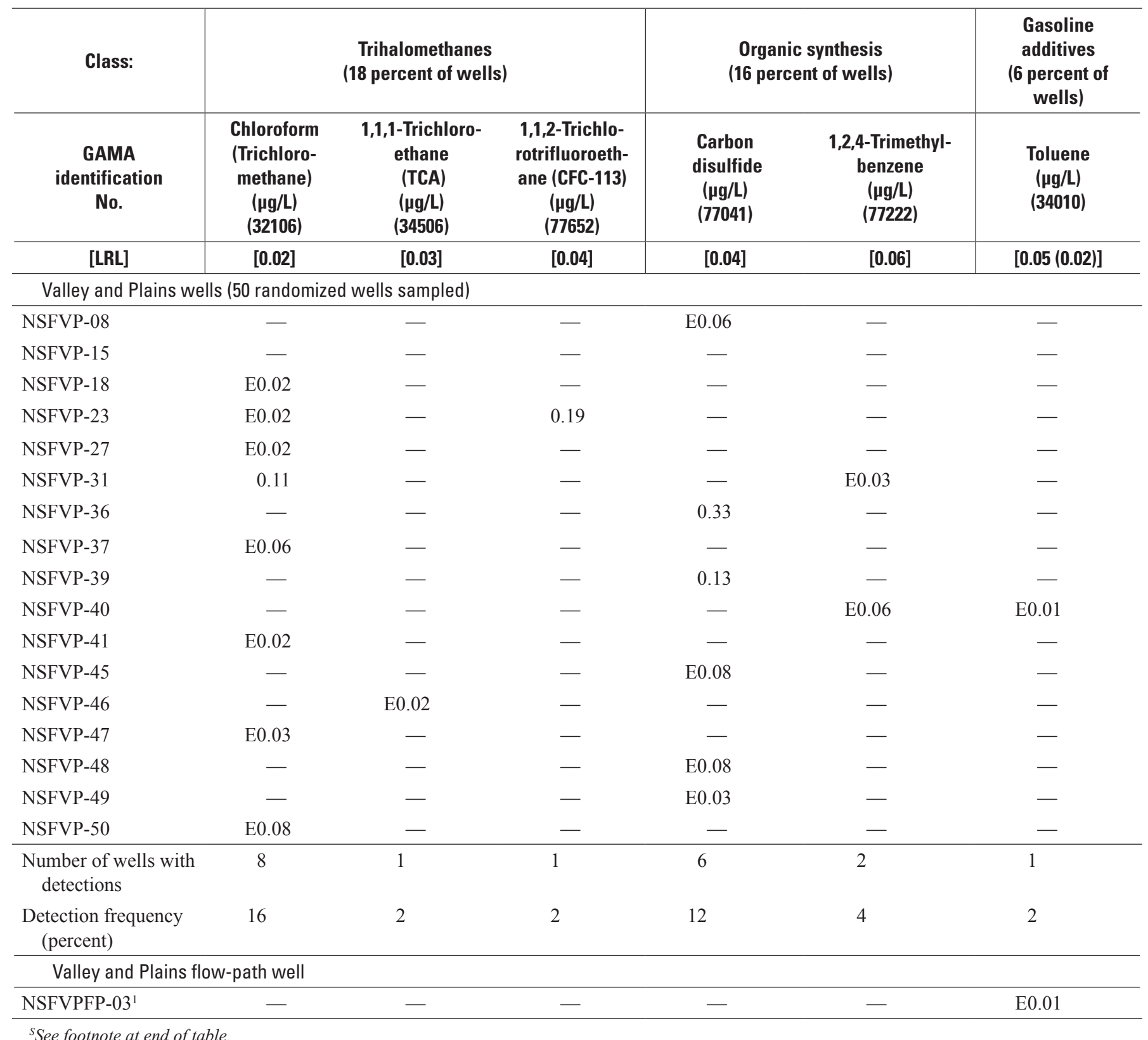

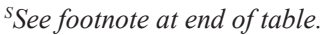


Table 10A. Results of analyses for volatile organic compounds (VOCs) and gasoline additives and (or) oxygenates in ground-water samples collected in the Valley and Plains study area of the North San Francisco Bay Ground-Water Ambient Monitoring and Assessment (GAMA) study, California, August to November 2004-Continued.

[The five-digit number in parentheses below the constituent name is the U.S. Geological Survey parameter code used to uniquely identify a specific constituent or property; LRL, laboratory reporting level; NSFVP, Valley and Plains study area; NSFVPFP, Valley and Plains flow-path well; $\mu \mathrm{g} / \mathrm{L}$, microgram per liter; E, estimated value; - , not detected; percentage values are detection frequencies]

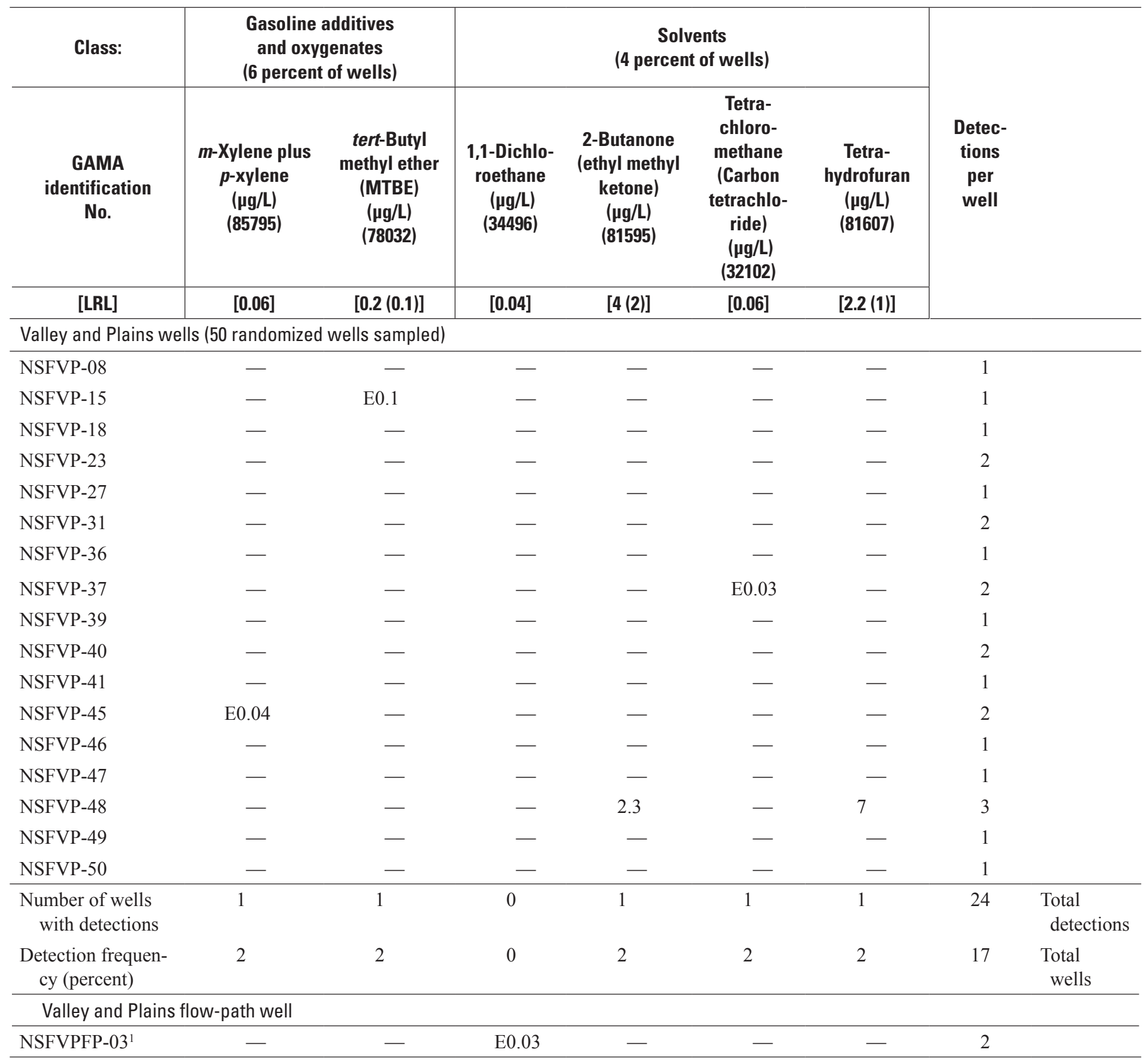

${ }^{1}$ Flowpath wells were not included in statistical calculations. 


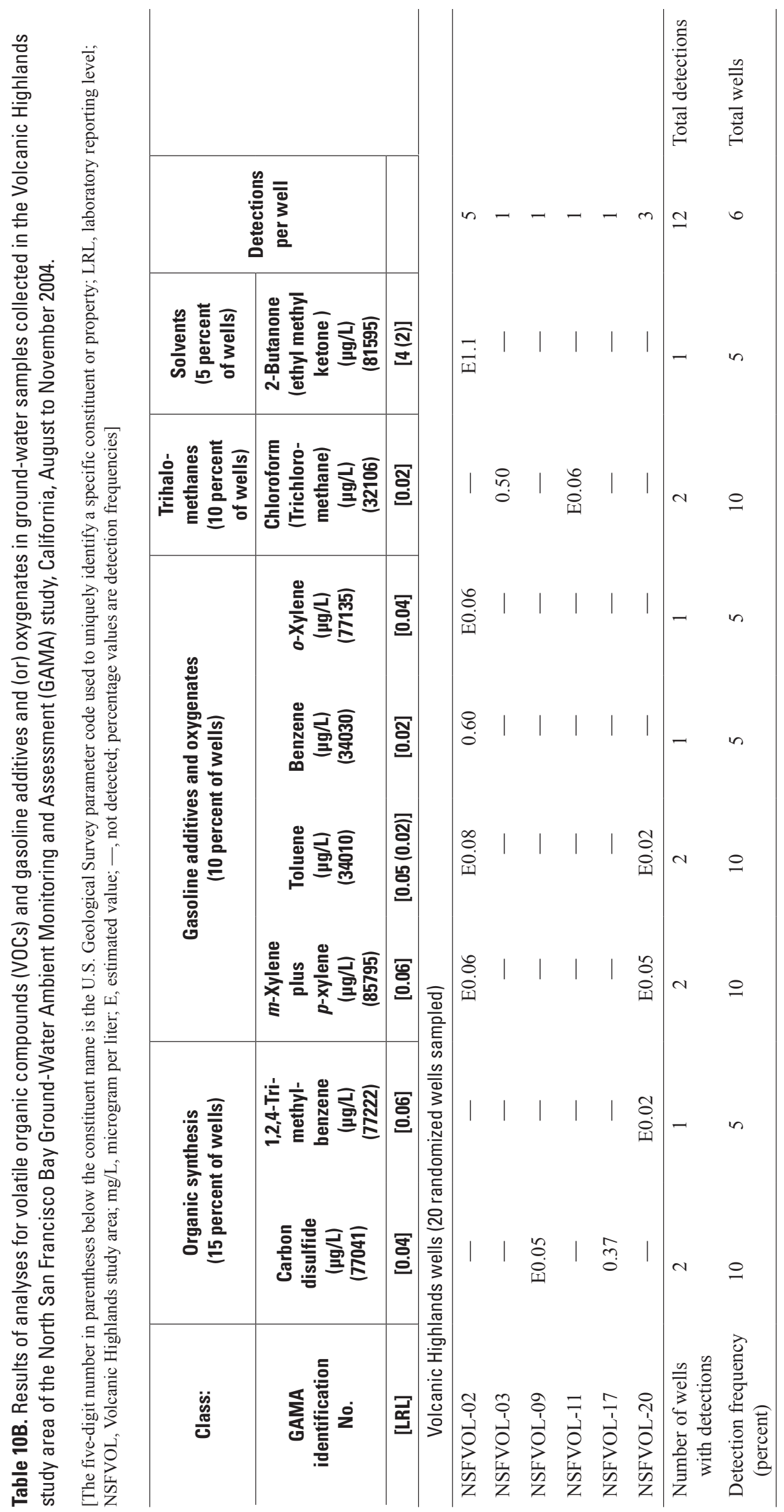




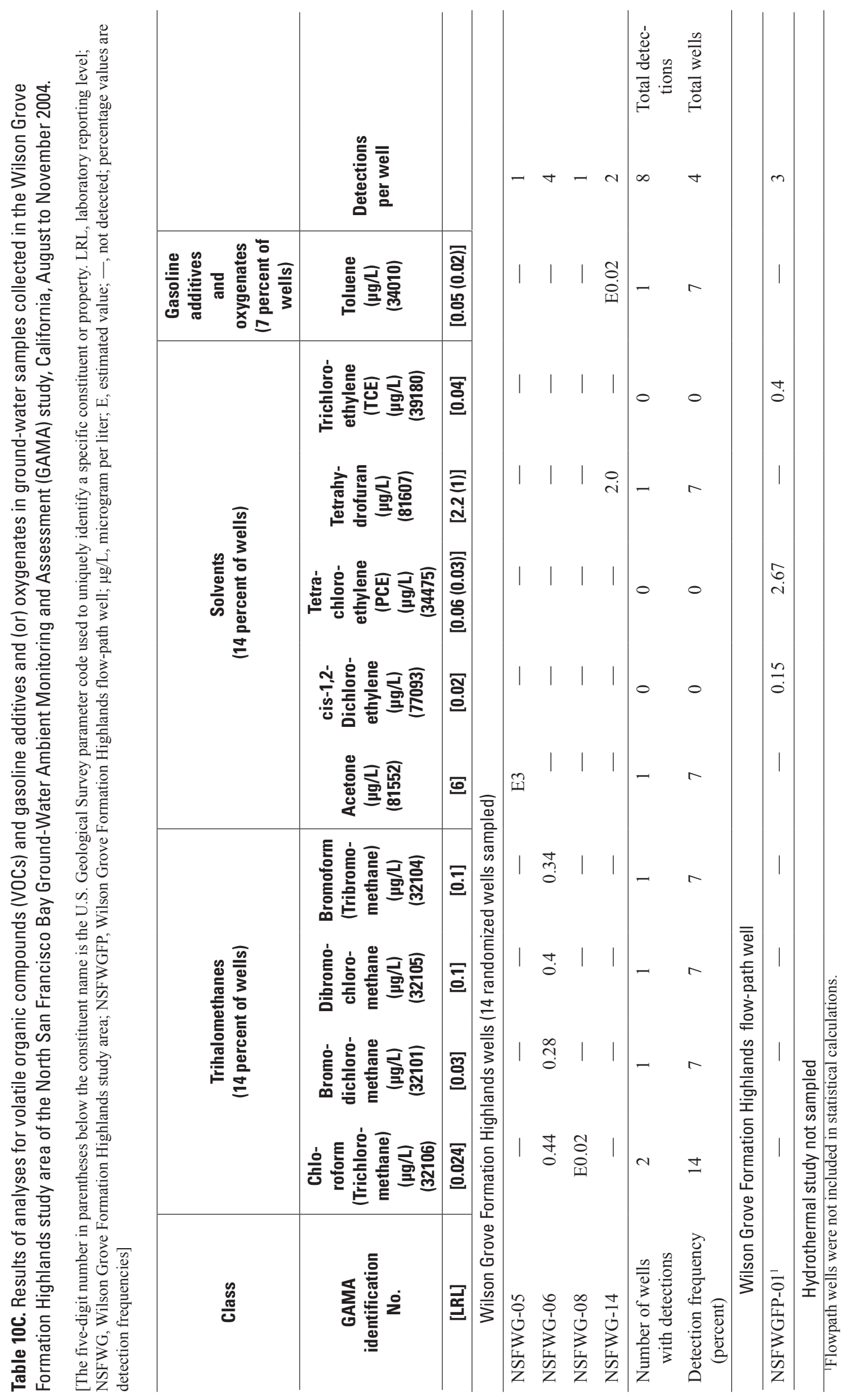




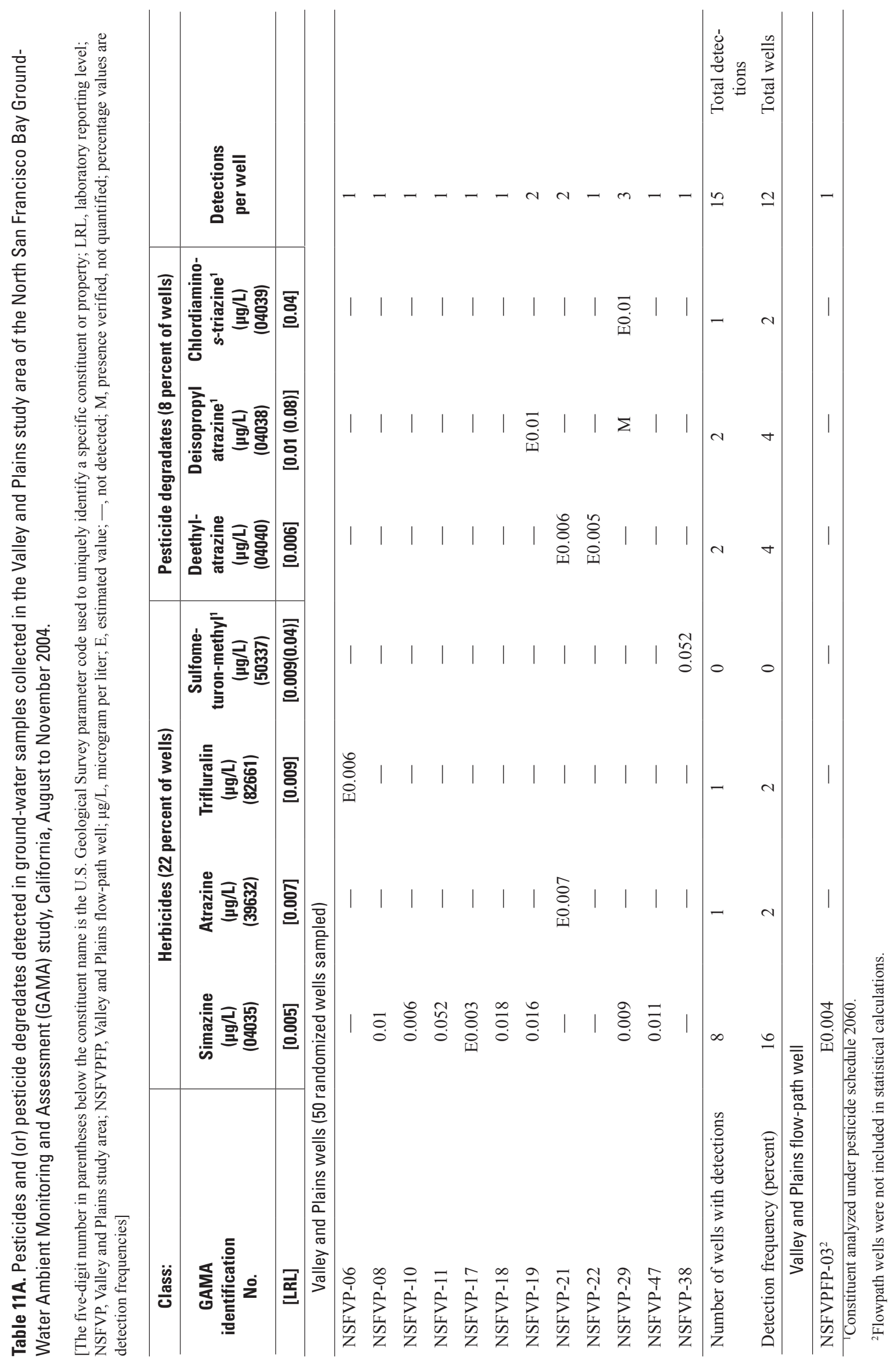


Table 11B. Pesticides and (or) pesticide degredates detected in ground-water samples collected in the Volcanic Highlands study area of the North San Francisco Bay Ground-Water Ambient Monitoring and Assessment (GAMA) study, California, August to November 2004.

[The five-digit number in parentheses below the constituent name is the U.S. Geological Survey parameter code used to uniquely identify a specific constituent or property; LRL, laboratory reporting level; NSFVOL, Volcanic Highlands study area; $\mu \mathrm{g} / \mathrm{L}$, microgram per liter; M, presence verified, not quantified; percentage values are detection frequencies]

\begin{tabular}{|c|c|c|c|}
\hline Class & Herbicide (5 percent of wells) & \multirow[b]{2}{*}{$\begin{array}{c}\text { Detections } \\
\text { per well }\end{array}$} & \\
\hline $\begin{array}{c}\text { GAMA } \\
\text { identification } \\
\text { No. }\end{array}$ & $\begin{array}{c}\text { Diphenamid' } \\
(\mu \mathrm{g} / \mathrm{L}) \\
(04033)\end{array}$ & & \\
\hline [LRL] & {$[0.01]$} & & \\
\hline \multicolumn{3}{|c|}{ Volcanic Highlands wells (20 wells sampled) } & \\
\hline Detection frequency (percent) & 5 & 1 & Total wells \\
\hline
\end{tabular}

${ }^{1}$ Constituent analyzed by pesticide schedule 2060 .

Table 11C. Pesticides and (or) pesticide degradates detected in ground-water samples collected in the Wilson Grove Formation Highlands study area of the North San Francisco Bay Ground-Water Ambient Monitoring and Assessment (GAMA) study, California, August to November 2004.

[The five-digit number in parentheses below the constituent name is the U.S. Geological Survey parameter code used to uniquely identify a specific constituent or property; LRL, laboratory reporting level; NSFWG, Wilson Grove Formation Highlands study area; NSFWGFP, Wilson Grove Formation Highlands flow-path well; $\mu \mathrm{g} / \mathrm{L}$, microgram per liter; E, estimated value; —, not Formation detected; percentage values are detection frequencies]

\begin{tabular}{|c|c|c|c|c|}
\hline Class & \multicolumn{2}{|c|}{ Herbicides (7 percent of wells) } & \multirow[b]{2}{*}{$\begin{array}{c}\text { Detections } \\
\text { per well }\end{array}$} & \\
\hline $\begin{array}{c}\text { GAMA } \\
\text { identification } \\
\text { No. }\end{array}$ & $\begin{array}{c}\text { Diazinon } \\
\text { ( } \mu \mathrm{g} / \mathrm{L}) \\
(39572)\end{array}$ & $\begin{array}{c}\text { Atrazine } \\
(\mu \mathrm{g} / \mathrm{L}) \\
(39632)\end{array}$ & & \\
\hline [LRL] & {$[0.005]$} & {$[0.007]$} & & \\
\hline \multicolumn{4}{|c|}{ Wilson Grove Formation Highlands wells (14 randomized wells sampled) } & \\
\hline Detection frequency (percent) & 7 & 0 & 1 & Total wells \\
\hline \multicolumn{5}{|c|}{ Wilson Grove Formation Highlands flow-path well } \\
\hline NSFWGFP-0 $1^{1}$ & - & E0.006 & 1 & \\
\hline
\end{tabular}

${ }^{1}$ Flowpath wells were not included in statistical calculations. 
Table 12A. Waste-water indicators measured in ground-water samples collected in the Valley and Plains study area of the North San Francisco Bay Ground-Water Ambient Monitoring and Assessment (GAMA) study, California, August to November 2004.

[The five-digit number in parentheses below the compound name is the U.S. Geological Survey parameter code used to uniquely identify a specific constituent or property; LRL, laboratory reporting level; NSFVP, Valley and Plains study area; NSFVPFP, Valley and Plains flow-path well; $\mu \mathrm{g} / \mathrm{L}$, microgram per liter; E, estimated value; - , not detected; V, value censored due to contamination and not included in ground-water quality analyses; M, presence verified but not quantified]

\begin{tabular}{|c|c|c|c|c|c|c|c|c|}
\hline $\begin{array}{c}\text { GAMA } \\
\text { identi- } \\
\text { fication } \\
\text { No. }\end{array}$ & $\begin{array}{c}\text { Phenol}^{1} \\
\text { ( } \mu \mathrm{gg} / \mathrm{L}) \\
(34466)\end{array}$ & $\begin{array}{c}\text { Caffeine }^{2} \\
(\mu \mathrm{g} / \mathrm{L}) \\
(\mathbf{5 0 3 0 5})\end{array}$ & $\begin{array}{c}\text { Isophorone } \\
\text { ( } \mu \mathrm{g} / \mathrm{L}) \\
(34409)\end{array}$ & $\begin{array}{c}\text { Triclosan } \\
(\mu \mathrm{g} / \mathrm{L}) \\
(62090)\end{array}$ & $\begin{array}{c}\text { Tetrachloro- } \\
\text { ethylene } \\
(\mu \mathrm{g} / \mathrm{L}) \\
(34476)\end{array}$ & $\begin{array}{c}\text { Bromo- } \\
\text { form } \\
(\mu \mathrm{g} / \mathrm{L}) \\
(34288)\end{array}$ & $\begin{array}{c}\text { Detec- } \\
\text { tions } \\
\text { per well }\end{array}$ & \\
\hline [LRL] & {$[0.5]$} & {$[0.010(0.5)]$} & [0.5] & [1] & {$[0.5]$} & {$[0.5]$} & & \\
\hline \multicolumn{9}{|c|}{ Valley and Plains wells (50 randomized wells sampled) } \\
\hline NSFVP-12 & VE0.4 & - & - & - & - & - & 0 & \\
\hline NSFVP-14 & V0.8 & - & - & M & - & - & 1 & \\
\hline NSFVP-15 & V1.1 & $\mathrm{M}$ & - & - & - & - & 1 & \\
\hline NSFVP-18 & V0.9 & - & - & - & - & - & 0 & \\
\hline NSFVP-20 & V0.8 & - & - & - & - & - & 0 & \\
\hline NSFVP-21 & VE0.4 & - & - & - & $\mathrm{M}$ & - & 1 & \\
\hline NSFVP-29 & V1.3 & - & - & $\mathrm{M}$ & $\mathrm{M}$ & - & 2 & \\
\hline NSFVP-31 & VE0.3 & - & - & - & - & $\mathrm{M}$ & 1 & \\
\hline NSFVP-32 & V1.6 & - & - & - & - & - & 0 & \\
\hline NSFVP-34 & VE0.3 & - & - & - & - & - & 0 & \\
\hline NSFVP-35 & V1.0 & - & - & - & - & - & 0 & \\
\hline NSFVP-36 & V0.5 & - & - & - & - & - & 0 & \\
\hline NSFVP-37 & - & - & - & - & - & E0.5 & 1 & \\
\hline NSFVP-38 & $\mathrm{V} 2.0$ & 0.067 & - & - & - & - & 1 & \\
\hline NSFVP-39 & V0.7 & - & $\mathrm{M}$ & - & - & - & 1 & \\
\hline NSFVP-40 & VE0.4 & - & M & - & - & - & 1 & \\
\hline $\begin{array}{l}\text { Detection frequency } \\
\text { (percent })^{3}\end{array}$ & $0^{1}$ & 8 & 6 & 4 & 4 & 4 & 12 & Total wells \\
\hline \multicolumn{9}{|c|}{ Valley and Plains flow-path well } \\
\hline NSFVPFP- $01^{3}$ & VE0.4 & - & - & M & - & - & 1 & \\
\hline NSFVPFP- $02^{3}$ & - & 0.017 & - & - & - & - & 1 & \\
\hline NSFVPFP-03 ${ }^{3}$ & V1.0 & - & $\mathrm{M}$ & - & - & - & 1 & \\
\hline NSFVPFP- $04^{3}$ & V0.7 & - & - & - & - & - & 0 & \\
\hline
\end{tabular}

${ }^{1}$ Due to high phenol contents in the blank samples, phenol detecions have been censored.

${ }^{2}$ Caffeine concentraion determined by the preferred analysis method, pesticide analytical schedule 2060.

${ }^{3}$ Flowpath wells were not included in statistical calculations. 


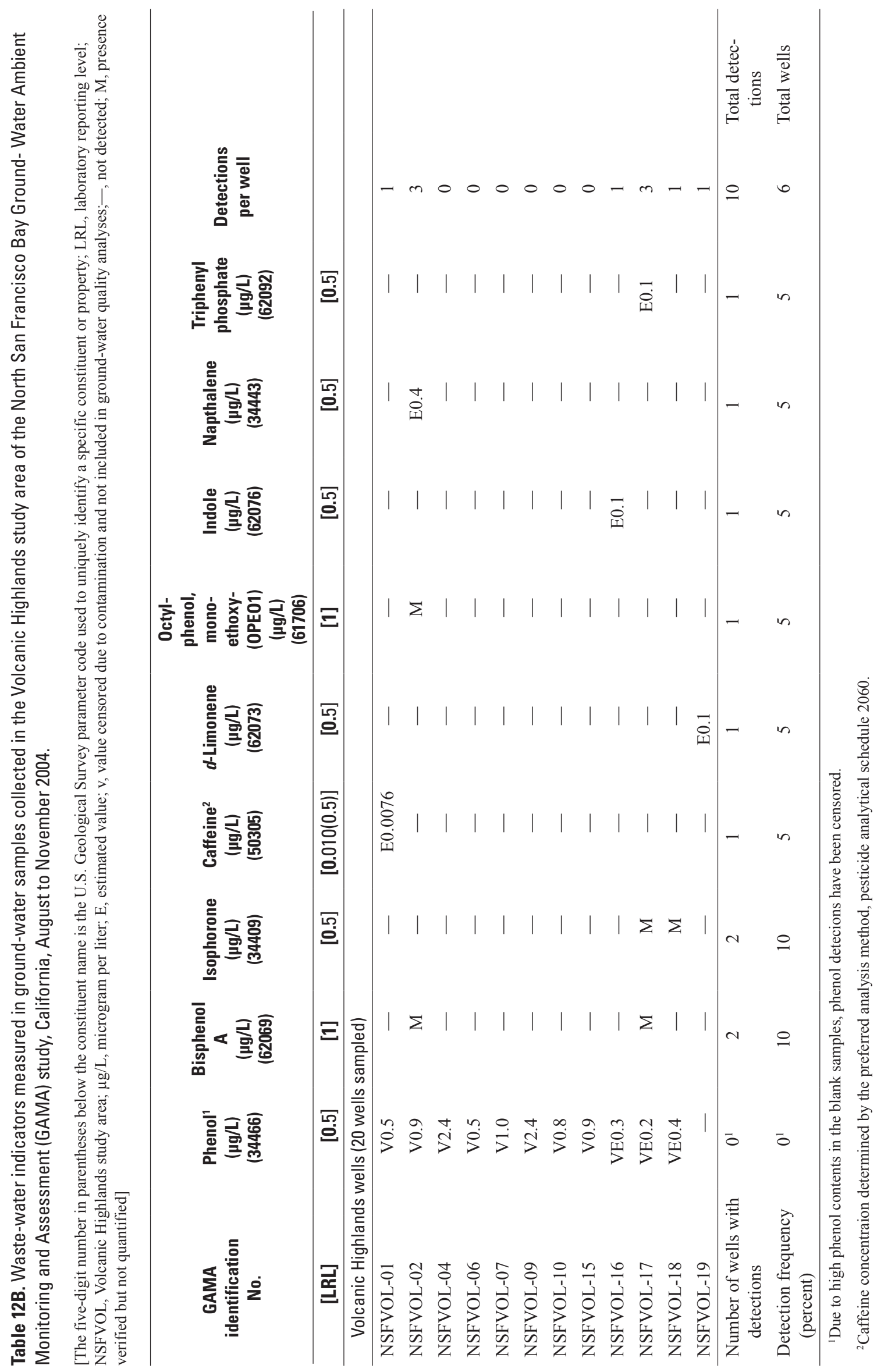




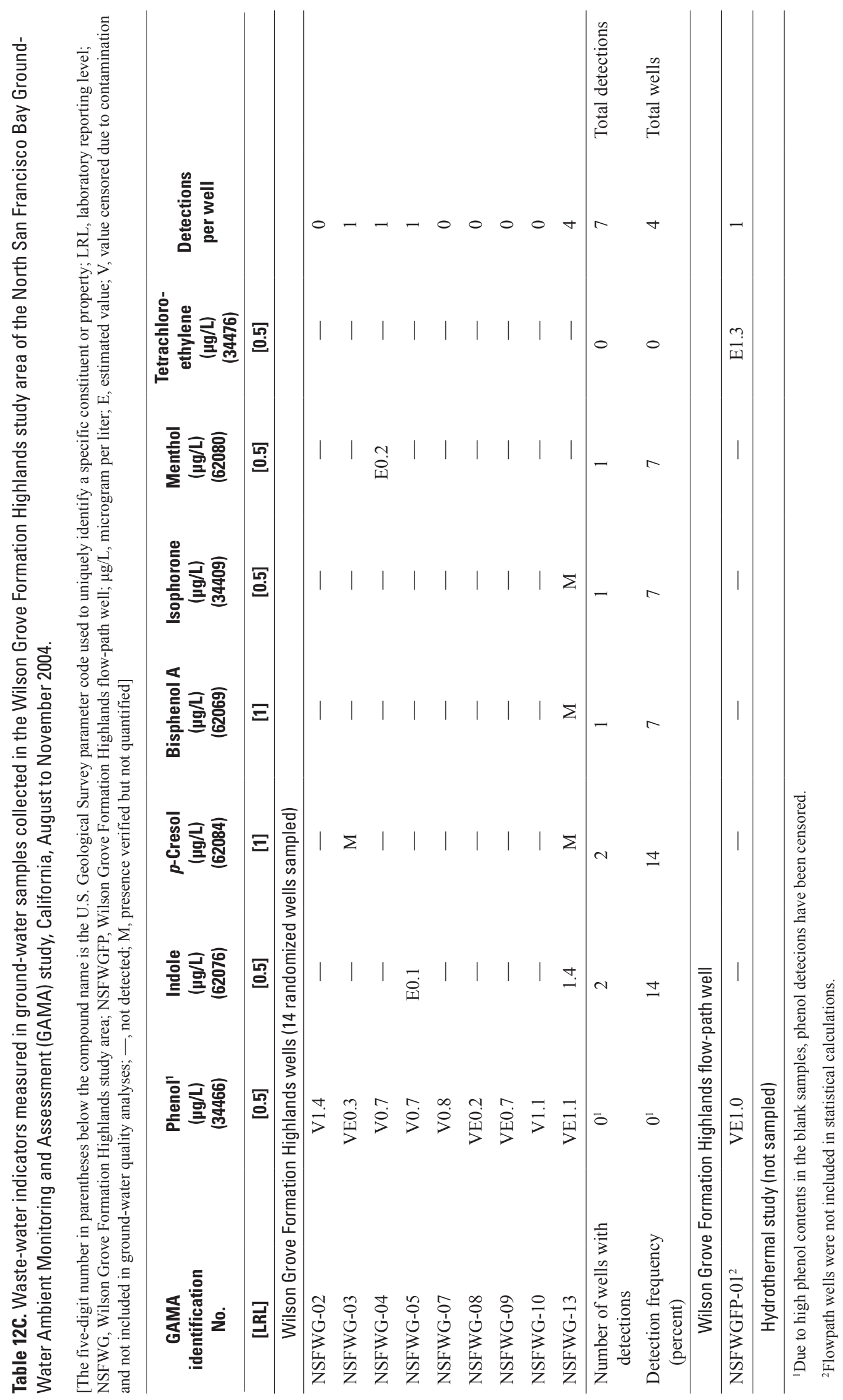


Table 13. Results of analyses for the constituents of special interest: perchlorate, trichloropropane (1,2,3-TCP), N-nitrosodimethylamine (NDMA) in ground-water samples collected for the North San Francisco Bay Ground-Water Ambient Monitoring and Assessment (GAMA) study, California, August to November 2004.

[MRL, minimum reporting level; $\mu \mathrm{g} / \mathrm{L}$, micrograms per liter]

\begin{tabular}{|c|c|c|c|}
\hline $\begin{array}{c}\text { GAMA } \\
\text { identification } \\
\text { No. }\end{array}$ & $\begin{array}{c}\text { Perchlorate } \\
(\mu \mathrm{g} / \mathrm{L})\end{array}$ & $\begin{array}{c}\text { 1,2,3-Trichlor- } \\
\text { propane } \\
(\mu \mathrm{g} / \mathrm{L})\end{array}$ & $\begin{array}{c}\text { N-nitroso- } \\
\text { dimethylamine } \\
\text { (NDMA) } \\
(\mu \mathrm{g} / \mathrm{L})\end{array}$ \\
\hline Valley and Plains wells & Not detected & Not detected & Not detected \\
\hline Volcanic Highlands wells & Not detected & Not detected & Not detected \\
\hline Wilson Grove Formation Highlands wells & Not detected & Not detected & Not detected \\
\hline Hydrothermal study & Not sampled & Not sampled & Not sampled \\
\hline
\end{tabular}


Table 14. Nutrients and dissolved organic carbon in ground-water samples collected for the North San Francisco Bay Ground-Water Ambient Monitoring and Assessment (GAMA) study, California, August to November 2004.

[The five-digit number in parentheses below the constituent name is the U.S. Geological Survey parameter code used to uniquely identify a specific constituent or property; LRL, laboratory reporting level; mg/L, milligram per liter; NSFVP, Valley and Plains study area; NSFVPFP, Valley and Plains flow-path well; NSFVOL, Volcanic Highlands study area; NSFWG, Wilson Grove Formation Highlands study area; NSFWGFP, Wilson Grove Formation Highlands flow-path well; E, estimated value; V, value censored due to contamination and not included in ground-water quality analyses; - , not detected]

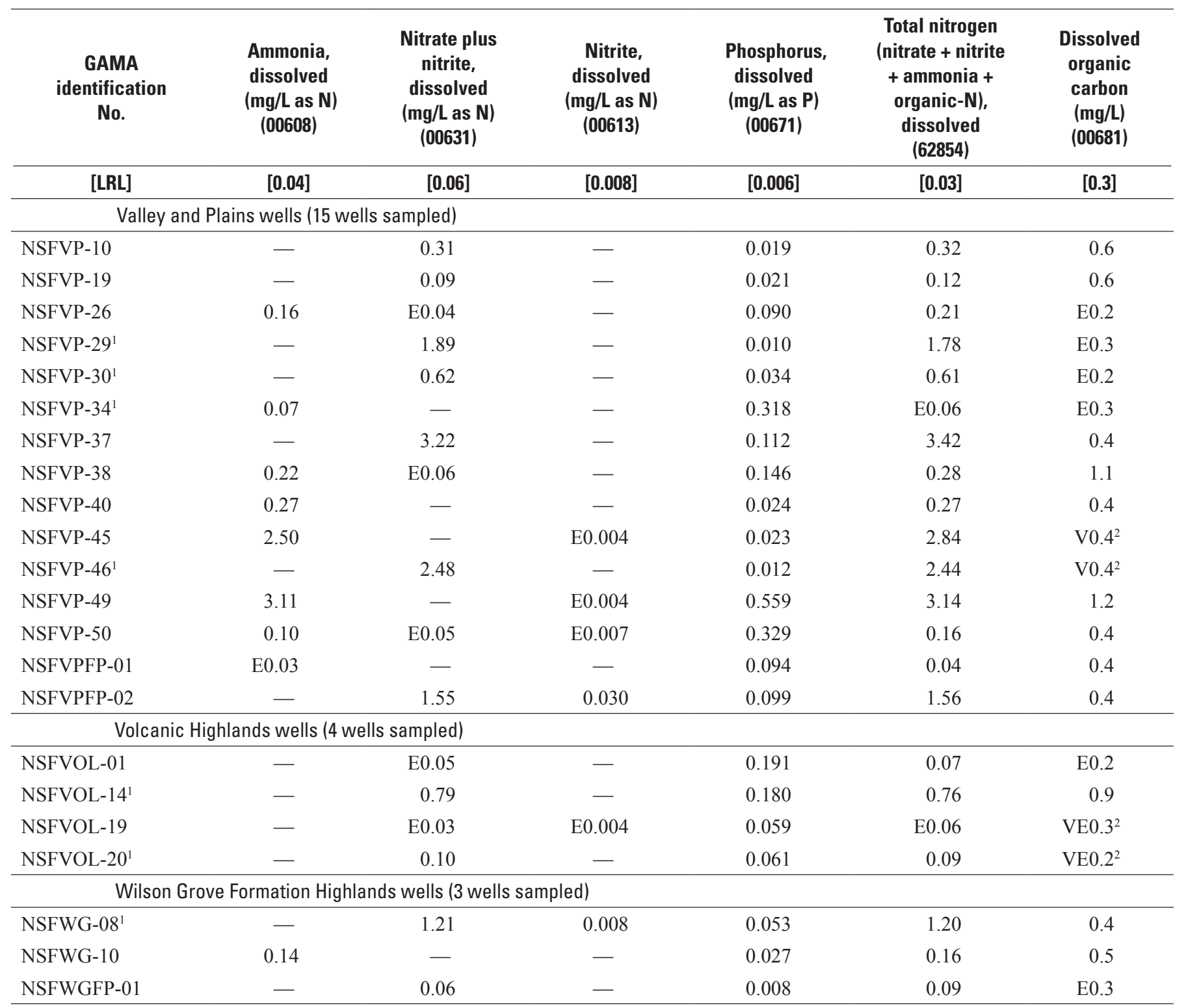

${ }^{1}$ Total nitrogen in these samples is less than the sum of the filtered nitrogen analytes but falls within the U.S. Geological Survey National Water Quality Laboratory acceptance criteria of a 10-percent relative percent difference.

${ }^{2}$ Detection in blank, value censored. 


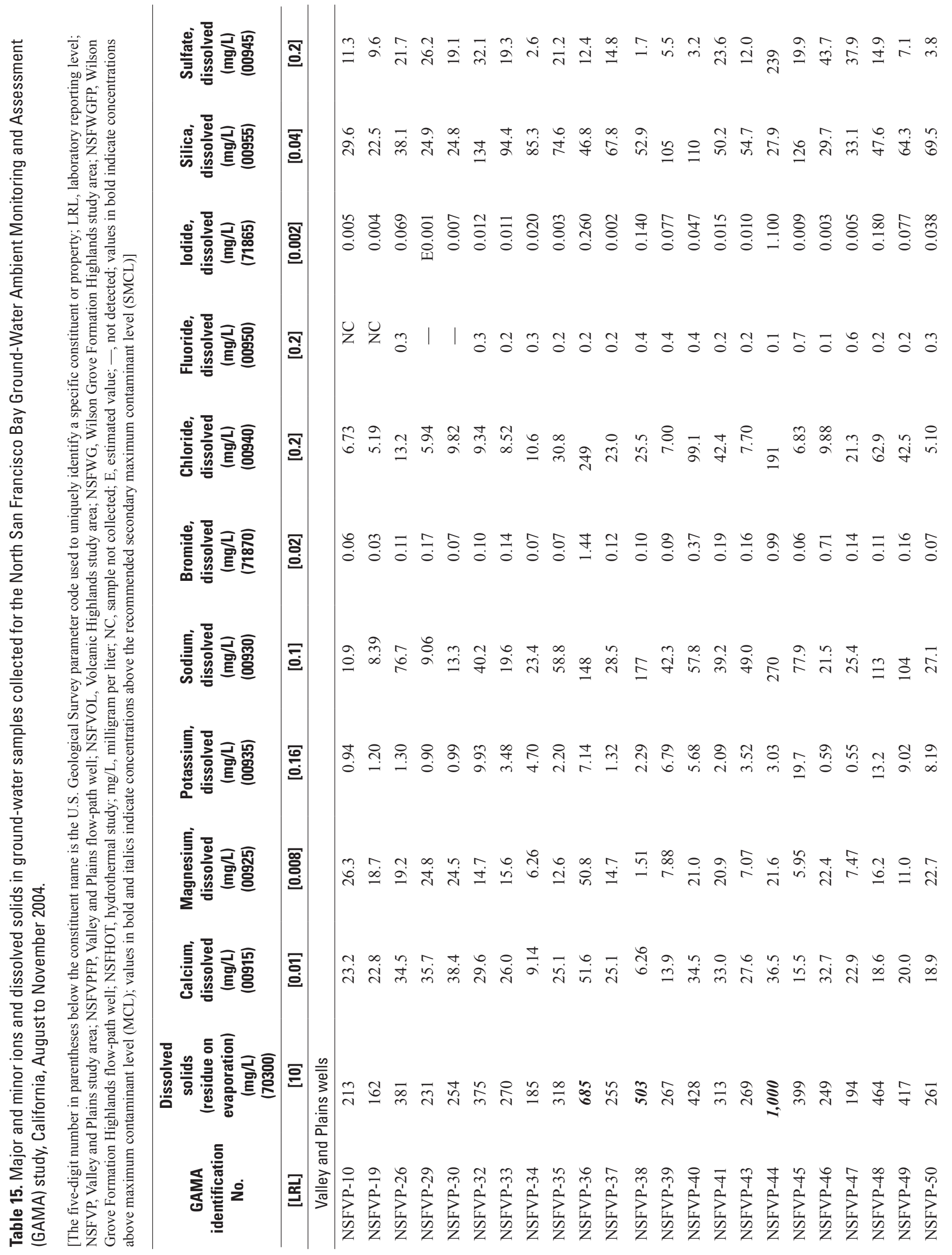




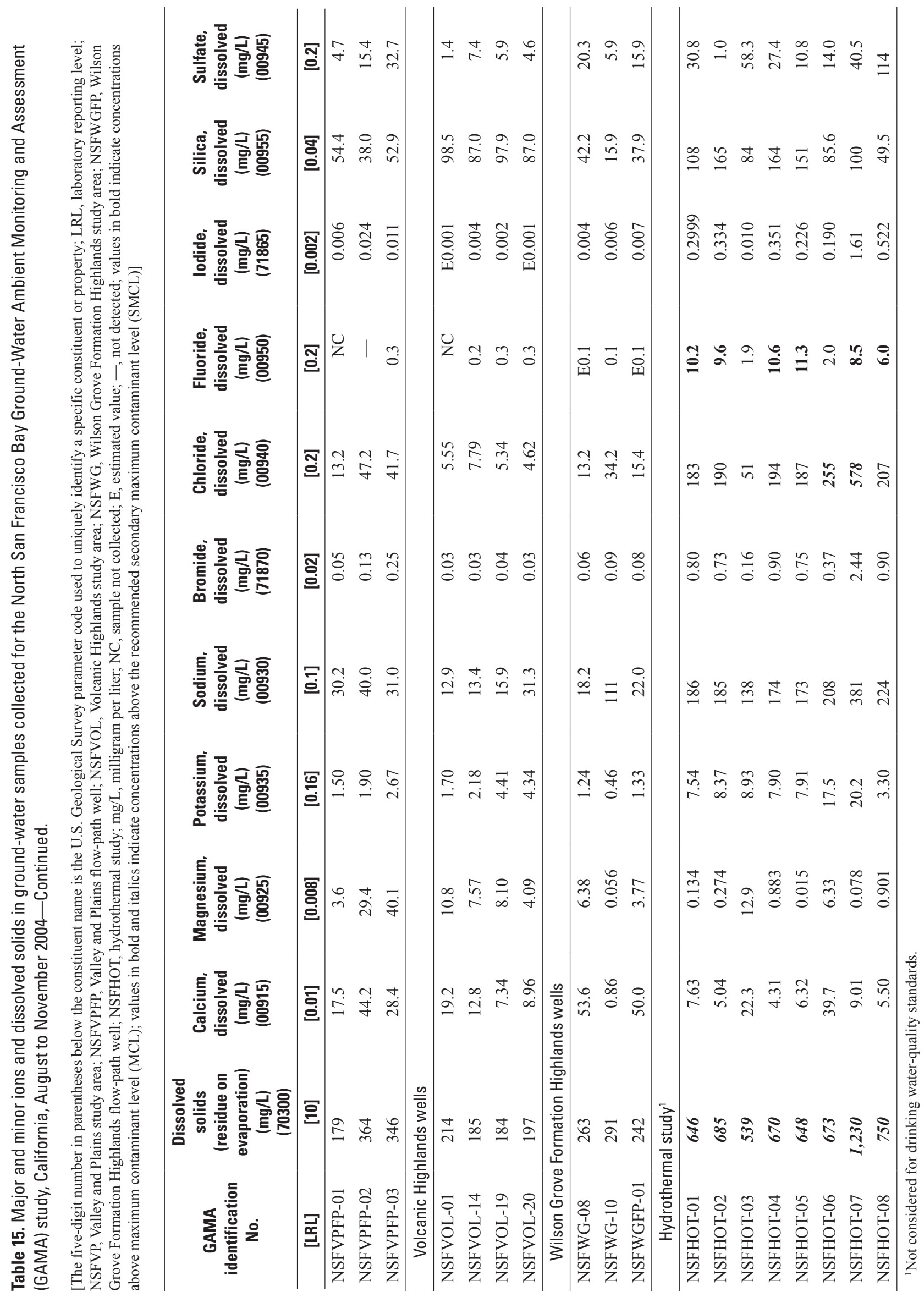




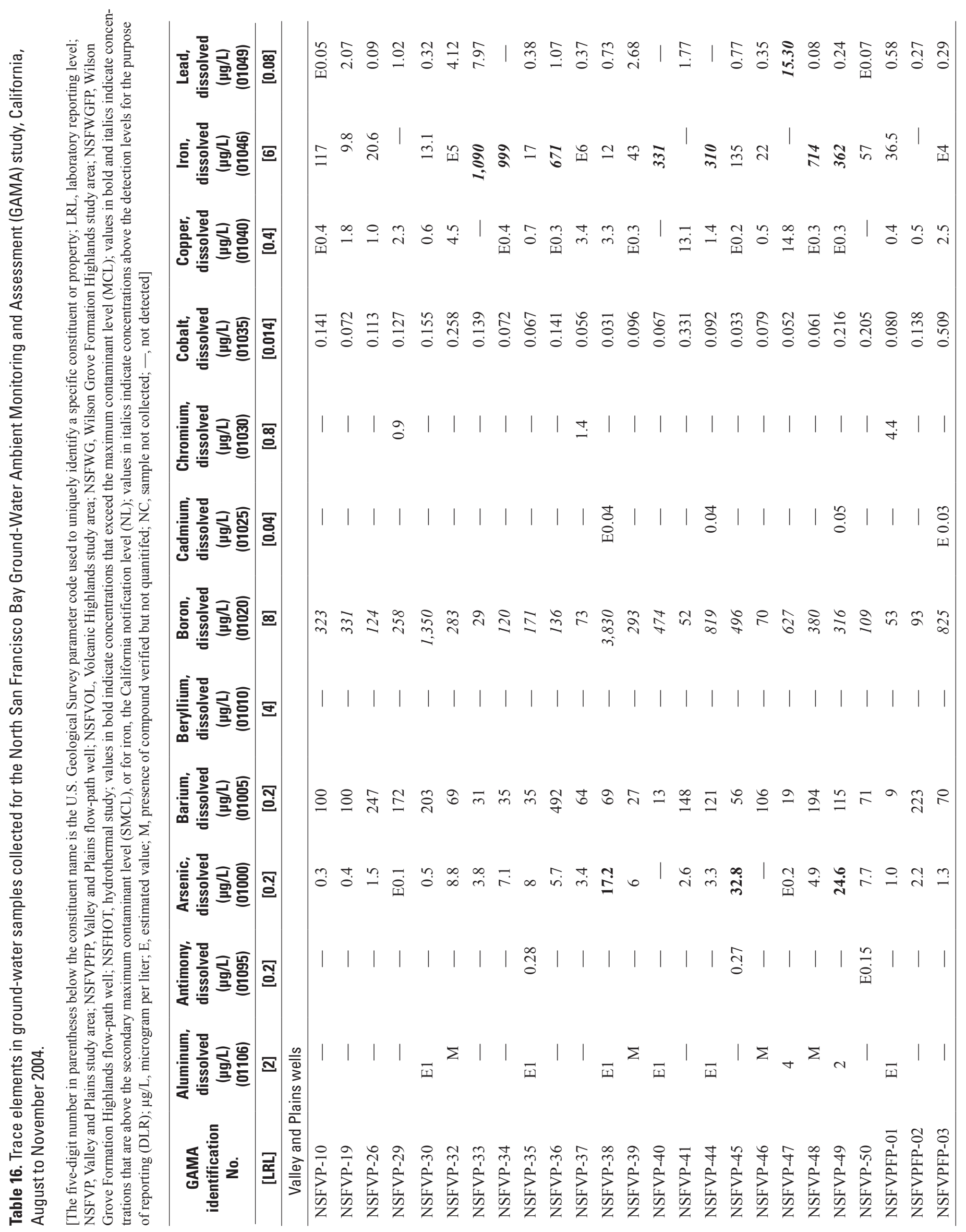




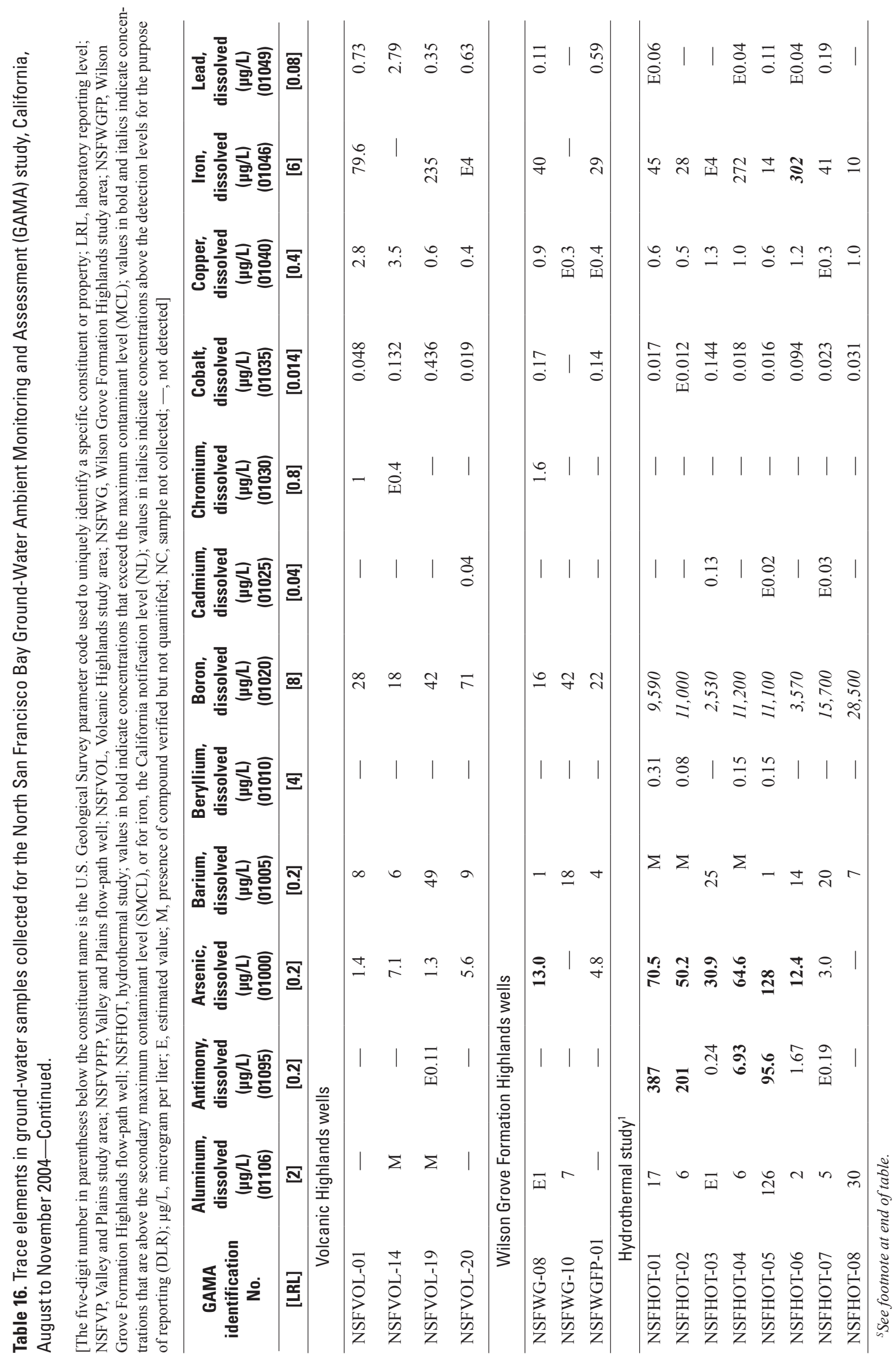




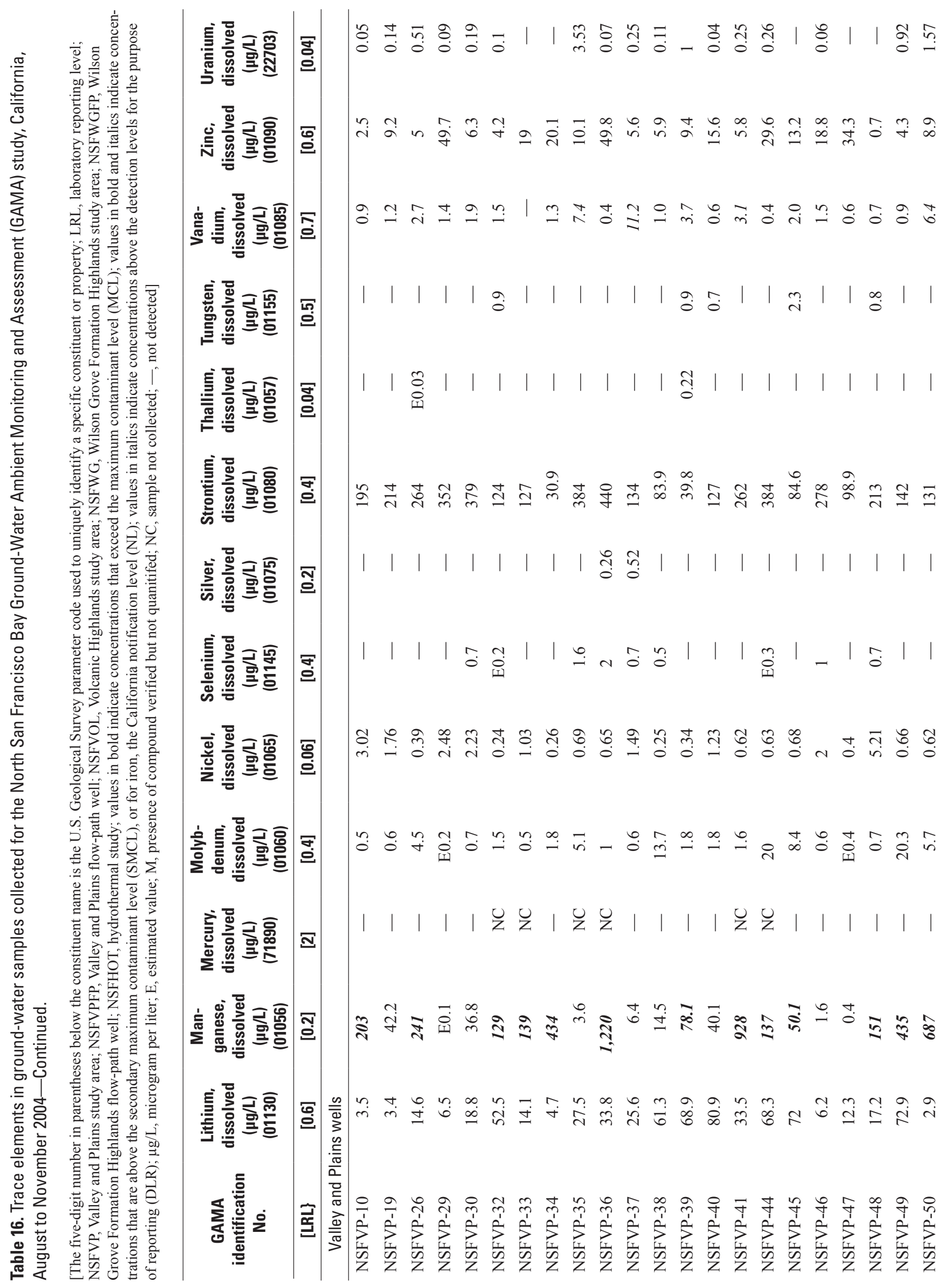




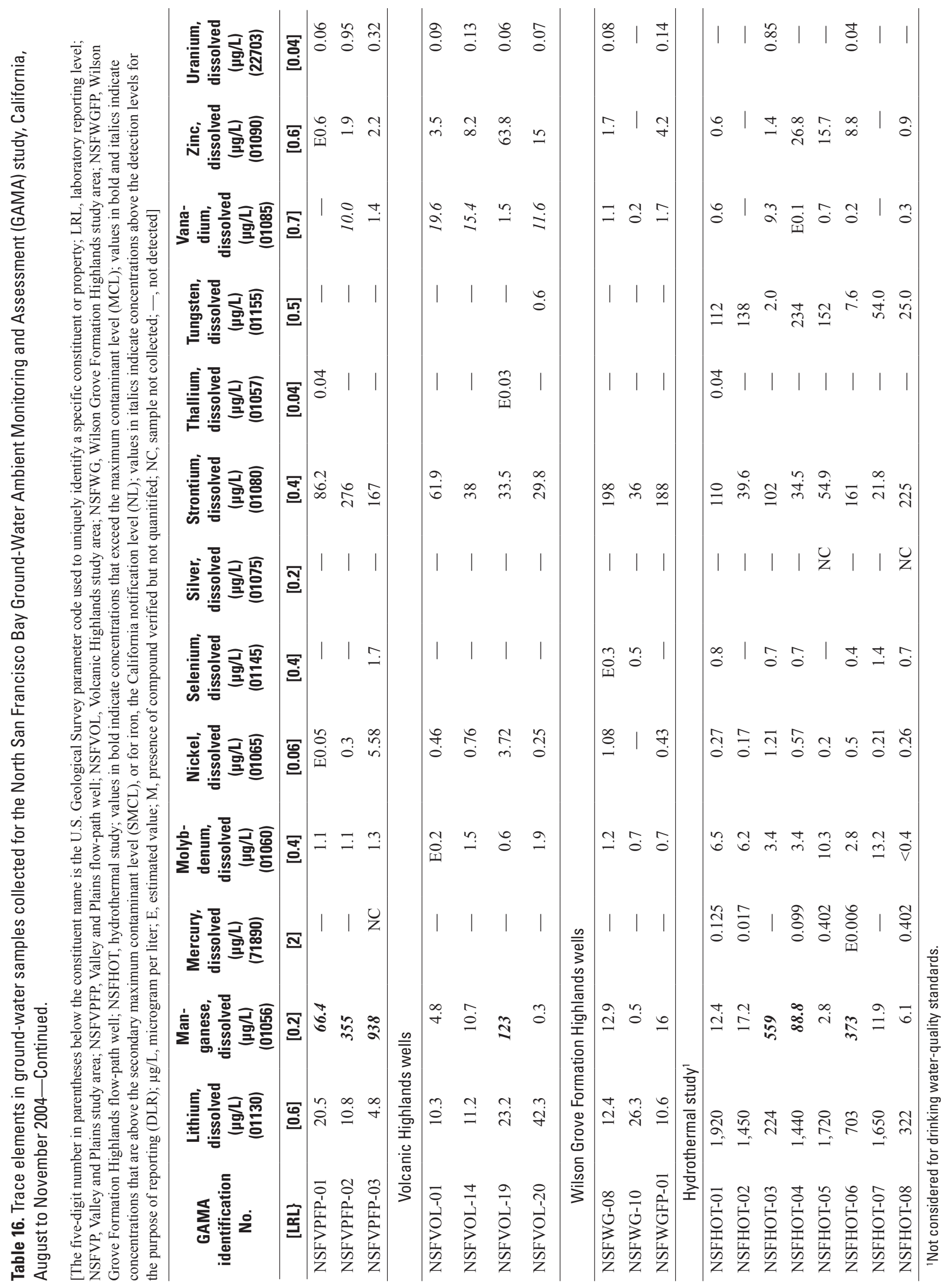


Table 17. Inorganic arsenic and iron-speciation results measured at the U.S. Geological Survey National Research Program in groundwater samples collected for the North San Francisco Bay Ground-Water Ambient Monitoring and Assessment (GAMA) study, California, August to November 2004.

[MDL, method detection limit; NSFVP, Valley and Plains study area; NSFVPFP, Valley and Plains flow-path well; NSFVOL, Volcanic Highlands study area; NSFWG, Wilson Grove Formation Highlands study area; NSFWG, Wilson Grove Formation Highlands flow-path well; NSFHOT, hydrothermal study; values in bold indicate concentrations that exceed the maximum oontaminant level (MCL); values in bold and italics indicate concentrations that are above the secondary maximum contaminant level (SMCL), or for iron, the California notification level (NL); $\mu \mathrm{g} / \mathrm{L}$, microgram per liter; -, not detected]

\begin{tabular}{|c|c|c|c|c|}
\hline $\begin{array}{c}\text { GAMA } \\
\text { identification } \\
\text { No. }\end{array}$ & $\begin{array}{c}\text { Arsenic, } \\
\text { dissolved } \\
(\mu \mathrm{g} / \mathrm{L})\end{array}$ & $\begin{array}{c}\text { Arsenic (III), } \\
\text { dissolved } \\
(\mu \mathrm{g} / \mathrm{L})\end{array}$ & $\begin{array}{c}\text { Iron, } \\
\text { dissolved } \\
(\mu \mathrm{g} / \mathrm{L})\end{array}$ & $\begin{array}{c}\text { Iron (II), } \\
\text { dissolvec } \\
(\mu \mathrm{g} / \mathrm{L})\end{array}$ \\
\hline [MDL] & {$[0.5]$} & [1] & [1] & [1] \\
\hline \multicolumn{5}{|c|}{ Valley and Plains wells } \\
\hline NSFVP-10 & - & - & - & - \\
\hline NSFVP-19 & - & - & 10 & 8 \\
\hline NSFVP-29 & - & - & - & - \\
\hline NSFVP-30 & - & - & 11 & 8 \\
\hline NSFVP-34 & 7.7 & 6.7 & 900 & 860 \\
\hline NSFVP-37 & 3.1 & - & 2 & - \\
\hline NSFVP-38 & 16.2 & 2.8 & 9 & 7 \\
\hline NSFVP-40 & - & - & 301 & 277 \\
\hline NSFVP-45 & 29.8 & 25.1 & 122 & 91 \\
\hline NSFVP-46 & - & - & 19 & 15 \\
\hline NSFVP-49 & 22.0 & 22.0 & 313 & 313 \\
\hline NSFVP-50 & 7.2 & - & 50 & 34 \\
\hline NSFVPFP-01 & 1.2 & - & 36 & 30 \\
\hline NSFVPFP-02 & 2.1 & - & 2 & - \\
\hline \multicolumn{5}{|c|}{ Volcanic Highlands wells } \\
\hline NSFVOL-01 & 1.5 & - & 68 & 58 \\
\hline NSFVOL-05 & 1.6 & - & 12 & 5 \\
\hline NSFVOL-14 & 7.0 & - & 2 & 2 \\
\hline NSFVOL-19 & 1.2 & 1.1 & 180 & 179 \\
\hline NSFVOL-20 & 5.7 & - & 2 & - \\
\hline \multicolumn{5}{|c|}{ Wilson Grove Formation Highlands wells } \\
\hline NSFWG-08 & 12.0 & 3.4 & 37 & 7 \\
\hline NSFWG-10 & - & - & 19 & - \\
\hline NSFWGFP-01 & 4.5 & - & 28 & 26 \\
\hline \multicolumn{5}{|c|}{ Hydrothermal study ${ }^{1}$} \\
\hline NSFHOT-01 & 35.7 & 36.0 & 41 & 41 \\
\hline NSFHOT-02 & 45.0 & 45.0 & 23 & 23 \\
\hline NSFHOT-03 & 28.1 & 2.5 & 4 & 2 \\
\hline NSFHOT-04 & 53.0 & 53.0 & 247 & 210 \\
\hline NSFHOT-05 & 81.0 & 78.0 & 10 & 10 \\
\hline NSFHOT-06 & 10.0 & 5.6 & 315 & 174 \\
\hline NSFHOT-07 & 4.3 & 3.6 & 31 & 27 \\
\hline
\end{tabular}

${ }^{1}$ Not considered for drinking water-quality standards. 
Table 18. Chromium-speciation results measured by the U.S. Geological Survey National Research Progam for ground-water samples collected for the North San Francisco Bay Ground-Water Ambient Monitoring and Assessment (GAMA) study, California, August to November, 2004.

[MDL, method detection limit; NSFVP, Valley and Plains study area; NSFVPFP, Valley and Plains flow-path well; NSFVOL, Volcanic Highlands study area; NSFWG, Wilson Grove Formation Highlands study area; NSFWGFP, Wilson Grove Formation Highlands flow-path well; NSFHOT, hydrothermal study; values in italics indicate concentrations above the detection levels for the purpose of reporting (DLR); $\mu \mathrm{g} / \mathrm{L}$, microgram per liter; —, not detected]

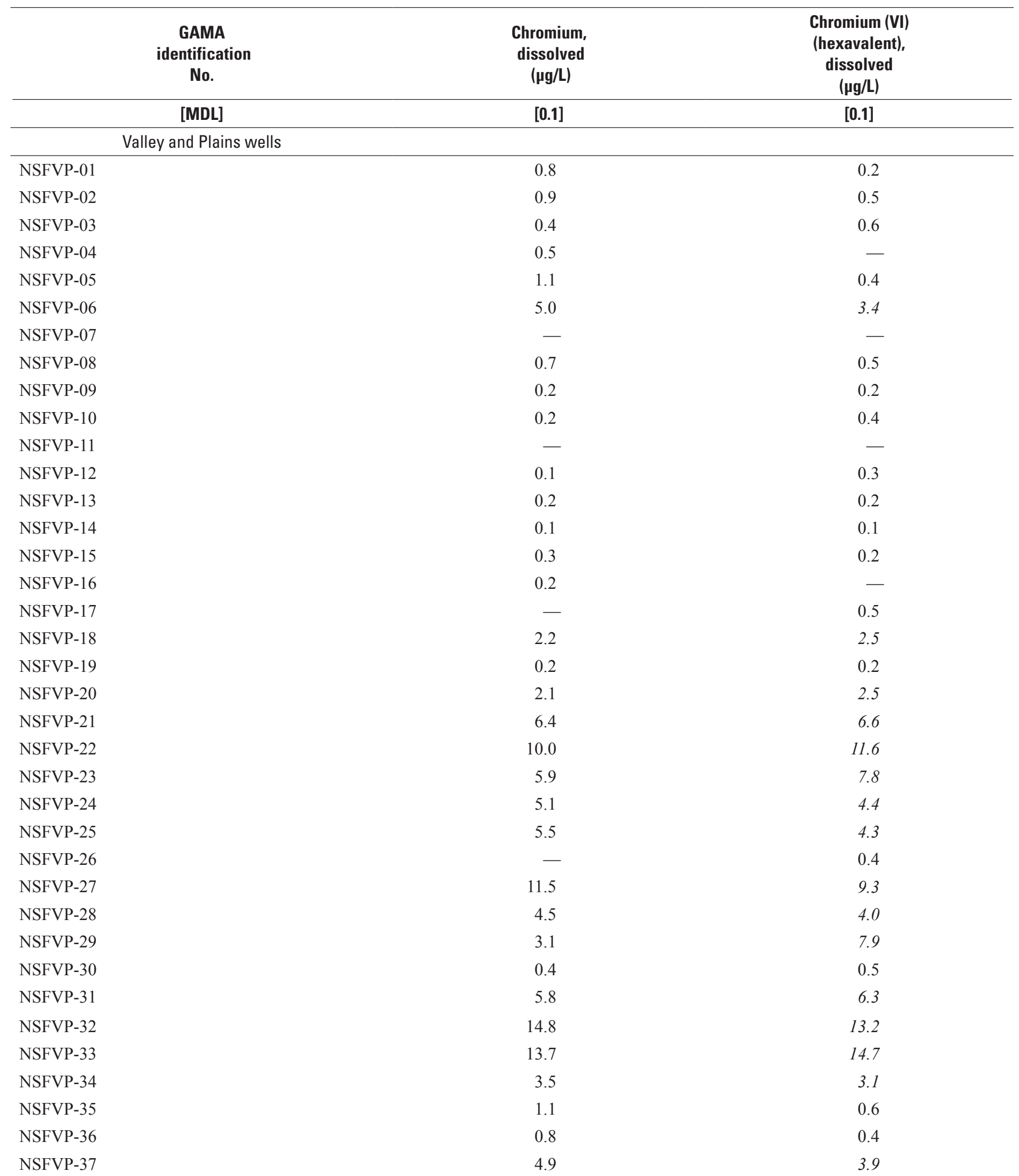


Table 18. Chromium speciation results measured by the U.S. Geological Survey National Research Progam for ground-water samples collected for the North San Francisco Bay Ground-Water Ambient Monitoring and Assessment (GAMA) study, California, August to November, 2004-Continued.

[MDL, method detection limit; NSFVP, Valley and Plains study area; NSFVPFP, Valley and Plains flow-path well; NSFVOL, Volcanic Highlands study area; NSFWG, Wilson Grove Formation Highlands study area; NSFWGFP, Wilson Grove Formation Highlands flow-path well; NSFHOT, hydrothermal study; values in italics indicate concentrations above the detection levels for the purpose of reporting (DLR); $\mu \mathrm{g} / \mathrm{L}$, microgram per liter; —, not detected]

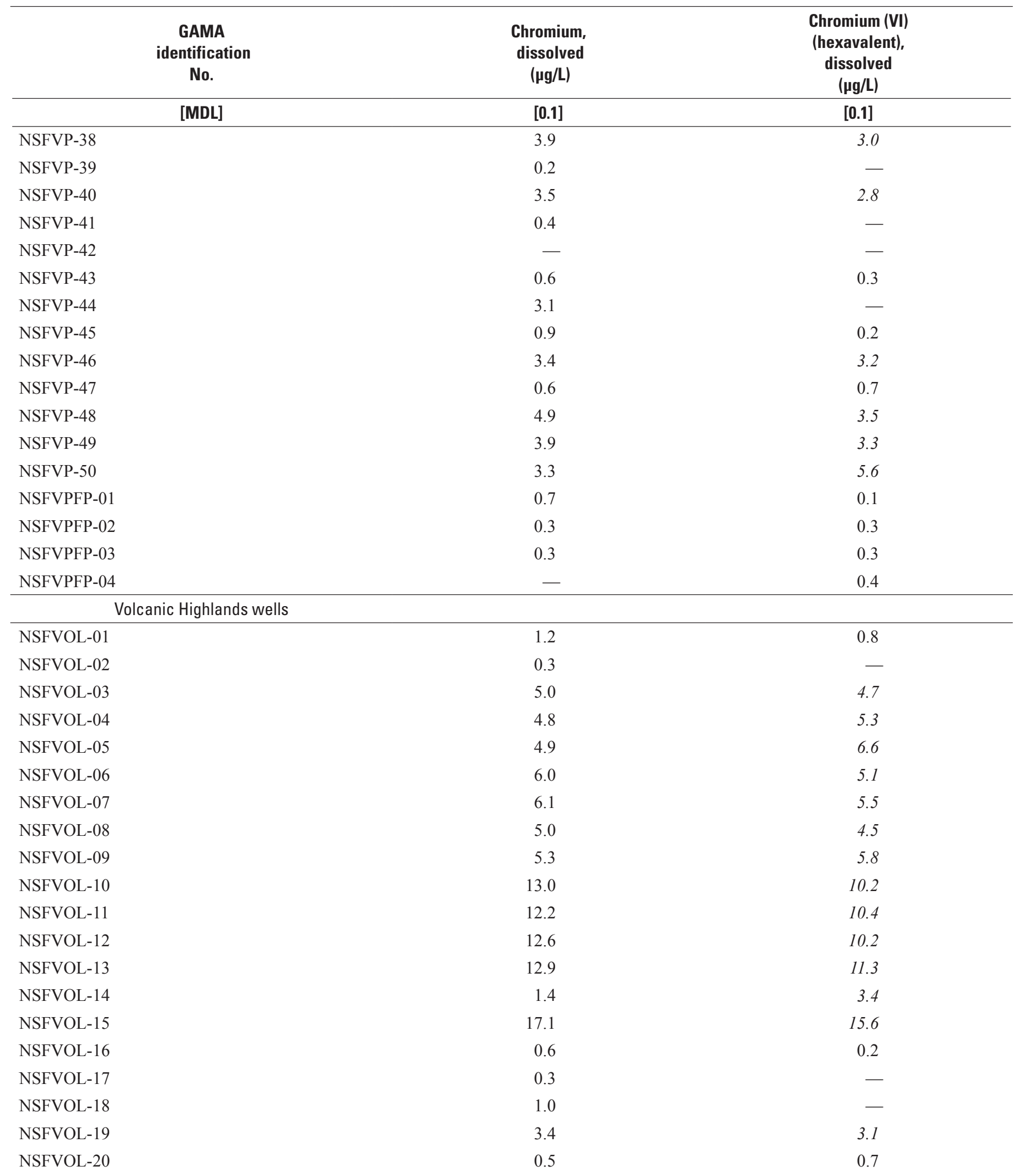


Table 18. Chromium speciation results measured by the U.S. Geological Survey National Research Progam for ground-water samples collected for the North San Francisco Bay Ground-Water Ambient Monitoring and Assessment (GAMA) study, California, August to November, 2004-Continued.

[MDL, method detection limit; NSFVP, Valley and Plains study area; NSFVPFP, Valley and Plains flow-path well; NSFVOL, Volcanic Highlands study area; NSFWG, Wilson Grove Formation Highlands study area; NSFWGFP, Wilson Grove Formation Highlands flow-path well; NSFHOT, hydrothermal study; values in italics indicate concentrations above the detection levels for the purpose of reporting (DLR); $\mu \mathrm{g} / \mathrm{L}$, microgram per liter; —, not detected]

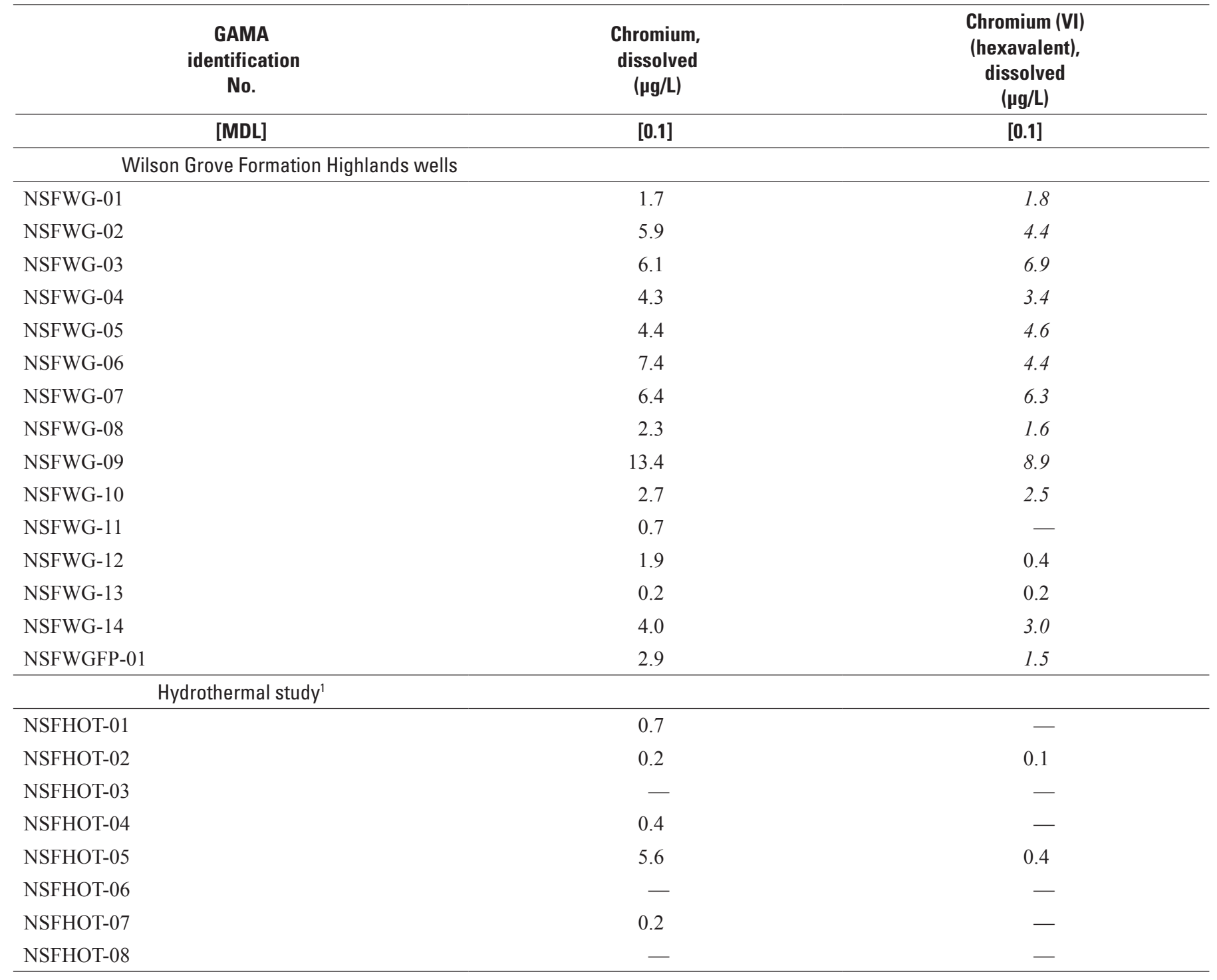

\footnotetext{
${ }^{1}$ Not considered for drinking water-quality standards.
} 
Table 19. Isotopes and radioactivity measured in ground-water samples collected for the North San Francisco Bay Ground-Water Ambient Monitoring and Assessment (GAMA) study, California, August to November 2004.

[The five-digit number in parentheses below the constituent name is the U.S. Geological Survey parameter code used to uniquely identify a specific constituent or property; LRL, laboratory reporting level; NSFVP, Valley and Plains study area; NSFVPFP, Valley and Plains flow-path well; NSFVOL, Volcanic Highlands study area; NSFWG, Wilson Grove Formation Highlands study area; NSFWGFP, Wilson Grove Formation Highlands flow-path well; NSFHOT,

hydrothermal study; values in bold indicate concentrations that exceed the proposed maximum contaminant level (MCL); pCi/L, picocuries per liter; $\mathrm{NC}$, sample not collected; <, less than; - , not detected]

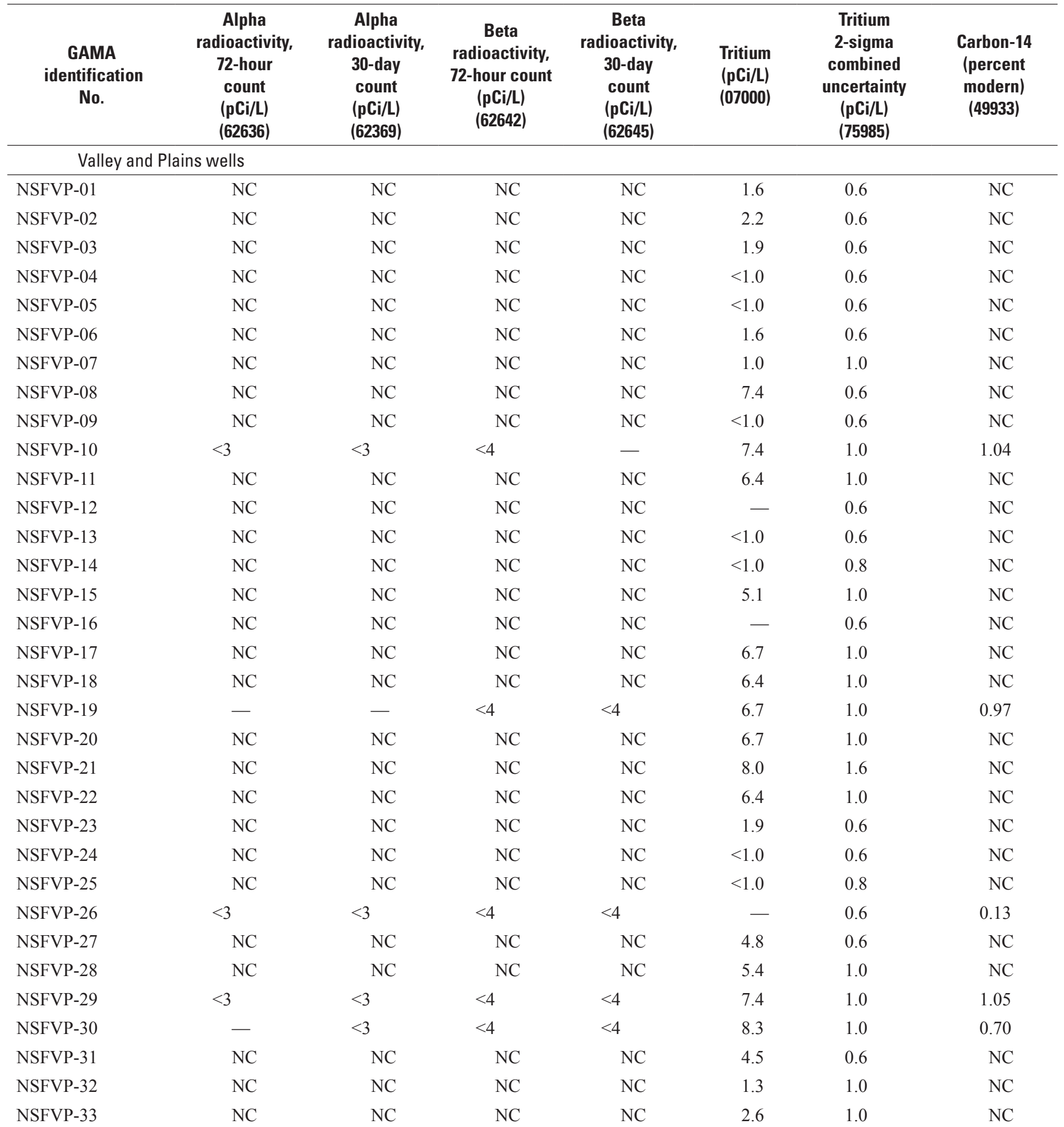


Table 19. Isotope and radioactivity measured in ground-water samples collected for the North San Francisco Bay Ground-Water Ambient Monitoring and Assessment (GAMA) study, California, August to November 2004—Continued.

[The five-digit number in parentheses below the constituent name is the U.S. Geological Survey parameter code used to uniquely identify a specific constituent or property; LRL, laboratory reporting level; NSFVP, Valley and Plains study area; NSFVPFP, Valley and Plains flow-path well; NSFVOL, Volcanic Highlands study area; NSFWG, Wilson Grove Formation Highlands study area; NSFWGFP, Wilson Grove Formation Highlands flow-path well; NSFHOT,

hydrothermal study; values in bold indicate concentrations that exceed the proposed maximum contaminant level (MCL); pCi/L, picocuries per liter; NC, sample not collected; <, less than; - , not detected]

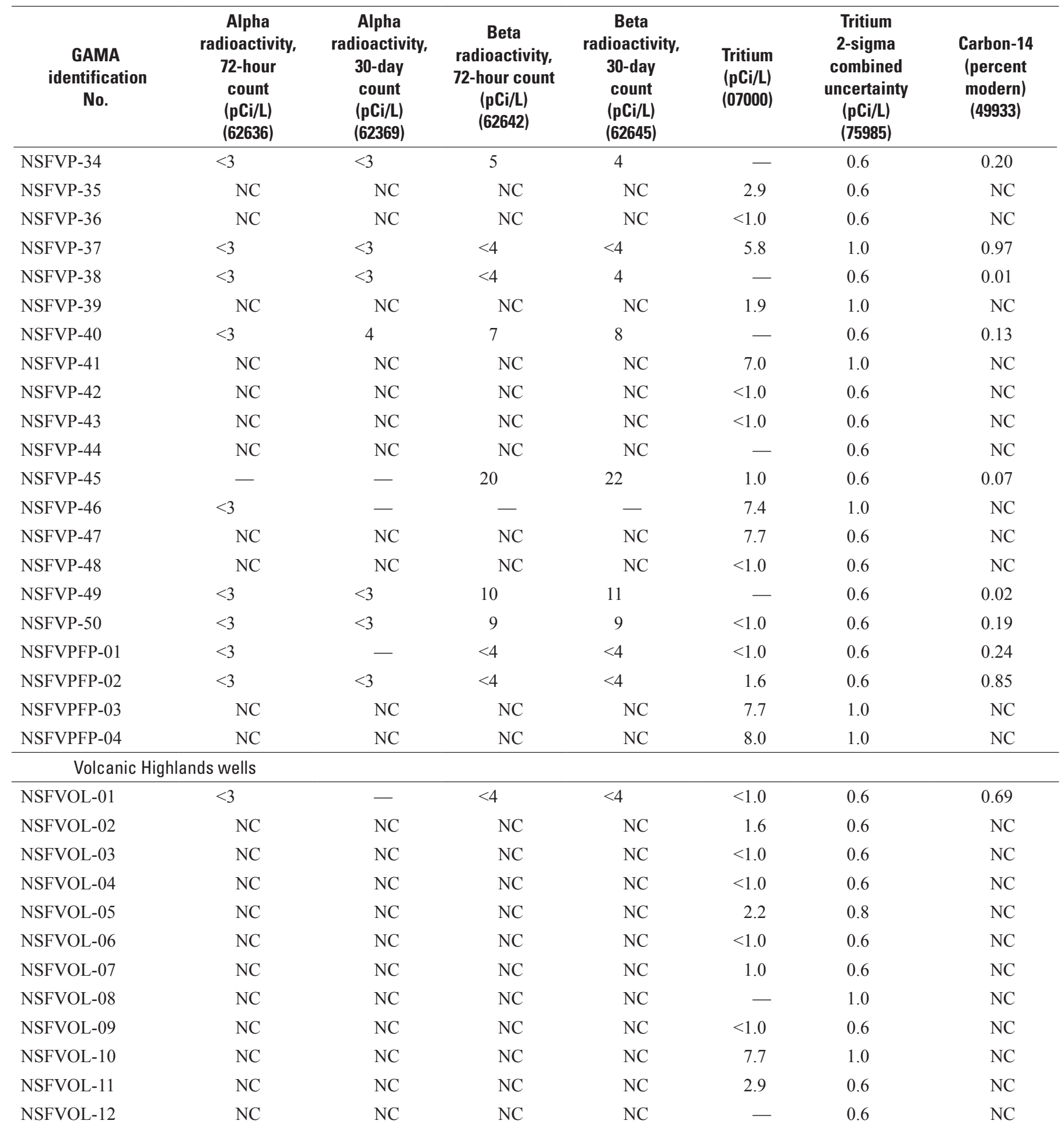


Table 19. Isotope and radioactivity measured in ground-water samples collected for the North San Francisco Bay Ground-Water Ambient Monitoring and Assessment (GAMA) study, California, August to November 2004—Continued.

[The five-digit number in parentheses below the constituent name is the U.S. Geological Survey parameter code used to uniquely identify a specific constituent or property; LRL, laboratory reporting level; NSFVP, Valley and Plains study area; NSFVPFP, Valley and Plains flow-path well; NSFVOL, Volcanic Highlands study area; NSFWG, Wilson Grove Formation Highlands study area; NSFWGFP, Wilson Grove Formation Highlands flow-path well; NSFHOT,

hydrothermal study; values in bold indicate concentrations that exceed the proposed maximum contaminant level (MCL); pCi/L, picocuries per liter; $\mathrm{NC}$, sample not collected; <, less than; - , not detected]

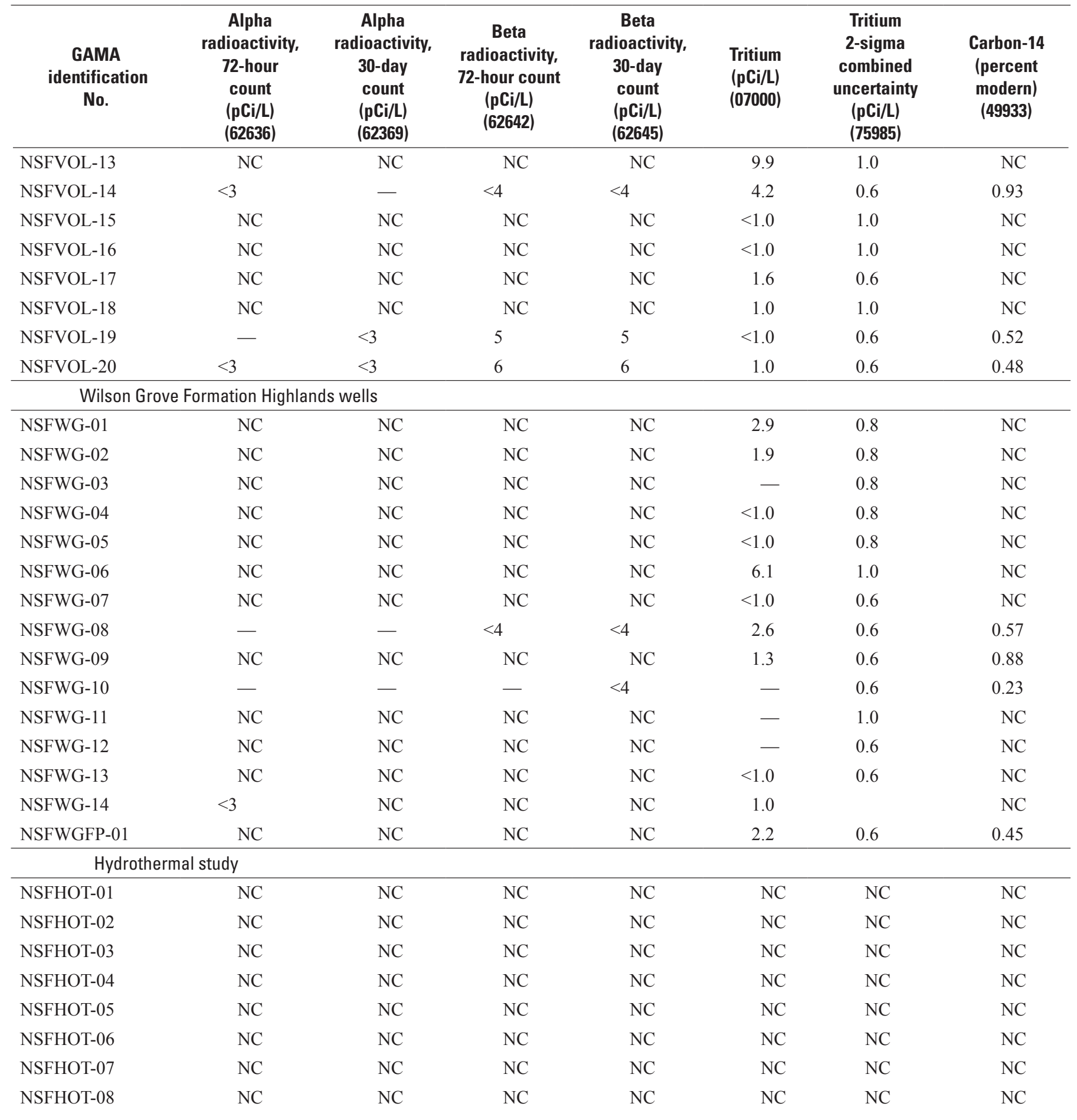


Table 19. Isotope and radioactivity measured in ground-water samples collected for the North San Francisco Bay Ground-Water Ambient Monitoring and Assessment (GAMA) study, California, August to November 2004—Continued.

[The five-digit number in parentheses below the constituent name is the U.S. Geological Survey parameter code used to uniquely identify a specific constituent or property; LRL, laboratory reporting level; NSFVP, Valley and Plains study area; NSFVPFP, Valley and Plains flow-path well; NSFVOL, Volcanic Highlands study area; NSFWG, Wilson Grove Formation Highlands study area; NSFWGFP, Wilson Grove Formation Highlands flow-path well; NSFHOT,

hydrothermal study; values in bold indicate concentrations that exceed the proposed maximum contaminant level (MCL); pCi/L, picocuries per liter; NC, sample not collected; <, less than; - , not detected]

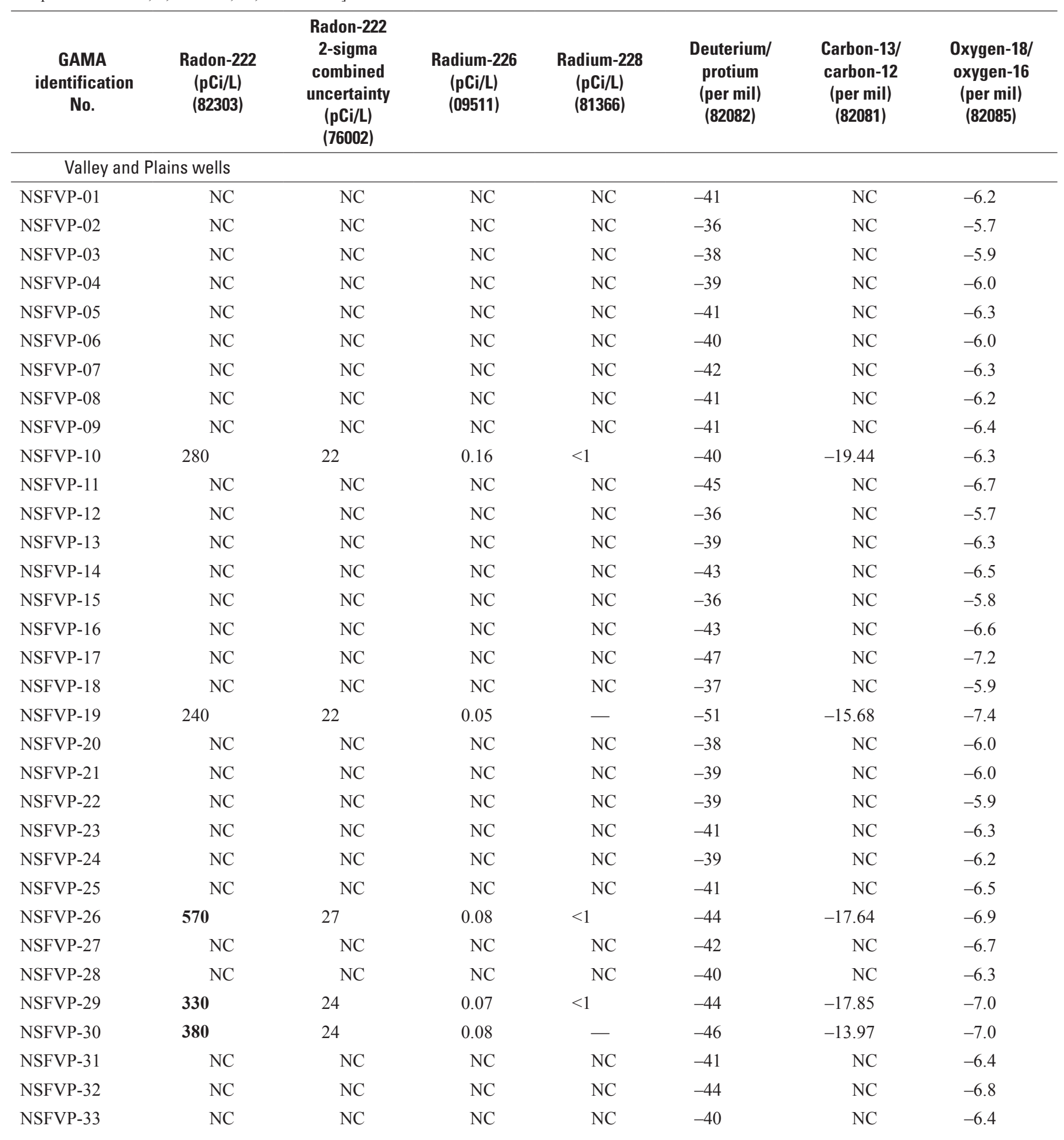


Table 19. Isotope and radioactivity measured in ground-water samples collected for the North San Francisco Bay Ground-Water Ambient Monitoring and Assessment (GAMA) study, California, August to November 2004—Continued.

[The five-digit number in parentheses below the constituent name is the U.S. Geological Survey parameter code used to uniquely identify a specific constituent or property; LRL, laboratory reporting level; NSFVP, Valley and Plains study area; NSFVPFP, Valley and Plains flow-path well; NSFVOL, Volcanic Highlands study area; NSFWG, Wilson Grove Formation Highlands study area; NSFWGFP, Wilson Grove Formation Highlands flow-path well; NSFHOT,

hydrothermal study; values in bold indicate concentrations that exceed the proposed maximum contaminant level (MCL); pCi/L, picocuries per liter; $\mathrm{NC}$, sample not collected; $<$, less than; - , not detected]

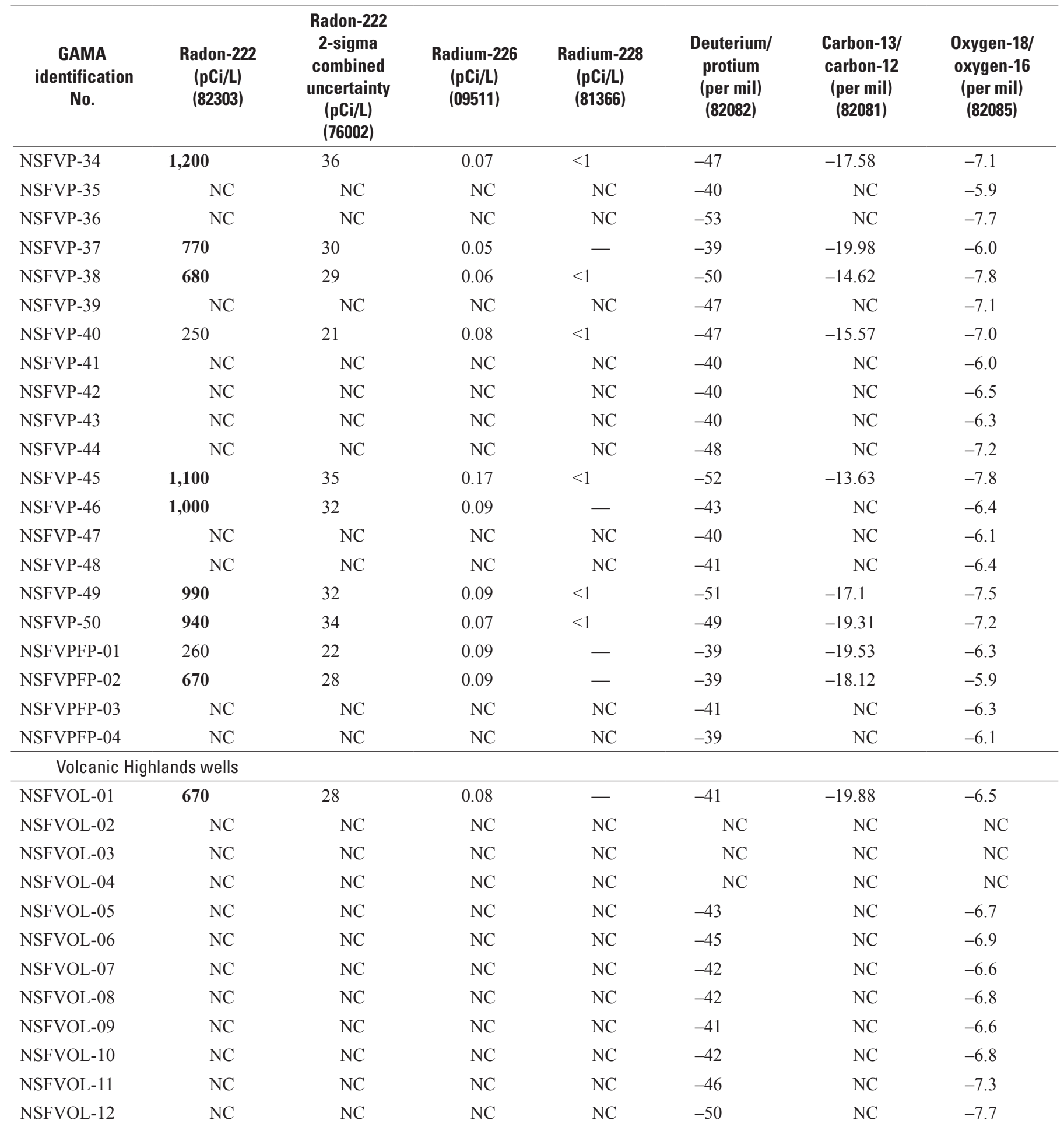


Table 19. Isotope and radioactivity measured in ground-water samples collected for the North San Francisco Bay Ground-Water Ambient Monitoring and Assessment (GAMA) study, California, August to November 2004—Continued.

[The five-digit number in parentheses below the constituent name is the U.S. Geological Survey parameter code used to uniquely identify a specific constituent or property; LRL, laboratory reporting level; NSFVP, Valley and Plains study area; NSFVPFP, Valley and Plains flow-path well; NSFVOL, Volcanic Highlands study area; NSFWG, Wilson Grove Formation Highlands study area; NSFWGFP, Wilson Grove Formation Highlands flow-path well; NSFHOT,

hydrothermal study; values in bold indicate concentrations that exceed the proposed maximum contaminant level (MCL); pCi/L, picocuries per liter; NC, sample not collected; <, less than; - , not detected]

\begin{tabular}{|c|c|c|c|c|c|c|c|}
\hline $\begin{array}{c}\text { GAMA } \\
\text { identification } \\
\text { No. }\end{array}$ & $\begin{array}{c}\text { Radon-222 } \\
(\mathrm{pCi} / \mathrm{L}) \\
(82303)\end{array}$ & $\begin{array}{c}\text { Radon-222 } \\
\text { 2-sigma } \\
\text { combined } \\
\text { uncertainty } \\
\text { (pCi/L) } \\
(76002)\end{array}$ & $\begin{array}{c}\text { Radium-226 } \\
\text { (pCi/L) } \\
(09511)\end{array}$ & $\begin{array}{c}\text { Radium-228 } \\
\text { (pCi/L) } \\
(\mathbf{8 1 3 6 6 )}\end{array}$ & $\begin{array}{c}\text { Deuterium/ } \\
\text { protium } \\
\text { (per mil) } \\
\text { (82082) }\end{array}$ & $\begin{array}{c}\text { Carbon-13/ } \\
\text { carbon-12 } \\
\text { (per mil) } \\
(82081)\end{array}$ & $\begin{array}{c}\text { Oxygen-18/ } \\
\text { oxygen-16 } \\
\text { (per mil) } \\
\text { (82085) }\end{array}$ \\
\hline NSFVOL-13 & $\mathrm{NC}$ & $\mathrm{NC}$ & $\mathrm{NC}$ & $\mathrm{NC}$ & -34 & $\mathrm{NC}$ & -4.5 \\
\hline NSFVOL-14 & 400 & 23 & 0.07 & $<1$ & -40 & -17.6 & -6.1 \\
\hline NSFVOL-15 & $\mathrm{NC}$ & $\mathrm{NC}$ & $\mathrm{NC}$ & $\mathrm{NC}$ & -45 & $\mathrm{NC}$ & -7.2 \\
\hline NSFVOL-16 & $\mathrm{NC}$ & $\mathrm{NC}$ & $\mathrm{NC}$ & $\mathrm{NC}$ & -47 & $\mathrm{NC}$ & -7.1 \\
\hline NSFVOL-17 & $\mathrm{NC}$ & $\mathrm{NC}$ & $\mathrm{NC}$ & $\mathrm{NC}$ & -46 & $\mathrm{NC}$ & -7.1 \\
\hline NSFVOL-18 & $\mathrm{NC}$ & $\mathrm{NC}$ & $\mathrm{NC}$ & $\mathrm{NC}$ & -48 & $\mathrm{NC}$ & -7.2 \\
\hline NSFVOL-19 & 670 & 29 & 0.14 & $<1$ & -47 & -13.12 & -7.4 \\
\hline NSFVOL-20 & 1,500 & 39 & 0.10 & $<1$ & -45 & -19.11 & -7.0 \\
\hline \multicolumn{8}{|c|}{ Wilson Grove Formation Highlands wells } \\
\hline NSFWG-01 & $\mathrm{NC}$ & $\mathrm{NC}$ & $\mathrm{NC}$ & $\mathrm{NC}$ & -37 & $\mathrm{NC}$ & -6.2 \\
\hline NSFWG-02 & $\mathrm{NC}$ & $\mathrm{NC}$ & $\mathrm{NC}$ & $\mathrm{NC}$ & -37 & $\mathrm{NC}$ & -5.9 \\
\hline NSFWG-03 & $\mathrm{NC}$ & $\mathrm{NC}$ & $\mathrm{NC}$ & $\mathrm{NC}$ & -37 & $\mathrm{NC}$ & -6.2 \\
\hline NSFWG-04 & $\mathrm{NC}$ & $\mathrm{NC}$ & $\mathrm{NC}$ & $\mathrm{NC}$ & $\mathrm{NC}$ & $\mathrm{NC}$ & $\mathrm{NC}$ \\
\hline NSFWG-05 & $\mathrm{NC}$ & $\mathrm{NC}$ & $\mathrm{NC}$ & $\mathrm{NC}$ & -41 & $\mathrm{NC}$ & -6.7 \\
\hline NSFWG-06 & $\mathrm{NC}$ & $\mathrm{NC}$ & $\mathrm{NC}$ & $\mathrm{NC}$ & -32 & $\mathrm{NC}$ & -5.4 \\
\hline NSFWG-07 & $\mathrm{NC}$ & $\mathrm{NC}$ & $\mathrm{NC}$ & $\mathrm{NC}$ & -44 & $\mathrm{NC}$ & -6.6 \\
\hline NSFWG-08 & 210 & 21 & 0.10 & $<1$ & -38 & -17.99 & -6.1 \\
\hline NSFWG-09 & $\mathrm{NC}$ & $\mathrm{NC}$ & $\mathrm{NC}$ & $\mathrm{NC}$ & -38 & -20.46 & -6.1 \\
\hline NSFWG-10 & 210 & 22 & 0.05 & - & -36 & -18.11 & -5.8 \\
\hline NSFWG-11 & $\mathrm{NC}$ & $\mathrm{NC}$ & $\mathrm{NC}$ & $\mathrm{NC}$ & -37 & $\mathrm{NC}$ & -5.9 \\
\hline NSFWG-12 & $\mathrm{NC}$ & $\mathrm{NC}$ & $\mathrm{NC}$ & $\mathrm{NC}$ & -38 & $\mathrm{NC}$ & -5.9 \\
\hline NSFWG-13 & $\mathrm{NC}$ & $\mathrm{NC}$ & $\mathrm{NC}$ & $\mathrm{NC}$ & -35 & $\mathrm{NC}$ & -5.6 \\
\hline NSFWG-14 & $\mathrm{NC}$ & $\mathrm{NC}$ & $\mathrm{NC}$ & $\mathrm{NC}$ & -35 & $\mathrm{NC}$ & -5.5 \\
\hline NSFWGFP-01 & $\mathrm{NC}$ & $\mathrm{NC}$ & $\mathrm{NC}$ & $\mathrm{NC}$ & -38 & -15.48 & -6.1 \\
\hline \multicolumn{8}{|c|}{ Hydrothermal study } \\
\hline NSFHOT-01 & $\mathrm{NC}$ & $\mathrm{NC}$ & $\mathrm{NC}$ & $\mathrm{NC}$ & -51 & $\mathrm{NC}$ & -7.8 \\
\hline NSFHOT-02 & $\mathrm{NC}$ & $\mathrm{NC}$ & $\mathrm{NC}$ & $\mathrm{NC}$ & -53 & $\mathrm{NC}$ & -8.3 \\
\hline NSFHOT-03 & $\mathrm{NC}$ & $\mathrm{NC}$ & $\mathrm{NC}$ & $\mathrm{NC}$ & -41 & $\mathrm{NC}$ & -6.2 \\
\hline NSFHOT-04 & $\mathrm{NC}$ & $\mathrm{NC}$ & $\mathrm{NC}$ & $\mathrm{NC}$ & -54 & $\mathrm{NC}$ & -8.2 \\
\hline NSFHOT-05 & $\mathrm{NC}$ & $\mathrm{NC}$ & $\mathrm{NC}$ & $\mathrm{NC}$ & -53 & $\mathrm{NC}$ & -8.3 \\
\hline NSFHOT-06 & $\mathrm{NC}$ & $\mathrm{NC}$ & $\mathrm{NC}$ & $\mathrm{NC}$ & -42 & $\mathrm{NC}$ & -6.1 \\
\hline NSFHOT-07 & $\mathrm{NC}$ & $\mathrm{NC}$ & $\mathrm{NC}$ & $\mathrm{NC}$ & -52 & $\mathrm{NC}$ & -7.6 \\
\hline NSFHOT-08 & $\mathrm{NC}$ & $\mathrm{NC}$ & $\mathrm{NC}$ & $\mathrm{NC}$ & -51 & $\mathrm{NC}$ & -7.5 \\
\hline
\end{tabular}




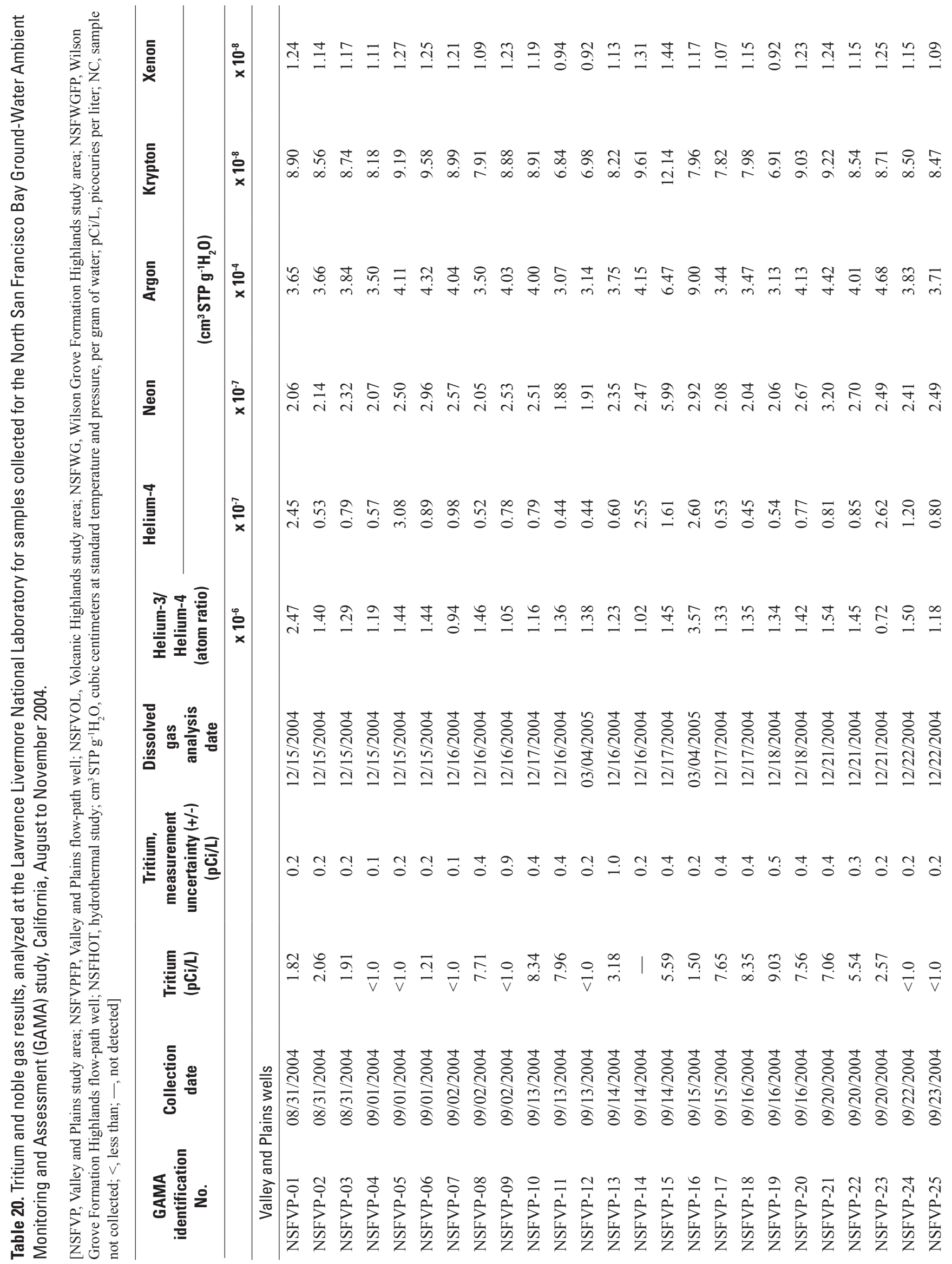




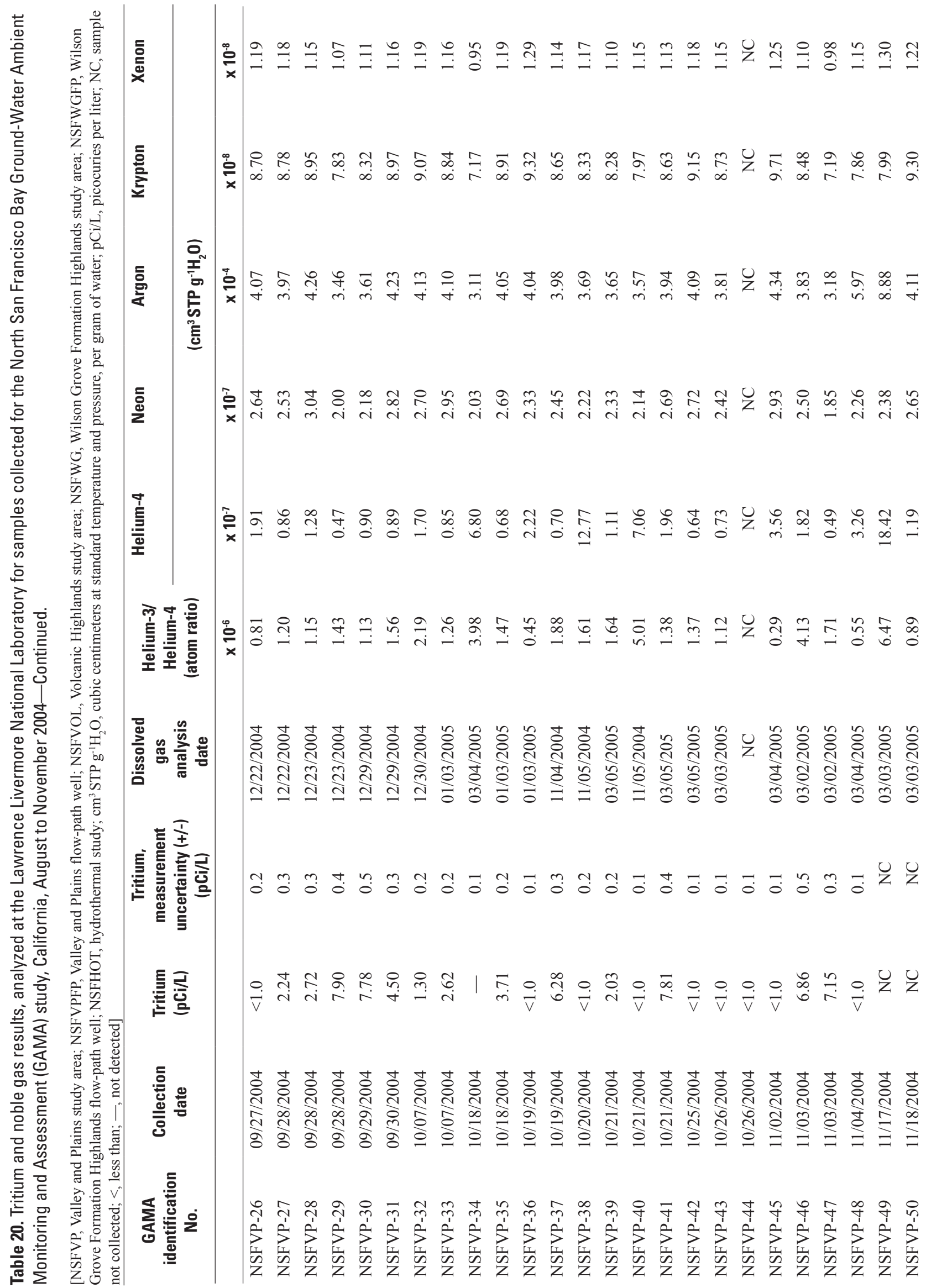




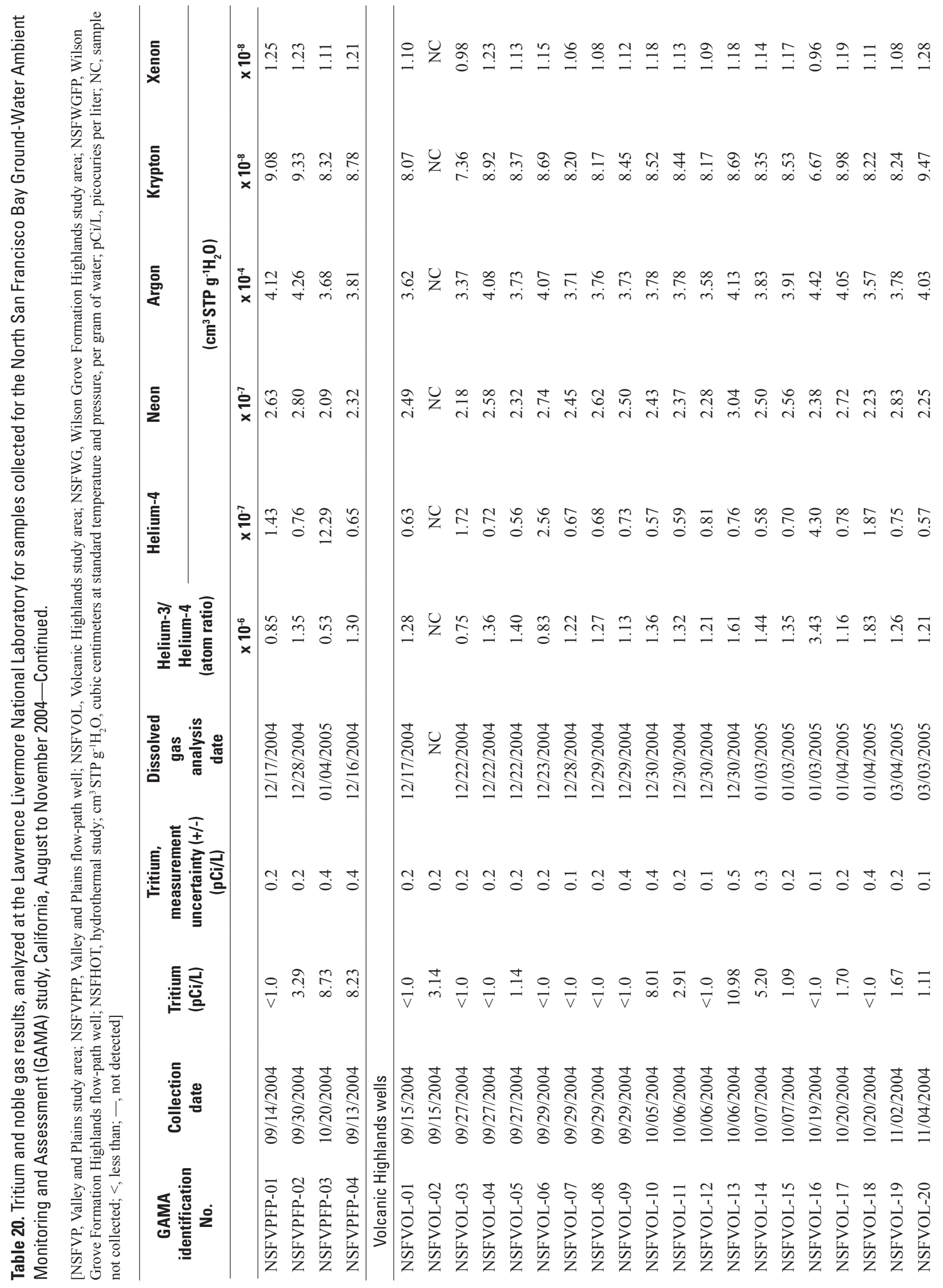




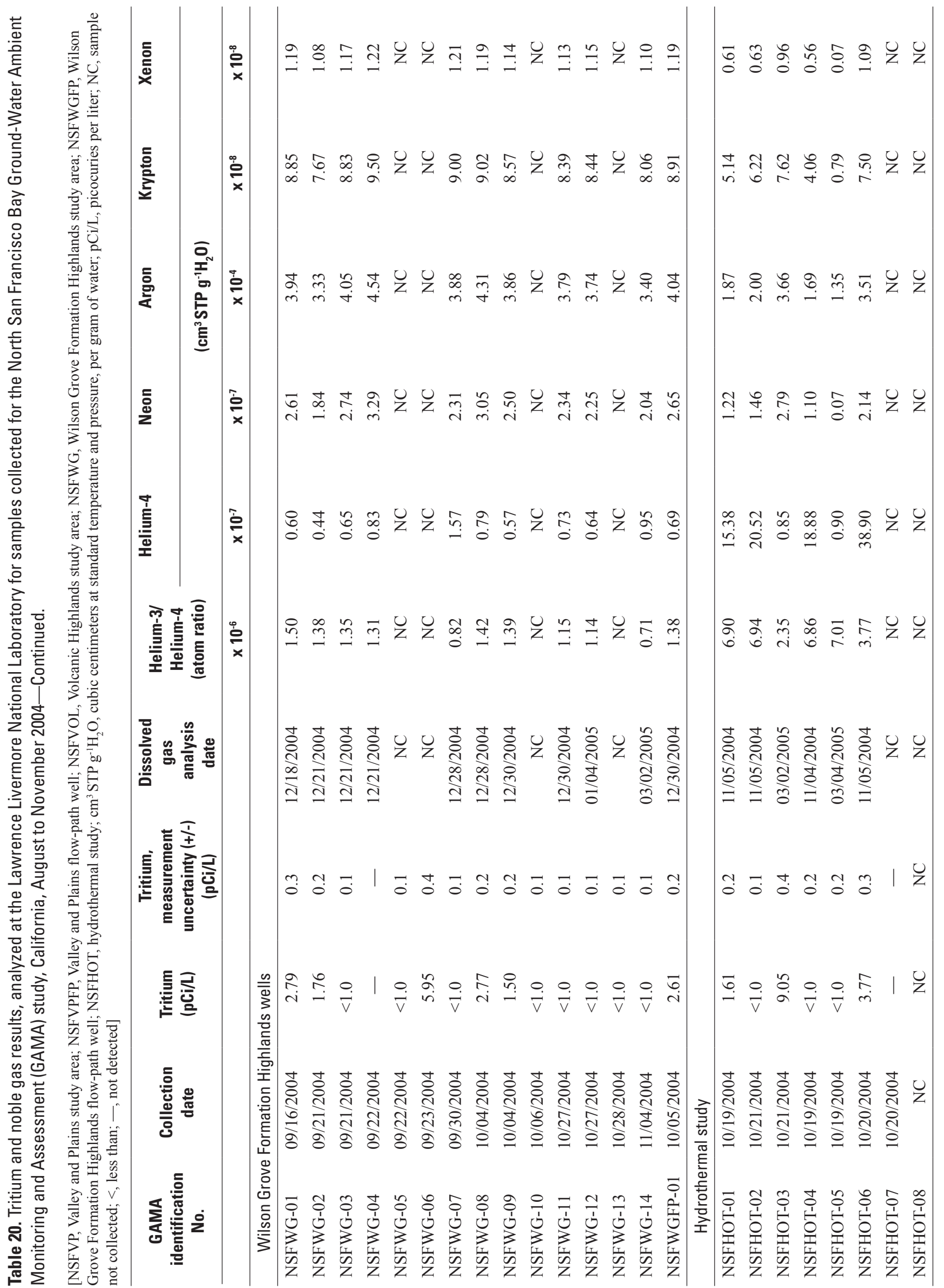


Table 21. Concentrations of the dissolved gases: carbon dioxide, nitrogen, argon, oxygen, and methane analyzed at Lawrence Livermore National Laboratory in samples collected for the North San Francisco Bay Ground-Water Ambient Monitoring and Assessment (GAMA) study, California, August to November 2004.

$\left[\mathrm{cm}^{3}\right.$ STP g-1 $\mathrm{H}_{2} 0$, centimeters cubed at standard temperature and pressure, per gram of water; NSFVP, Valley and Plains study area; NSFHOT, hydrothermal study]

\begin{tabular}{|c|c|c|c|c|c|}
\hline \multirow{3}{*}{$\begin{array}{c}\text { GAMA } \\
\text { identification } \\
\text { No. }\end{array}$} & Carbon dioxide & Nitrogen & Argon & Oxygen & Methane \\
\hline & \multicolumn{5}{|c|}{$\left(\mathrm{cm}^{3} \mathrm{STP} \mathrm{g}^{-1} \mathrm{H}_{2} \mathrm{O}\right)$} \\
\hline & $\times 10^{-2}$ & $\times 10^{-2}$ & $\times 10^{-2}$ & $\times 10^{-2}$ & $\times 10^{-4}$ \\
\hline NSFVP-34 & 35.5 & 4.71 & 4.31 & 1.16 & 0.41 \\
\hline NSFVP-37 & 117 & 6.05 & 5.08 & 2.31 & 0.32 \\
\hline NSFVP-40 & 29.6 & 4.54 & 4.17 & 0.43 & 8.03 \\
\hline \multicolumn{6}{|c|}{ Hydrothermal study } \\
\hline NSFHOT-01 & 14.2 & 1.05 & 1.10 & 0.56 & 44.0 \\
\hline NSFHOT-02 & 22.7 & 1.97 & 1.49 & 0.41 & 97.3 \\
\hline NSFHOT-03 & 283 & 4.75 & 3.86 & 1.42 & 0.66 \\
\hline NSFHOT-07 & 4.94 & 3.41 & 1.89 & 0.71 & 313 \\
\hline
\end{tabular}


Table 22. Microbial analyses of ground-water samples collected for the North San Francisco Bay Ground-Water Ambient Monitoring and Assessment (GAMA) study, California, August to November 2004.

[The five-digit number below the compound name is the U.S. Geological Survey parameter code used to uniquely identify a specific constituent or property. NSFVP, Valley and Plains study area; NSFVPFP, Valley and Plains flow-path well; NSFVOL, Volcanic Highlands study area; NSFWG, Wilson Grove Formation Highlands study area; NSFWGFP, Wilson Grove Formation Highlands flow-path well; ml, milliliter; NR, not reported; - , not detected]

\begin{tabular}{|c|c|c|c|c|}
\hline $\begin{array}{c}\text { GAMA } \\
\text { identification No. }\end{array}$ & $\begin{array}{c}\text { Coliphage } \\
\text { F-specific } \\
\text { (99335) }\end{array}$ & $\begin{array}{l}\text { Coliphage } \\
\text { somatic } \\
\text { (99332) }\end{array}$ & $\begin{array}{c}\text { E. coli } \\
\text { (colonies/ } \\
\text { 100ml) } \\
(90901)\end{array}$ & $\begin{array}{c}\text { Total coliforms } \\
\text { (colonies/100ml) } \\
(90900)\end{array}$ \\
\hline \multicolumn{5}{|c|}{ Valley and Plains wells } \\
\hline NSFVP-10 & - & - & - & - \\
\hline NSFVP-19 & - & - & - & - \\
\hline NSFVP-26 & - & - & - & - \\
\hline NSFVP-29 & - & - & - & - \\
\hline NSFVP-30 & - & - & - & - \\
\hline NSFVP-34 & - & - & - & - \\
\hline NSFVP-37 & - & - & - & - \\
\hline NSFVP-38 & - & - & NR & E2 \\
\hline NSFVP-40 & - & - & - & - \\
\hline NSFVP-45 & - & - & - & - \\
\hline NSFVP-46 & - & - & - & 9 \\
\hline NSFVP-49 & - & - & - & - \\
\hline NSFVP-50 & - & - & - & - \\
\hline NSFVPFP-01 & - & - & - & - \\
\hline NSFVPFP-02 & - & - & - & - \\
\hline \multicolumn{5}{|c|}{ Volcanic Highlands wells } \\
\hline NSFVOL-01 & - & - & - & - \\
\hline NSFVOL-14 & - & - & - & - \\
\hline NSFVOL-19 & - & - & - & - \\
\hline NSFVOL-20 & - & - & - & - \\
\hline \multicolumn{5}{|c|}{ Wilson Grove Highlands Formation wells } \\
\hline NSFWG-08 & - & - & - & - \\
\hline NSFWG-10 & - & - & - & 20 \\
\hline NSFWGFP-01 & - & - & - & - \\
\hline
\end{tabular}

